\title{
أثر استخدام محفزات الألعاب الرقمية في تنمية مهارات تصمييم مواقع الويب ومهارات التفكير البصري لدى تلاميذ الحلقة الإعدادية
}

\begin{abstract}
د م م مد السيد النجار
مدرس تكنولوجيا التعليم والتعلم الاككتروني

كلية الدراسات التربوية- الجامعة المصرية للتعلم الإلكتروني الأهلية

الملخص :

هدف البحث إلى قياس أثر استخدام محفزات الألعاب الرقمية في تتمبية مهارات تصميم مواقع

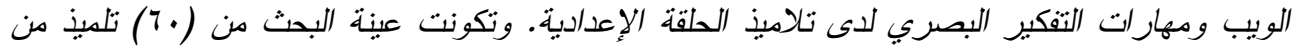

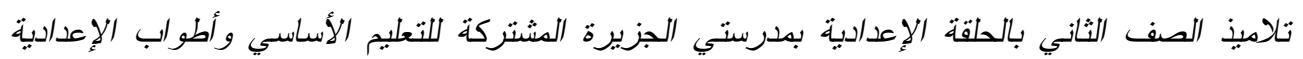

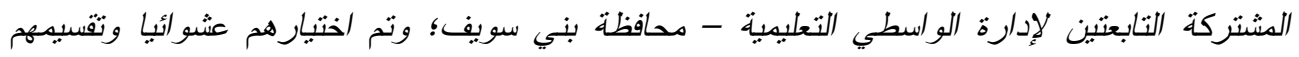

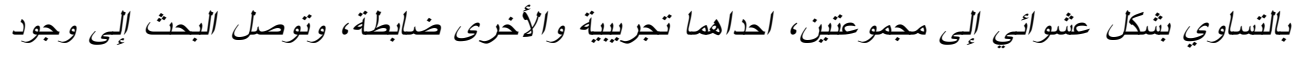

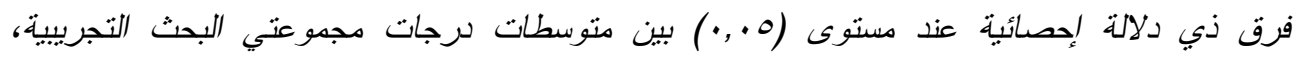

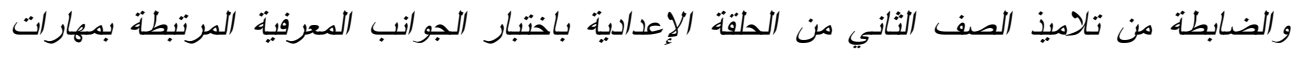

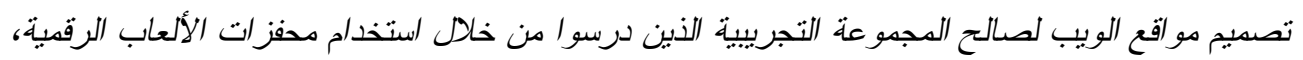

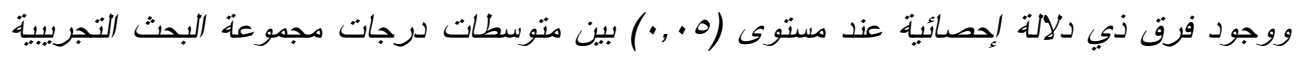

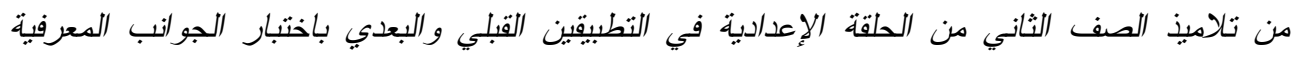

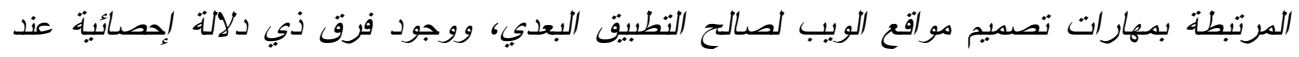

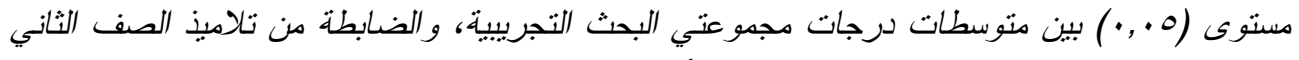

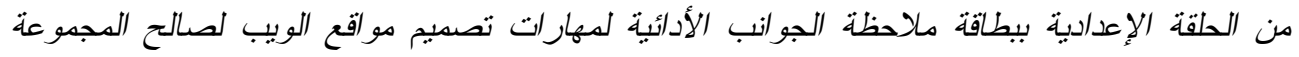

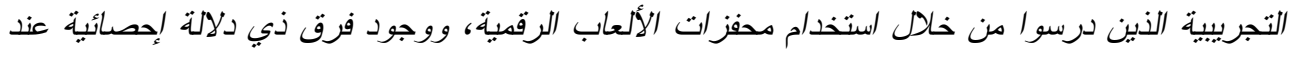

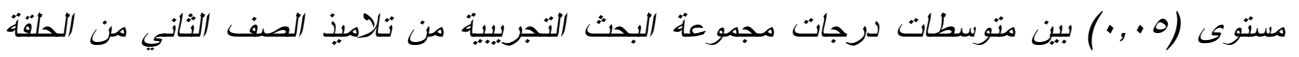

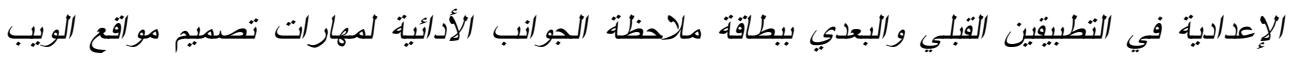

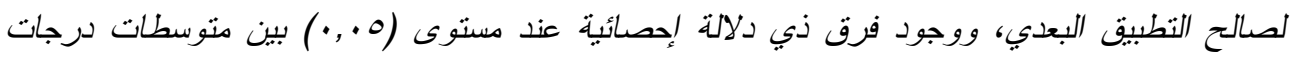

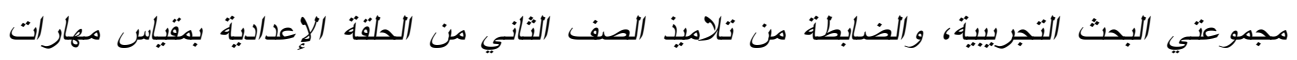

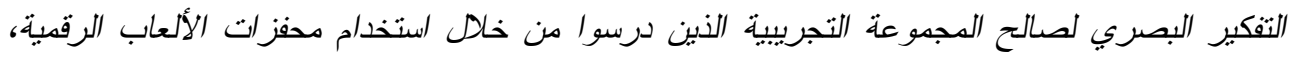

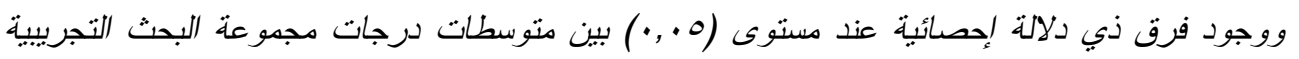

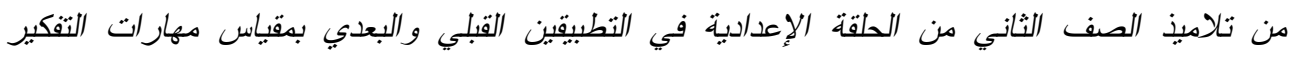

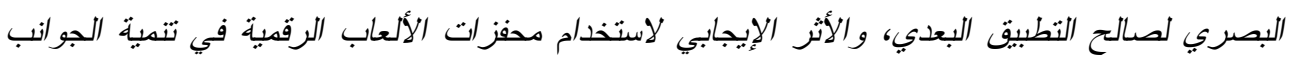

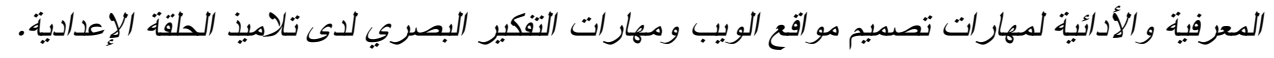
الكلمات المفتاحية: محفزات الألعاب الرقمية ـ مهارات تصميم مواقع الويب ــ مهارات التفكير البصري ميز
\end{abstract}




\section{المقدمة}

الفروق الفردية بينهم، وتعمل علــى تتميــة مهار ات التفكير لايهم، وتدريبهح على حـلـل

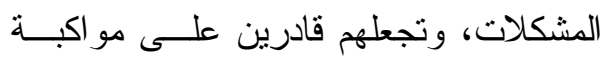
التطورات، ومواجهة التحديات المختلفة التي

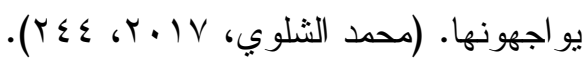
و أصبح على المتعلمين ضرورة صقل مهارتهم وتطوير تعلمهم ليكونو ا قادرين على ولى

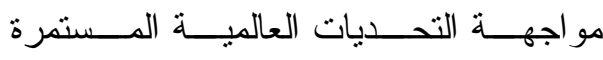
(Saavedra \& Opfer, 2012) استهدف فطاع التعلم فــي (خطــــة التتميـــة

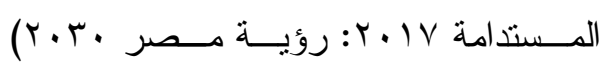
تطوير المناهج بجميع عناصر ها؛ ما يتتاسب

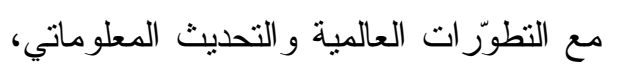
مع مر اعاة سن المتعلّم و احتياجاته البيولوجية ولمنية

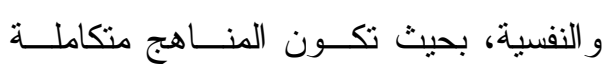
وتُشهم في بناء شخصيته.

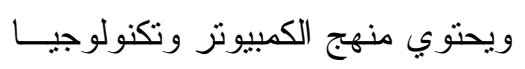
المعلومات بالحلقة الإعدادية على العديد مــن ونـ الموضوعات التي نستطيع من خلالها بنــاء

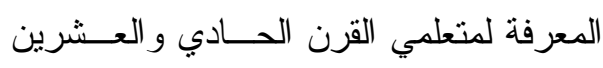
بشكل منطور يو اكب عصر الانفجار الرقمي

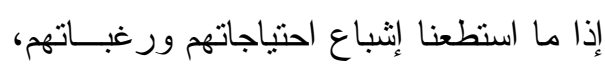

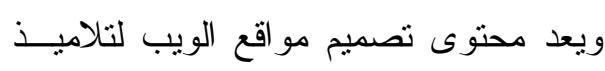
الصف الثاني من الحلقة الإعدادية، من أبرز الموضوعات التي تؤكد على ضرورة بنــاء جيل رقمي مو اكب لمستحدثات التكنولوجيــا؛ فؤل
يشهد العالم ثورة معلوماتية هائلة على لهم

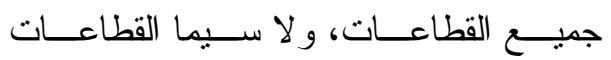

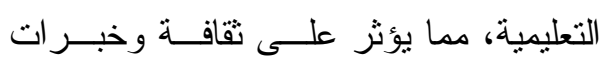

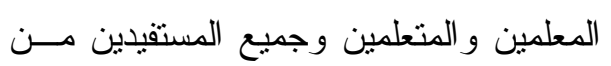

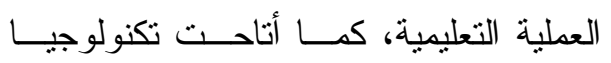
المعلومات و الاتصالات الانفتاح على نافــذة

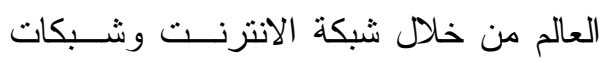
التو اصل الاجتماعي وغير ها من التطبيةــات التي تتيح التو اصل وتبادل الخبر ات و التقافات

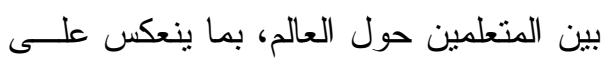

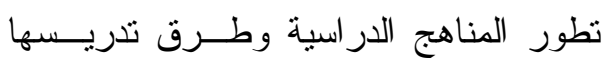

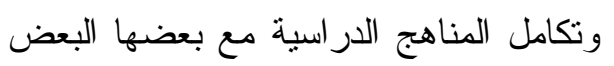
بطرق أكثر فائدة ونفع للمتعلمين.

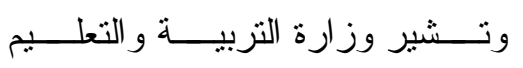

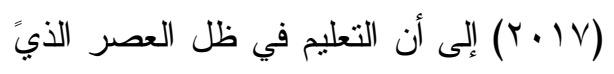

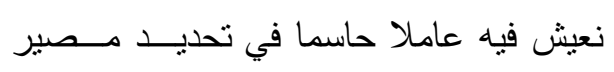

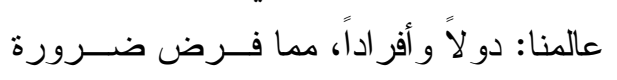
مجار اة المؤسسة التعليمية للتقدم التكنولوجي و العلمي، وقد نتج عن هذا تغيير في معـايير

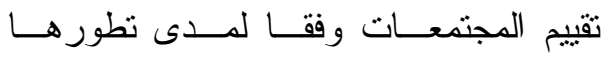
تكنولوجيا، ومعلوماتيا، وقدرتها على التحول

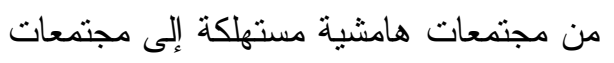
منتجة للمعرفة. مجنمات هات وبالتالي ظهــرت اتجاهــــات حديثــة

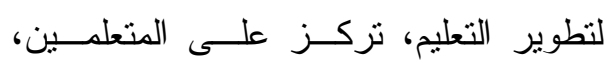
وتجعلهم محور العملية التعليمية، وتراعـي لرئي 
المعلومات في المو اد الدر اسية، ومسـساعدتهم على تتمية القدرة علــى الابتكــار ، و إنتـــاج الأفكار الجديدة (محمد عيد عمار ، ونجـــوان

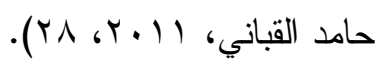

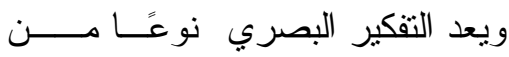

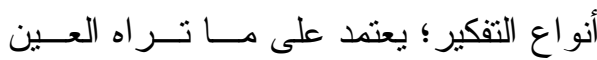

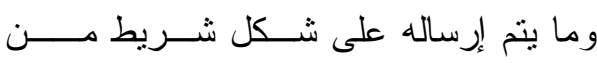
المعلومات المتتابعة الحدوث (المشاهدة) إلى لئ لئل

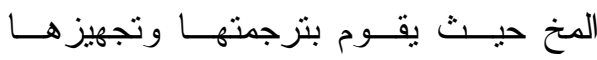

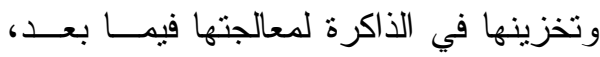
و الجانب الأيسر من المخ هو المسئول عـنـ عمليات معالجة الأفكار المنطقية. أما الجانب الأيمن فهو المسئول عن معالجــة الأفكـــار الإبداعية، و المتميزون في هذا النــوع مــن فئن

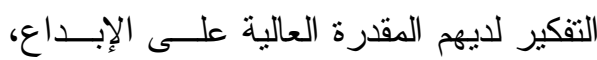

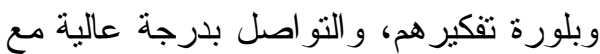
كل من الأفكار و الأشخاص الآخرين. ويطلق عليهم أصحاب الجانب الأيمن مــن المـــن. (أحمد عبد المجيد، r ا • r). و التقكير البصري هو أحد مسـستويات التفكير، و التي تعتمد على الفنون البـصرية

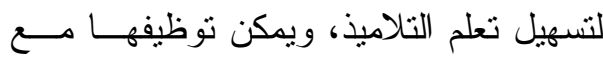
المناقشات الصفية بين المعلم و التلاميذ وبين

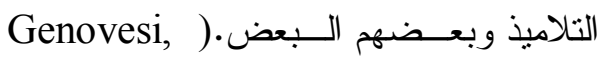
. (2011, 12

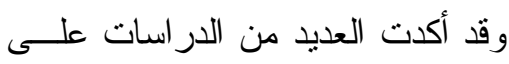
أهمية التفكير البصري في العملية التعليميــة
بحيث يكون المحتوى متمركز ا حول المتعلم، ويعتمد على الأنشطة، قادر ا على الإنتاج وذا فكر منطور مو اكب للعصر.

هذا ويرى الباحث أن هنــــالك أهميـــة لتعليم تلاميذ الحلقة الإعدادية دهار ات تصميم مو اقع الويب؛ و التي بدور ها تساعدهم علــى لإنى

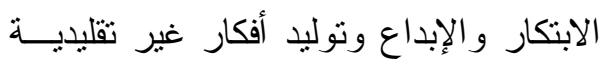
تساعدهم على تفريغ طاقاتهم بشكل إيجـابي ينعكس على مسنو اهم التعليمي و الفكري.

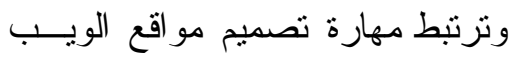

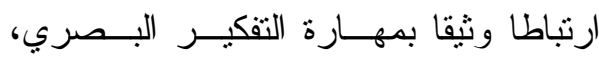
فالتفكير البصري الجيد يساعد على تــصميم

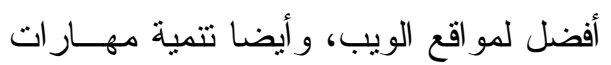

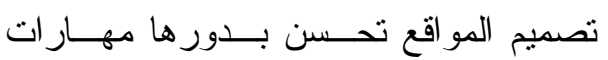
التفكير البصري. ويرى الباحث أن التفكير البصري من المهار ات الهامة و الضرورية لتلاميذ الحلقـــة الإعدادية، حيث أن تلك المهــار ات تـسـاعد على دعم تعلم التلاميذ، وذللك مــن خــله

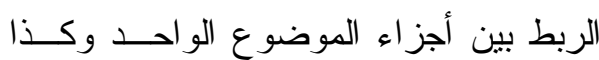
الربط بين الموضوعات المتنوعة من خــلدل

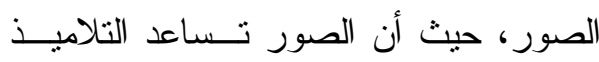
على تذكر المعلومات نتيجة اســتقبالها مــن خلال حاسة البصر مما يدعم من بقاء أثــر التعلم لدى التنلاميذ. وتظهر أهمية التفكير البـصري فـي لتصني

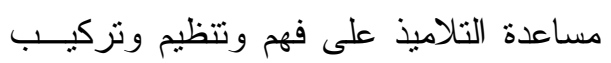


المتعلمين وبدلا من ذلك يحتاج المتعلمون إلى تخــصيص وقتـــا للتفاعـلـ مـــع المعلمــين

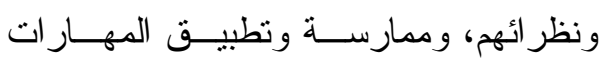
و المعارف التي تم اكتسابها.

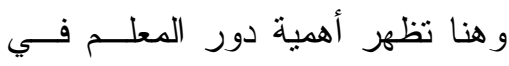

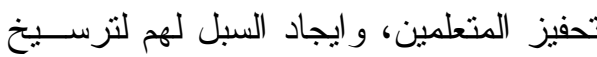
الحافز الجوهري، ويستتد الحافز على نظوير

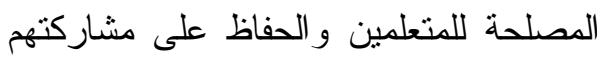
وتتجيع الثقة في قدر اتهم لأداء مهمه معينة.

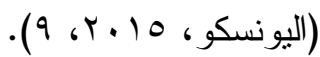
وترى العديد من الأدبيات أن الألعاب

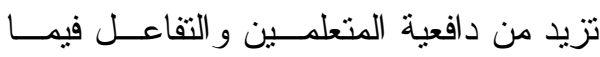
بينهم، عند تقديم المعالجة عن طريق إدمــاج

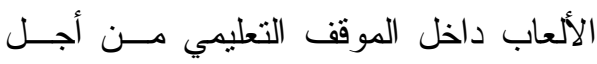

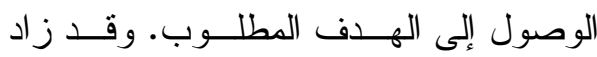

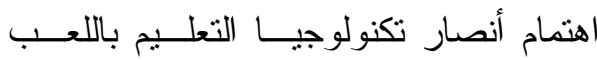

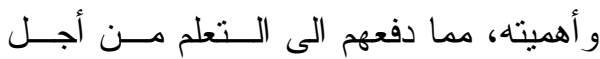

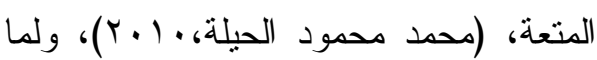
حققته الألعاب من إثارة و تتشويق ومتعة، لذا

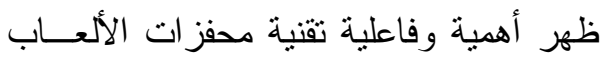

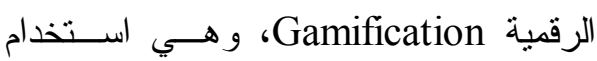

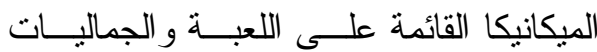
وفكر الألعاب لمشاركة المتعلمين، وتحفيز هم

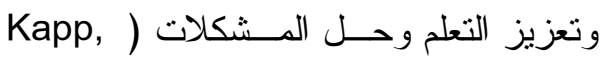
2012)، فعند استخدام هذه الاستر اتيجية في ولمي

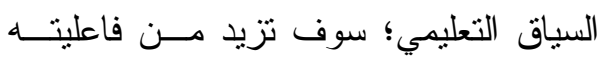

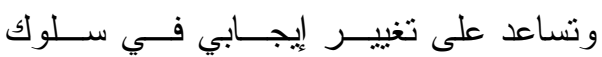

ومنها: در اسة فايزة أحمد حمـادة (T . . T)،

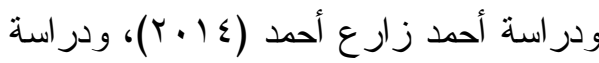

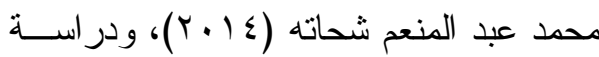

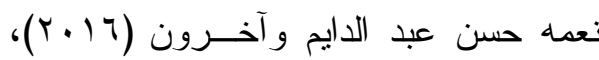

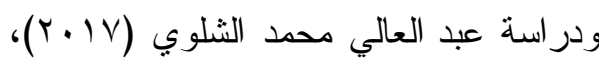
ودر اسة رنا زيلعي البيشي (19 ـ بـ). وتظهــر علاقـــة مهــار ات التفكيــر البصري بمهار ات تصميم مو اقع الويب فــي

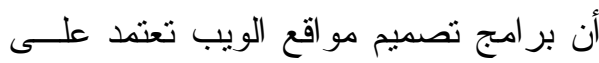

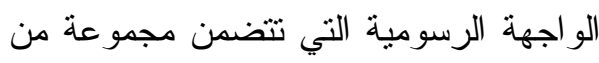

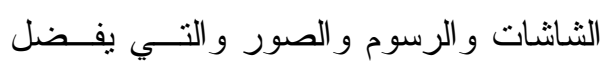

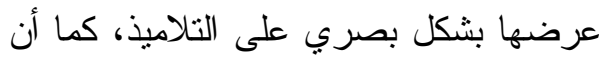

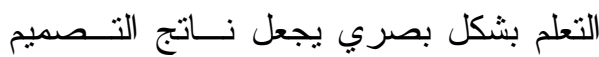
مو اقع وصفحات ويب ذات شـكل جمــالي لئي يساعد مبني في ضو ء رؤية و اضحة، حيــــ

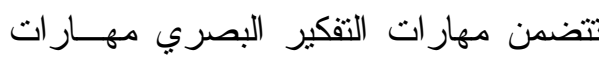
الذاكرة البصرية و الإدر الك البصري و التميز البصري والاتصال البــصري و الاســتـلال

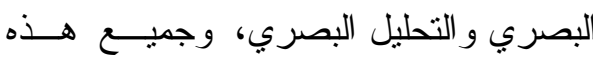
المهار ات ذات علاقة وثثقة بمهار ات تصميم مو اقع الويب ومكوناتها.

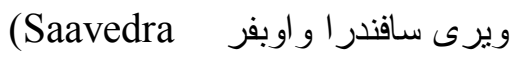
\& Opfer, 2012)

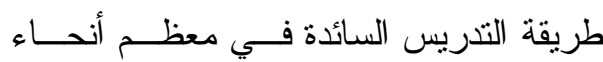

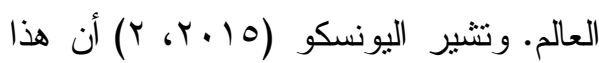
الأسلوب من التشريس يسبب عادة حالة مـنـ

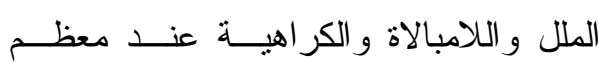


وقد أكدت دراســة كـابونيتو وارب

Caponetto, Earp \& Ott, ) واوت ولهن

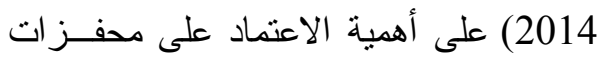

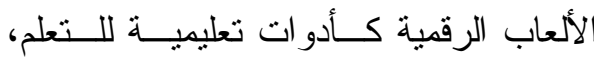
ودر اسة جاكسون (Jackson,2016) التــي أكدت على أهمية دمج محفــزات الألعــاب الرقمية في المناهج الدراسية، ودر اســـة اوره الهية وآخرون (Urh, et al, 2015) التي أكــدت أن استخدام محفز ات الألعاب الرقمية له تأثثير إيجابي على عملية التعلم من خــلال زيــادة

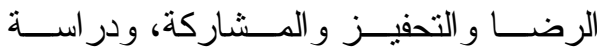

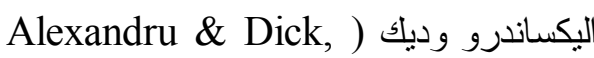
2014) أن محفز ات الألعاب الرقمية ساعدت على جذب انتباه الطلاب، وزيادة مشاركتهم في الأنشطة غير العادية، و المهام الــصعبة ولـادة عنداه

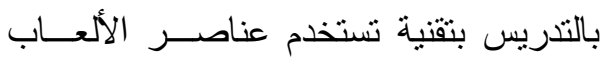
الاجتماعية، ودر اسة ساندوسكي ودر اسة ولي لاسي وهـامر (See \& Sandusky, 2017 (Hammer, 2011 لمحفزات الألعاب الرقمية تأثثير على الفصل

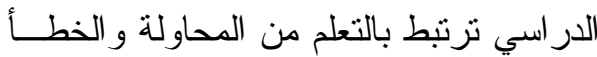

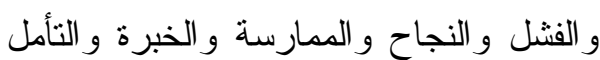
والاتجاه من الدو افع الداخلية للهـتـعلم إلـى ولى ولى ولى

$$
\text { الدو افع الخارجية. }
$$

وقد أكدت دراسة فيلاجر اسا وفونسيكا

وريدونــدو Villagrasa, Fonseca, and Redondo (2014) إلى أن هنــاك علاقـــة
المتعلمين، وتزيد من مشاركتهم ودافعيــتهم

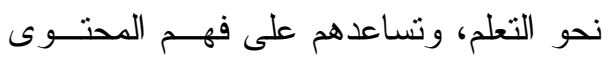

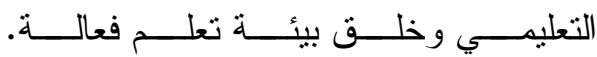
Kiryakova, Angelova \& ) (Yordanova, 2014

ولهذا تسعى هذه التقنيــة التحفيزيـــة الجديدة إلى خلق نوع من الإتارة، وحالة من

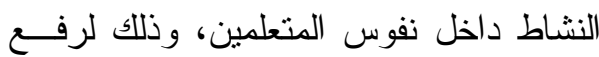

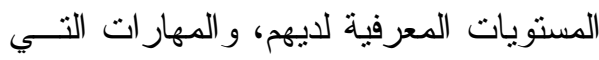
بحاجه إلى تعلمها، وتحفيز هم علـى إنجــاز

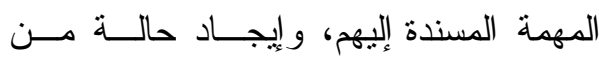

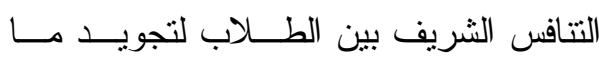
يتعلمونه بكل مرحلة تعليمية (زكريا جـابر

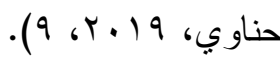
وقد أثبتت نتائج العديد من الدر اســات و البحوث العلمية التي أجريت حديثاً، فاعليــة محفزات الألعاب الرقمية في تتمية مخرجات

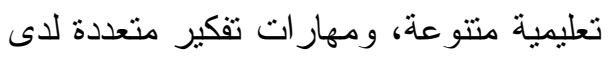

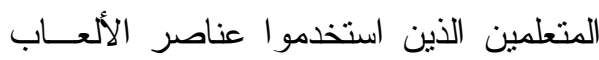
أثثاء عملية التعلم، فقد أثنارت در استة دونـــي التئي

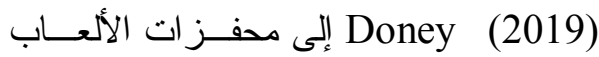
الرقمية تساعد على تتمية مهار ات التـصميم

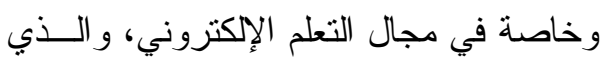
يتفق مع مهار ات تصميم مو اقع الويب، حيث

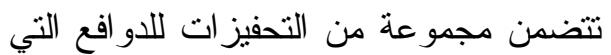

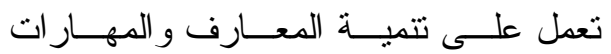
الخاصة بالتصميم. 
الرحيم (10 ب)، إلى أن الألعاب التعليميــة المقدمة لتلاميذ التعليم الأساسي تساعد بشكل التهل

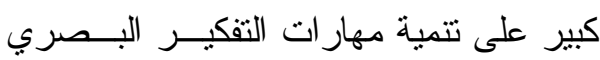

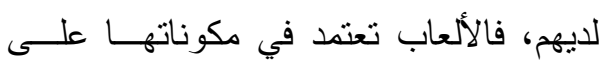
مجموعة من الصور و الرسومات و الأشــكال التي تتمي من مهار ات التفكير البصري لدى من لهن

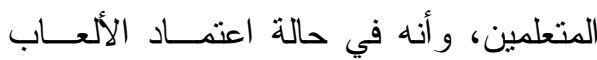
التعليمية على صـــور جذابــة وذات معنــى

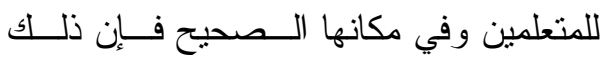

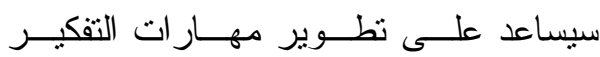

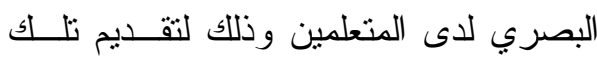
الصور في سياق غير تقليدي.

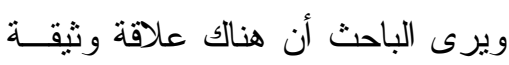

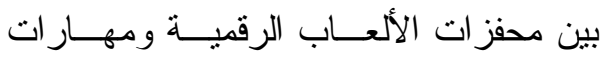

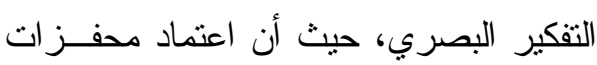
الألعاب على الصور و الرســوم و الاثــكال سواء في عرض المحتوى أو مسـن خــلال

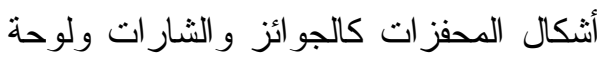
المتصدرين من المكونات الهامة و التي تظل

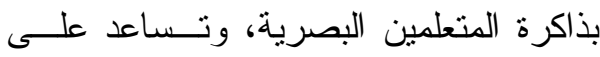

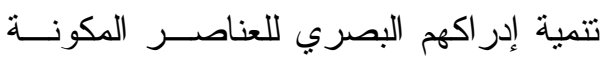
للعبة، كما تساعدهم على التمييز البـصري البهري بين المكونات المتتوعة لمو اقع الويب داخـلـل

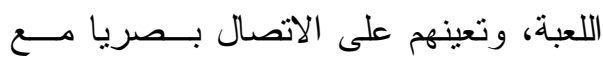
العناصر المكونة لمواقع الويب وكذا الاقران

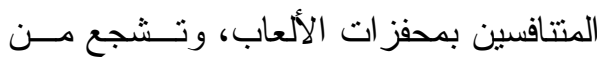

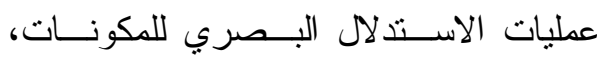

ارتباطية بين محفـز ات الألعــاب الرقميــة

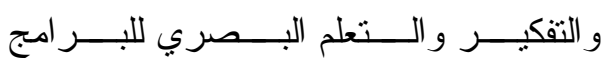

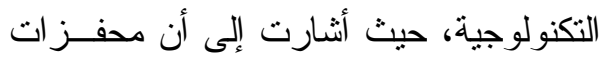
الألعاب الرقمية تدعم من التعلم البصري بما لتها

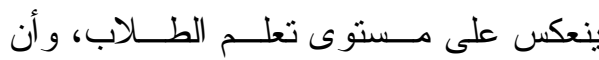
المعلومات البصرية التي يتعلمها الطلاب عند لهمل

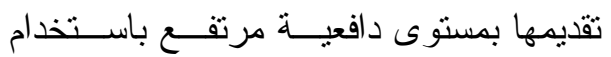

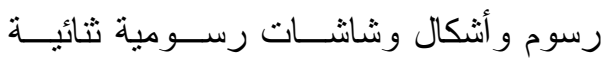

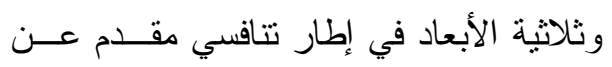

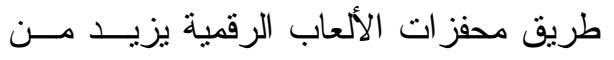

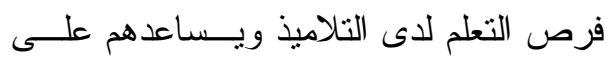

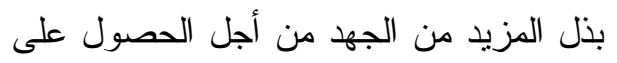
جو ائز وتحقيق مر اكز منقدمة بين الأقران.

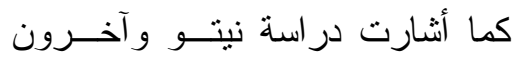
Neto, et al., (2014)

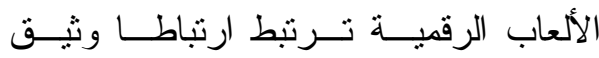

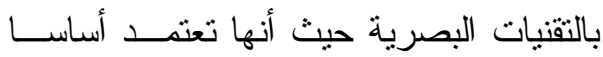
على الرسوم و الصور و العروض التي تثيــر

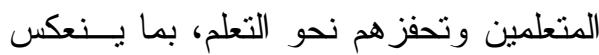
على مستوى التفكير البصري لدى المتعلمين،

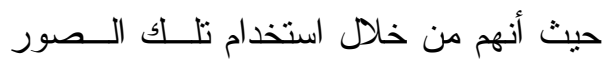
و الرسوم بمحفزات الألعاب الرقمية سيساعد على بقاء أثر التعلم لاى المتعلمين.

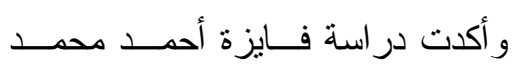

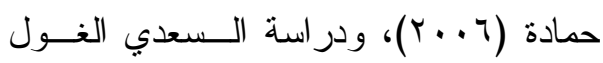

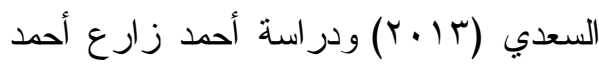

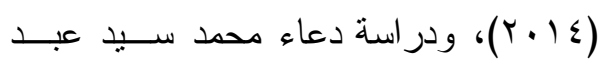




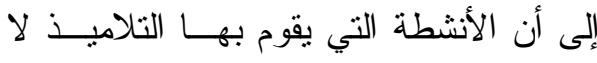

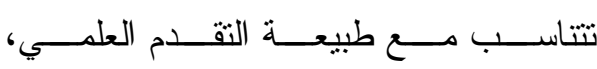

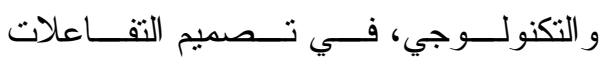

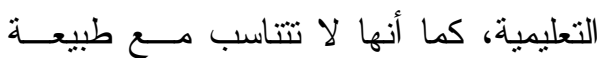
محتوى المادة التعليمية. وقد أكدت العديد من لهن لهن البحوث و الدراسات على وجود قصور فـي في وني

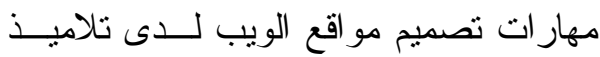

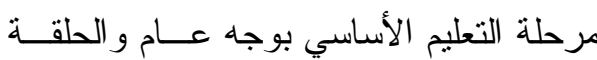
الإعدادية بوجه خاص، وهذا ما أشارت إليه

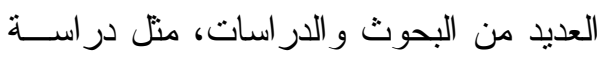

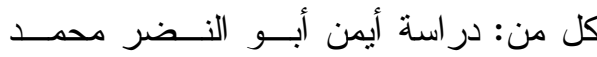

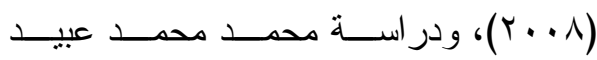

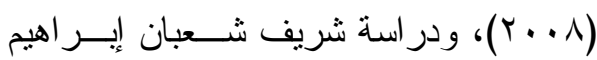

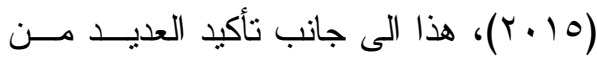
البحوث و الدراسات على وجود مشكلات في تعليم مهار ات تصميم مو اقع الويـبـ بــشكل عام، مثل دراسة كل مــن: حسـن عبــــاله

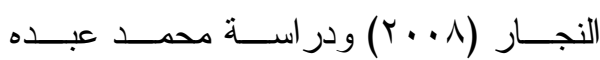

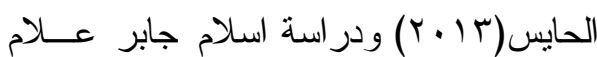

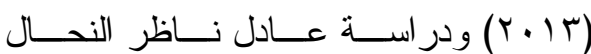
.$(r \cdot 17)$ كما أكــدت العديـــــــن البحــوث و الدر اسات على وجود مشكلات في مهار ات التفكير البصري لاى تلاميذ التعليم الأساسي تعيق من تعلمهم وتؤثر بشكل كبيــر علــى

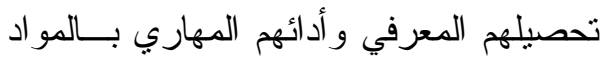
التعليمية المتتوعة، منل در اسة فايزة أحمــد
وتتمي من القدرة علــى التحليــل البـصري للعناصر المكونة للعبة المبنية على معسارف ومهار ات تصميم مو اقع الويب. ومما سبق بيضح لنا أهمية اســتخدام محفزات الألعاب الرقمية في تحويل طريقــــة

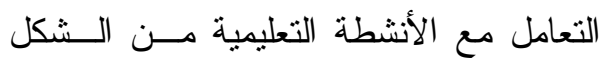
التقليدي الى شكل أكثر تفاعليــة وديناميكيــة ينمي معارف المتعلمين، ومهار اتهم بتصميم مو اقع الويب ويزيد من دافعيتهم نحو الــتعلم

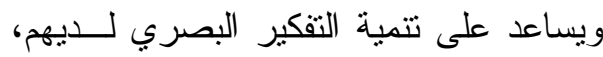

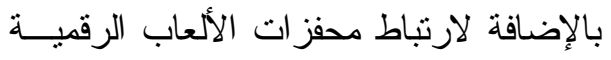

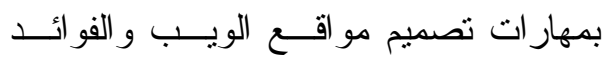
المتبادلة بين المكونين، و العلاقة القوية بــين

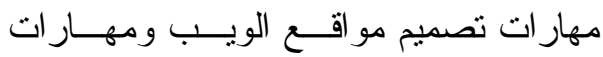

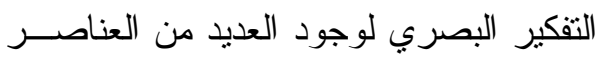
المشتر كة بينهما.

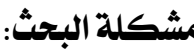

نبعت مشكلة البحث من خلال مناقشة الباحث مع عدد من معلمي مادة الكمبيــونز وتكنولوجيا المعلومات بالحلقـــة الإعداديــة،

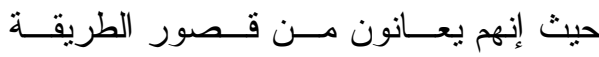
التقليدية في تدريس بعـض الموضـــوعات لاسيما تصميم مواقع الويب و المقررة علــى لــي تلاميذ الصف الثاني الاعدادي مما يؤدى الى لى لكي تدني مستوى التلاميذ نتيجة رصد صــعوبة لفية في تعلم و اتقان الجوانب المعرفية و الأدائيـــة

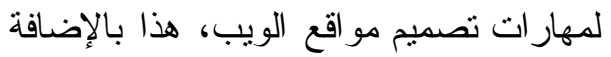


الدر اسة إلى حاجتهم الى التجديد في تعلم هذه

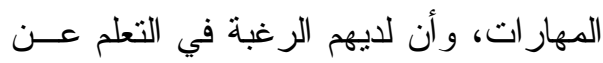

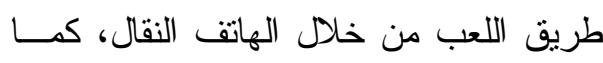

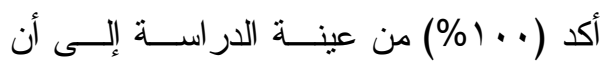

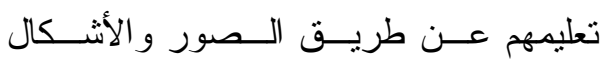

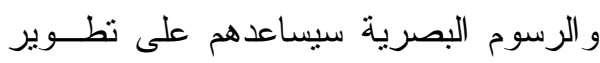
مستوى أدائهم بتصميم مو اقع الويب.

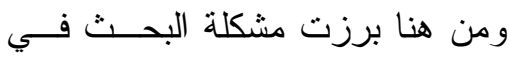

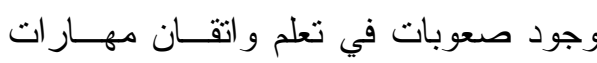
تصميم مو اقع الويــبـ ومهـــار ات التفكيــر

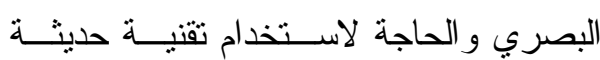

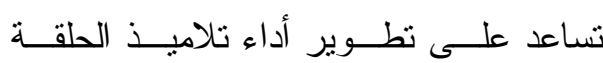
الإعدادية في تصميم مو اقع الويب. أسئلة البحث:

حاول البحث الإجابة عن الأسئلة التالية: ما أثر استخدام محفزات الألعاب الرقمية في لإسئه الإبه

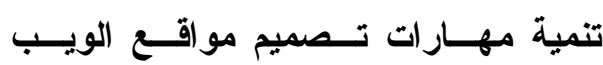

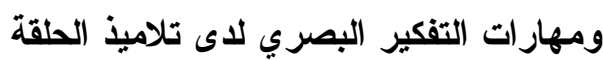

الإعدادية؟

ويتفرع مــن الــسؤال الرئيسـي الاســــلة الفرعية التالية:

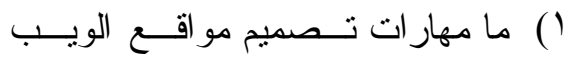

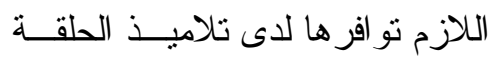

$$
\text { الإعدادية؟ }
$$

r) ما مهارات التفكير البصري الــلازم تو افرها لدى تلاميذ الحلقة الإعدادية؟
محمد حمادة (T · . T)، ودر اسة هنــد عبيــد

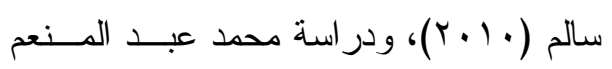

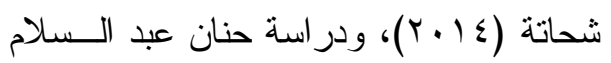

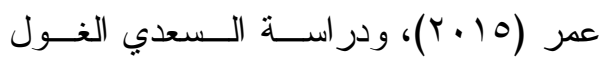

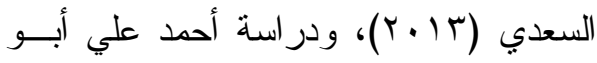

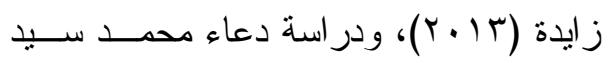

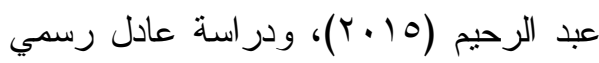

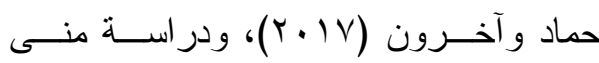

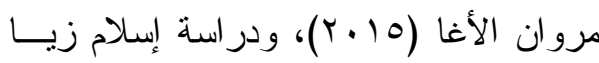

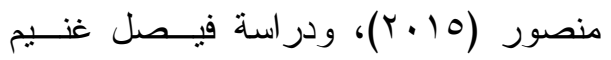

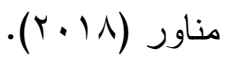
وللتأكد من مشكلة البحث قام الباحــث

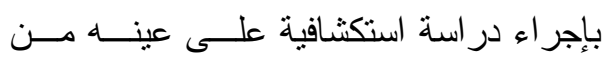
تلاميذ الصف الثاني من الحلقــــة الإعداديــــة (ذكور - اناث) خارج عينة البحث الأساسية مكونة من (Yo) تلميذ وتلميذة حول محتوى

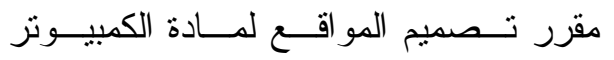

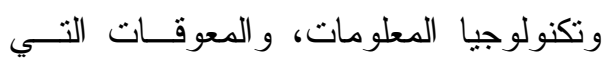

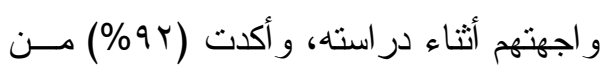
عينة الدراسة على وجود صعوبة في دراسة

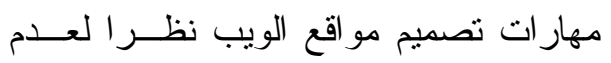

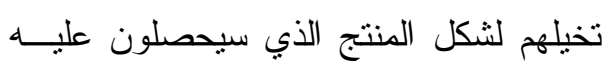
قبل البدء في التصميم، كمـــا أثنــار (197\%) من العينة الى الملل الذي ينتابهر عند تطبيق

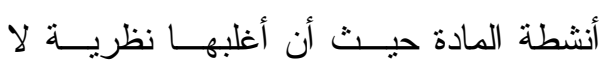
تتتاسب مع طبيعة محتوى مهار ات تــصميم

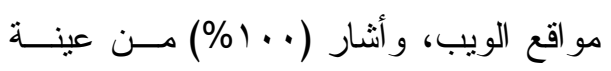




$$
\begin{aligned}
& \text { r. تحديد مهار ات التفكير البصري اللازم } \\
& \text { ץ) ما التصور المقتر حلمحفزات الألعاب } \\
& \text { تو افر ها لدى تلاميذ الحلقة الإعدادية. }
\end{aligned}
$$

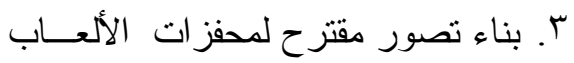

$$
\begin{aligned}
& \text { الرقمية في تتميــة مهــار ات تـصميم }
\end{aligned}
$$

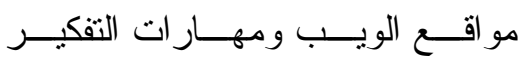

$$
\begin{aligned}
& \text { البصري لدى تلاميذ الحلقة الإعدادية. }
\end{aligned}
$$

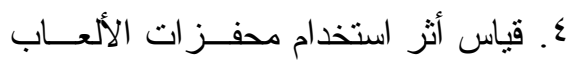

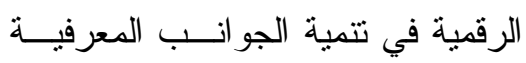

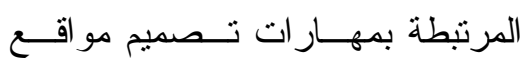

$$
\begin{aligned}
& \text { الويب لدى تلاميذ الحلقة الإعدادية. }
\end{aligned}
$$

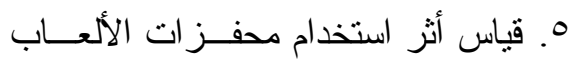

$$
\begin{aligned}
& \text { الرقمية في تتمية الجوانـبـ الأدائيــة }
\end{aligned}
$$

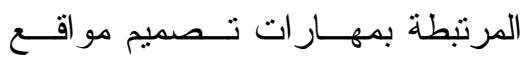

$$
\begin{aligned}
& \text { الويب لدى تلاميذ الحلقة الإعدادية. }
\end{aligned}
$$

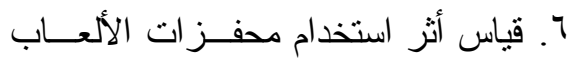

$$
\begin{aligned}
& \text { الرقمية على تتمية مهـــار ات التفكيــر } \\
& \text { البصري لدى تلاميذ الحلقة الإعدادية. }
\end{aligned}
$$

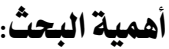

$$
\begin{aligned}
& \text { قد يفيد هذا البحث في: } \\
& \text { 1. الوقوف على مهارة تــصميم مواقــع }
\end{aligned}
$$

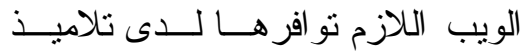

$$
\begin{aligned}
& \text { الحلقة الإعدادية. } \\
& \text { r. العمل علي تحسين وتطـــوير قــدرات الات } \\
& \text { التلاميذ تكنولوجياً بشكل مستمر . }
\end{aligned}
$$

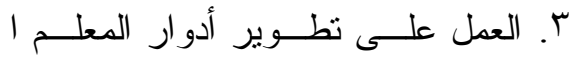

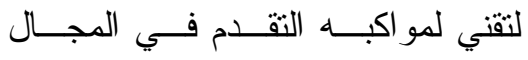

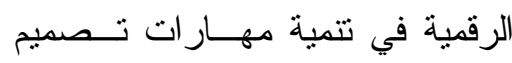

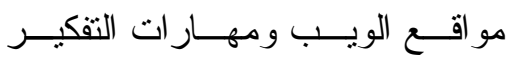

$$
\begin{aligned}
& \text { البصري لدى تلاميذ الحلقة الإعدادية؟ }
\end{aligned}
$$

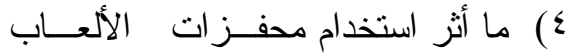

$$
\begin{aligned}
& \text { الرقمية في تتمية الجوانب المعرفيــة }
\end{aligned}
$$

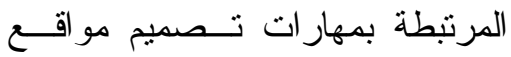

$$
\begin{aligned}
& \text { الويب لاى تلاميذ الحلقة الإعدادية؟ }
\end{aligned}
$$

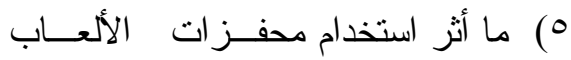

$$
\begin{aligned}
& \text { الرقمية في تتمية الجو انــب الأدائيــة }
\end{aligned}
$$

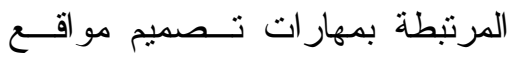

$$
\begin{aligned}
& \text { الويب لاى تلاميذ الحلقة الإعدادية؟ }
\end{aligned}
$$

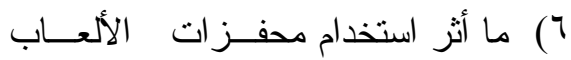

$$
\begin{aligned}
& \text { الرقمية في تتمية مهــار ات التفكيـر } \\
& \text { البصري لدى تلاميذ الحلقة الإعدادية؟ }
\end{aligned}
$$

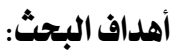

$$
\begin{aligned}
& \text { هدف البحث الحالي إلى علاج أوجــه }
\end{aligned}
$$

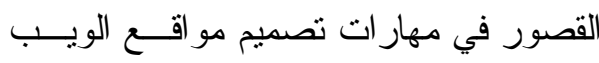

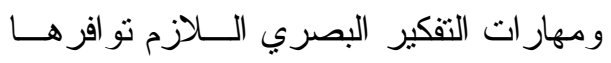

$$
\begin{aligned}
& \text { لدى تلاميذ الحلقة الإعدادية؛ و الذي قد يرجع }
\end{aligned}
$$

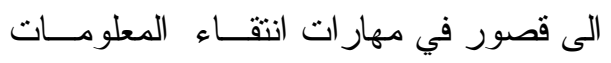

$$
\begin{aligned}
& \text { التي نتاسبهم وسط الكم الهائل من المعلومات }
\end{aligned}
$$

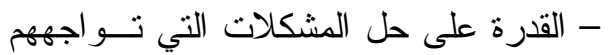

$$
\begin{aligned}
& \text { بالمتغير ات الأساسية المختلفة لبنــاء أحكــام } \\
& \text { موضوعية، وذللك من خلال: }
\end{aligned}
$$

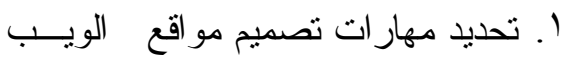

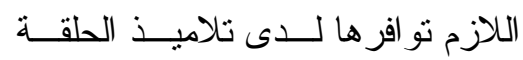

$$
\begin{aligned}
& \text { الإعدادية. }
\end{aligned}
$$




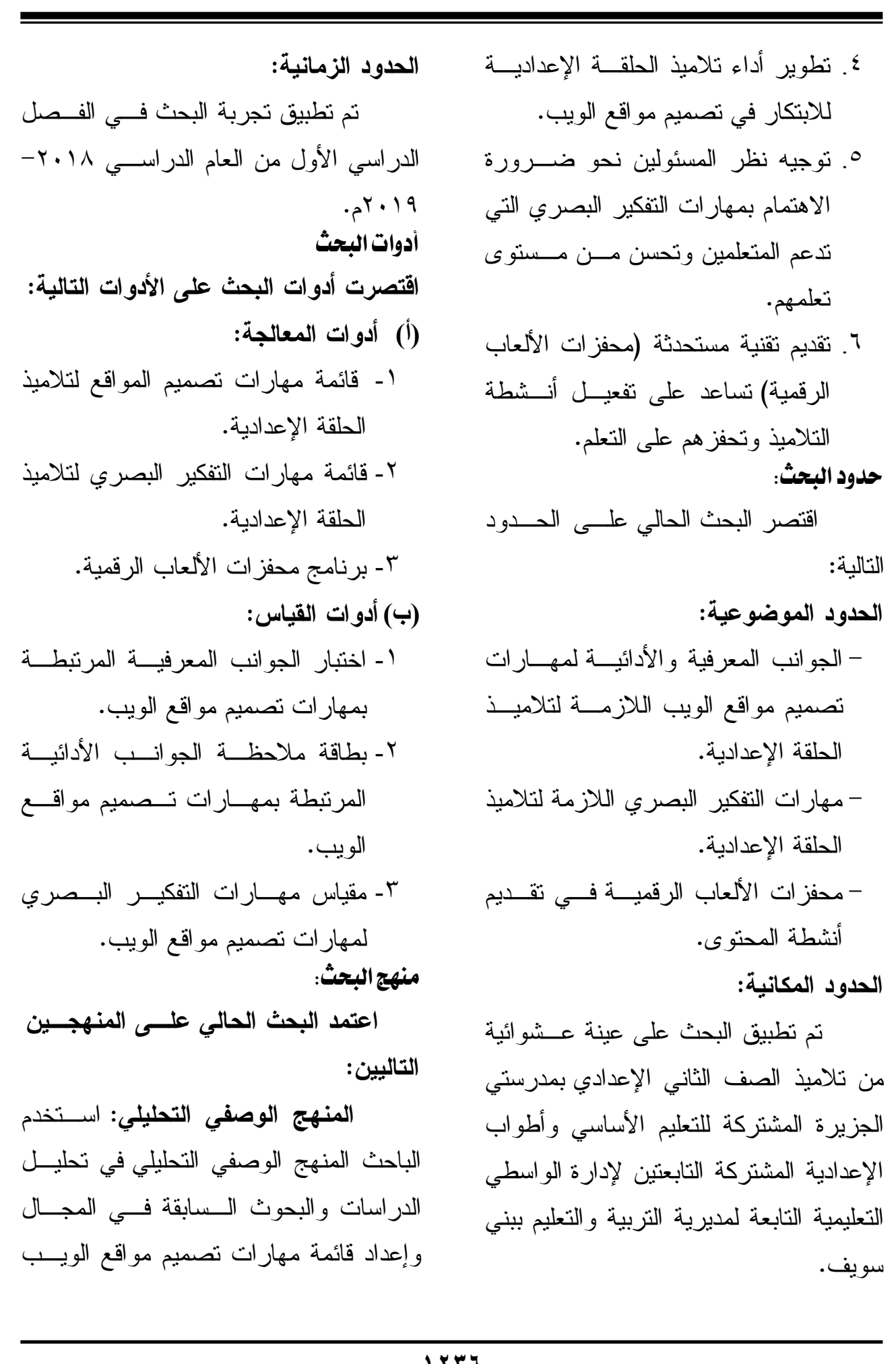




$$
\begin{aligned}
& \text { بمحتــوى كتــاب الكمبيــوتز وتكنولوجيــا التابعة لمديرية التزبية و التعليم ببني سويف، }
\end{aligned}
$$

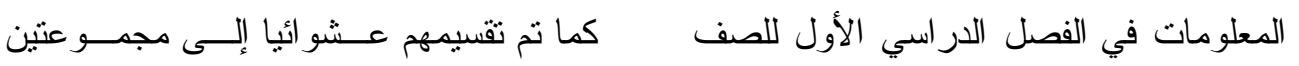

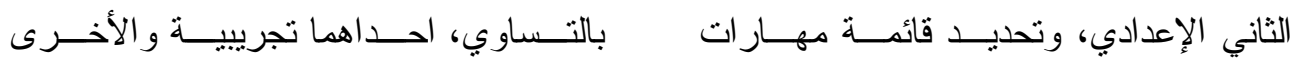

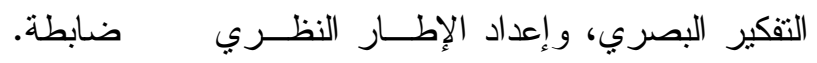

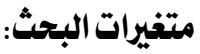

$$
\begin{aligned}
& \text { - المتغير المستقل: } \\
& \text { محفز ات الألعاب الرقمية. }
\end{aligned}
$$

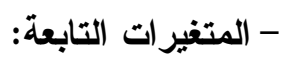

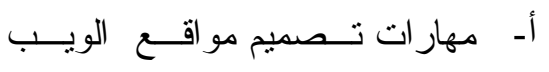

$$
\begin{aligned}
& \text { (الجوانب المعرفية و الأدائية). } \\
& \text { ب- مهار ات التفكير البصري. } \\
& \text { التصميم التجريبي للبحث: }
\end{aligned}
$$

\begin{tabular}{|c|c|c|c|}
\hline التطبيق البعدي & المعالجة & التطبيق القبلي & المجموعات \\
\hline 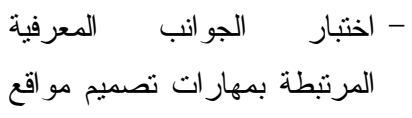 & محفز ات الألعاب & - المرتبطة الجوانب المعرفية & التجريبية \\
\hline - الوباقة ملاحظة الجوانب الأدائية & الطريقة السائدة & - مواقة ملاقعة الويب الجو انب الأدائية & الضابطة \\
\hline
\end{tabular}

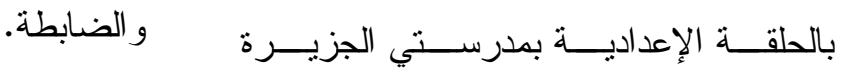

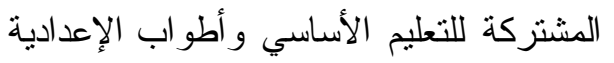

$$
\begin{aligned}
& \text { الششتركة التابعتين بإدارة الو اسطي التعليمية }
\end{aligned}
$$

جدول (1) التصميم التجريبي للبحث 


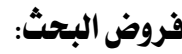

درست باستخدام محفــزات الألعـــاب الرقمية بالتطبيقين القبلــي و البعـدي لبطاقة ملاحظـــة الجو انــب الأدائيــة

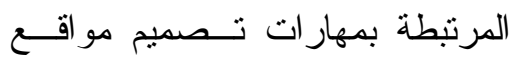
الويب لصالح التطبيق البعدي. 0- يوجد فرق ذو دلالة إحـصائية عنـــ

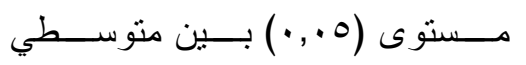

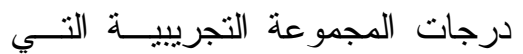
درست باستخدام محفــز ات الألعـاب الرقمية، و المجموعة الضابطة التـي بالي درست بالطريقة التقليدية في بطاقــة

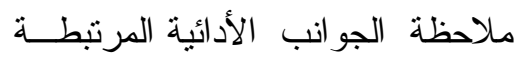
بمهار ات تصميم مو اقع الويب لصالح المجمو عة التجريبية. 7- ـيوجد أثز إيجابي لاستخدام محفـزات

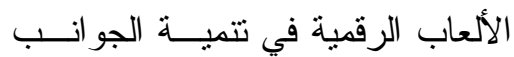
الأدائية المرتبطة بمهــار ات تـصميم مو اقع الويب لــدى تلاميــــ الحلقــــة الإعدادية. V- يوجد فروق ذات دلالة إحصائية عند

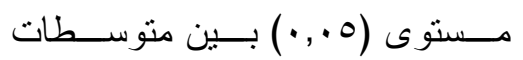
درجات المجموعة التجريبيــة التـي مئوسي

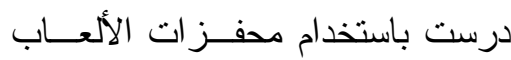

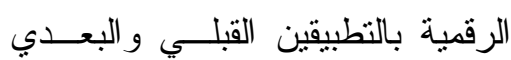

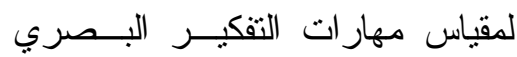
لصالح النطبيق البعدي.
1 - يوجد فرق ذو دلالة إحــصائية عنـــ

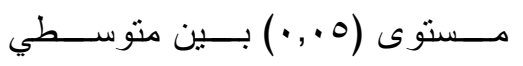

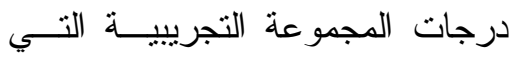
درست باستخدام محفـز ات الألعــاب الرقمية بالتطبيقين القبلـي و البعـدي

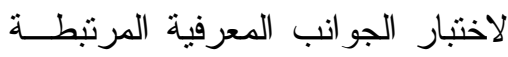
بمهار ات تصميم مواقع الويب لصالح التطبيق البعدي. r- يوجد فرق ذو دلالة إحــصائية عنــــ

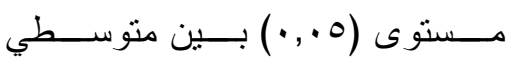

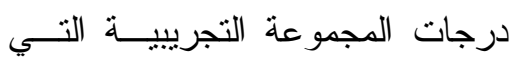
درست باستخدام محفــز ات الألعــاب الرقمية و المجموعة الــضابطة التـي بــي درست بالطريقة التقليدية في اختبــار الجوانب المعرفية المرتبطة بمهارات

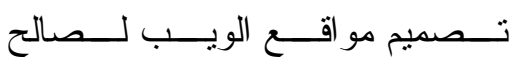
المجمو عة التجرييية. r- يوجد أثز إيجابي لاستخدام محفـزات

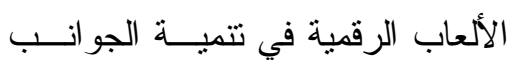
المعرفية المرتبطة بمهار ات تـصميم مو اقع الويب لـــى تلاميــــ الحلقــــة الإعدادية.

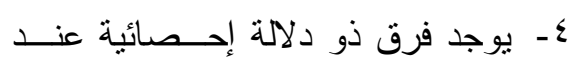

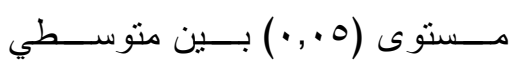
درجات المجموعة التجريبيــة التـي لئي 
ويعرف الباحث محفـز ات الألعــاب

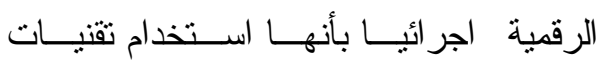

وعناصر الألعاب و ادماجها داخل الأنـشطة بـانه

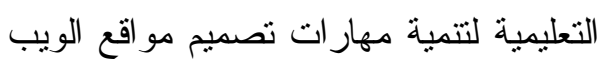

ومهار ات التفكير البصري لدى تلاميذ الحلقة

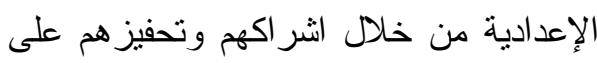

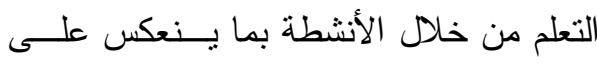

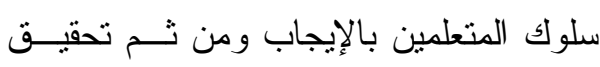

أهدافهر.

مهار ات تصميم مواقع الويب:

يعرفها الباحث إجرائيا بأنها القــدرات

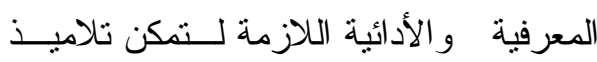

الصف الثاني الإعدادي من تــصميم مو اقــع

الويب موظفين المهار ات الأساسية لتـصميم

المواقع وذلك باستخدام لغة HTML، ويـتنم

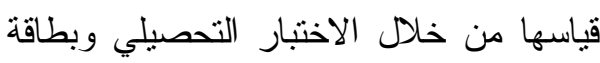

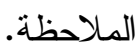

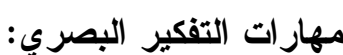

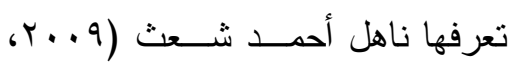

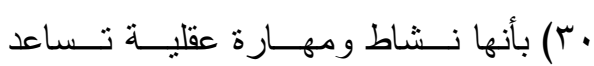

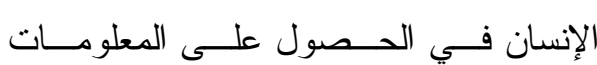

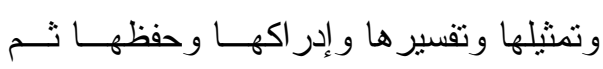

التعبير عنها وعن أفكاره الخاصـــة بــصريا

ولفظيا، وذلك من أجل تحقيق التواصل مـــع

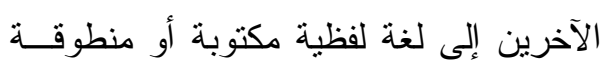

$$
\text { و استخلاص المعلومات منه. }
$$

1- يوجد فروق ذات دلالة إحصائية عند

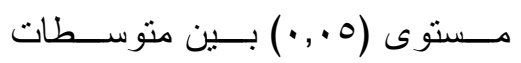

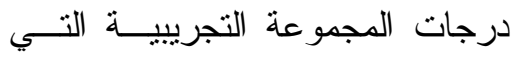

درست باستخدام محفــز ات الألعــاب

الرقمية، و المجموعة الضابطة التـي بلي

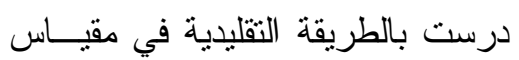

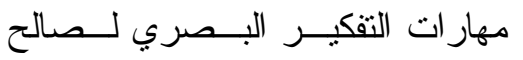

المجمو عة التجريبية.

9 - يوجد أنز إيجابي لاستخدام محفـزات

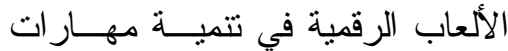

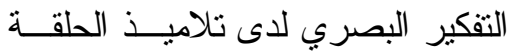

$$
\text { الإعدادية. }
$$

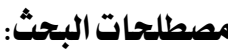

اثتنمل البحــث علــى المــصطلحات

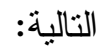

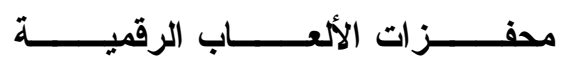

:(Gamification)

تعرف بأنها استخدام عناصر تصميم

الألعـــاب فــي ســـاقات غيـــر اللعـــب.

(Deterding, et al, 2011, 10)

ويعرفها ميلو وآخـرون ( Melo, et

بأنها إدمــاج عـدد مـنـ (al., 2014, 564

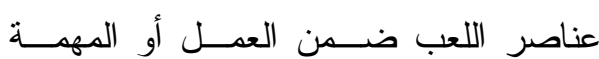

المطلوبة، ومن هذه العناصر : قصنة اللعبـــة،

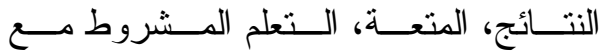

التحديات، و البر اعة، ومؤشر ات التقدم (نقاط

- شار ات.....)، و التو اصل، وتحكم اللاعب. 
محفز ات الألعاب الرقمية، و أدو ات وتطبيقات محفز ات الألعاب الرقمية في التعليم:

مفهوم محفزات الألعاب الرقمية:

يثير كاب (Kapp,2012) إلـى أن

مفهوم محفز ات الألعـــاب الرقمبــة ارتــبط

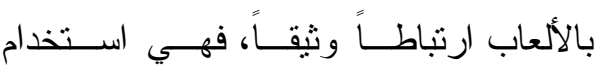
الميكانيكا القائمة على اللعب، و التفكير فــي إثر الك اللاعبين، وتحفيزهم على المــشاركة الفعالة، وتعزيز الــتعلم لحــل المــشكلات، و هناك نوعان من محفز ات الألعاب الرقميـــة كما أوضحهم انــدرس Enders, 2013

$:(1)$

• محفز ات الألعــاب الرقميــة الهيكليــة Structural Gamification تطبيق عناصر اللعبة من خلال المحتوى بدون أي تغيير على المحتوى، و التركيز الأساسي لهذا النوع هو تحفيز المتعلمين على الاندماج في المحتوى و إثـــر اكهم في عملية التعلم من خلال المكافآت.ومن العناصر الأكثر شيوعاً في هذا النــوع:

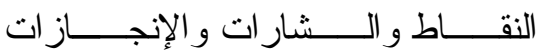
و المستويات.

• محفز ات الألعــاب الرقميــة Content Gamification اللعبة و التفكير لتغيير المحتوى، وجعلـــه يشبه اللعبة.

$$
\begin{aligned}
& \text { يعرفها الباحث اجرائيا بانهــا قــدرة } \\
& \text { عقلية مرتبطة بحاسة البصر لــدى تلاميــذ } \\
& \text { الصف الثاني الإعـــدادي بمـــادة الكمبيـــــر }
\end{aligned}
$$
ولفظيا.

الإطار النظري والدراسات السابقة:

يتتـــاول الإطــــار النظـــري للبحــــث

محفزات الألعاب الرقمية، ومهار ات تصميم مواقع الويب، ومهار ات التفكير البــصري، وذلك على النحو التالي: المحور الأول- محفزات الألعاب الرقمية :

تتاول هذا المحور مفهـــوم محفــز ات الألعاب الرقمية، ومكونات محفز ات الألعاب الرقمية، وعناصر وتقنيات محفز ات الألعاب الرقمية، و إيجابيات توظيف محفز ات الألعاب الرقمية في العملية التعليمية، وفو ائد محفز ات الألعاب الرقمية في العملية التعليمية، و آليات نجاح توظيف محفز ات الألعاب الرقمية فــي التعليم، والنظريات التزبوية التي تبنى عليها 
و النجوم من الأنماط التي لها تأثنير تحفيـزي على الطلبة (Carey,2007). ومن هنا يمكـن توظيــف محفـز ات الألعاب الرقمية في تتمية معارف ومهــار ات

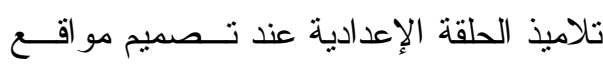
الويب، فهي تحفز من تتافسهم فيمـــا بيــنهم

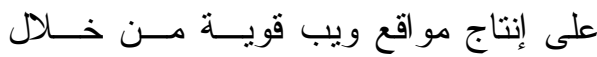

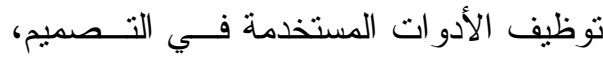
وتشجعهم على توليد أفكار ا غير تقليدية فـي تصميم مو اقع الويب بحيث تصمم فـــي أقــلـل

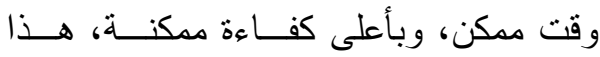
بالإضـافة على اعتمــاد محفـز ات الألعــاب الرقمية على المعلومات المصورة و الأشكال و التي من شــأنها أن تــــاعد علـــى تتميـــة مهار ات التفكير البصري لاى التلاميذ و التي لا غنى عنها في تعلم مهار ات برمجة مواقع

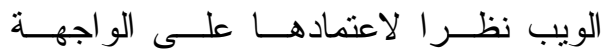

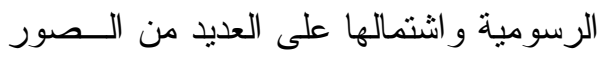

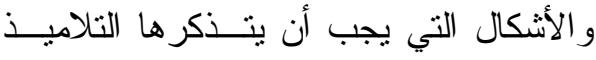
ويوظفونها عند انتاجهم لمو اقع الويب. وبذلك تتضح أهمية محفزات الألعاب

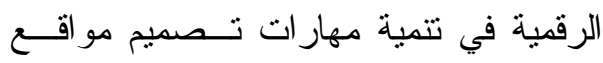
الويب ومهار ات التفكير البصرى، وذللك من خلال احر از النقاط والانتقال من مستوى الى ولى مستوى أعلى ونظام المكافآت؛ حيث يستخدم نمط احر از النقاط بمنح المتعلم نقاط كلما قام

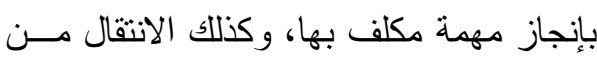

ولذا سعى الباحث نحو الــدمج بـين

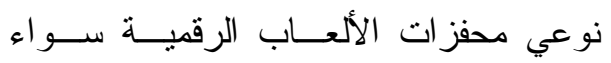

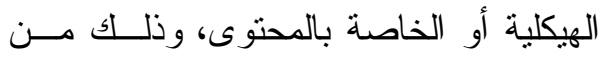
خلال إثثر الك المتعلمين فــي عمليـــة الــتعلم باستخدام الزمن كتحدي وإضافة المكافــآت،

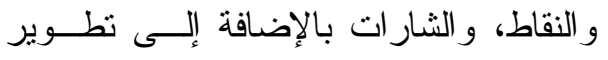

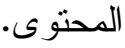

وتقوم محفز ات الألعاب الرقمية علــى

تحقيق الأهداف فــصبرة المــدى وطويلـــة المدى، و التي تعطي شـــعور ا سلــسًا لتقـــدم اللاعبين (المتعلمـين) مــن خــلال تـــوفير المكافآت المتكررة؛ و التــي تكــــن بمثابــة المحفز ات الخارجية، وهي تعتمد أيضًا على لى نظريات علم النفس المختلفة، باستخدام نماذج

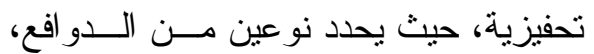
خارجي وداخلي، ويمكن أن تستخدم لإشر الك

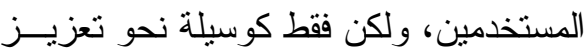
الدو افع الداخلية الأصيلة في النـشـاط نفـسه

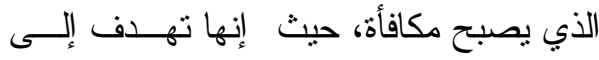
Domínguez, et ) تعزيز سلوكيات معينة

(al, 2013 و هناك أنماط تحفيز متعددة تقدم مـنـ خلال محفز ات الألعاب الرقمية، والتي تعمل على زيادة دافعية المتعلمـين نحسـو الــتعلم (O'Donovan, Gain \& Marais, (2012، وتعد اثـــرطة الثقــدم و الــشارات 
قسم كل من هونيك وليبلانس وزوبك

(Hunicke, Leblanc\& Zubek, 2004) مكونات محفزات الألعاب الرقمية إلى ثلاث

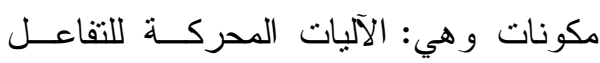

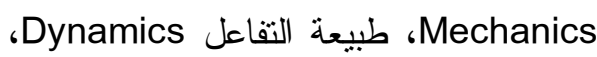
جماليات اللعبة Aesthetics كــــا بالـشكل طئس

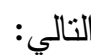

مستوى الى مستوى أعلى، وذللك بــالتحرك

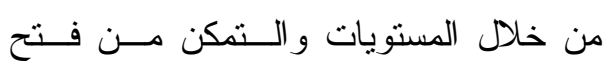
محتوى جديد أو تحديا جديدا، كما يعتبر نظام المكافآت من الأنماط الأكثر إثــارة للمــتعلم و التي يسعى المتعلم للحصول عليهــا، ويــتم

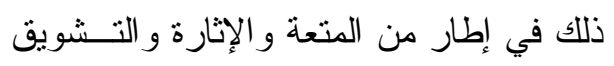
وبشكل غير تقليدي مما يدفع المتعلم لتأديـــة

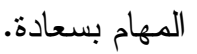
مكونات محفزات الألعاب الرقمية:

\begin{tabular}{|l|}
\hline المتعة \\
Fun \\
\hline
\end{tabular}

\begin{tabular}{|c|}
\hline النظام \\
System \\
\hline
\end{tabular}

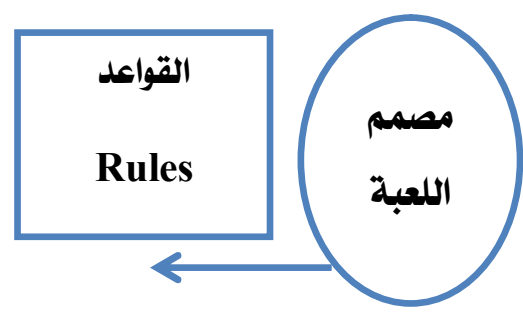

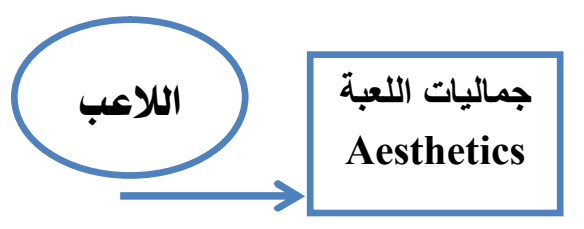

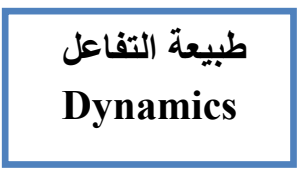

$$
\begin{gathered}
\text { الآليات المحركة } \\
\text { Mechanics }
\end{gathered}
$$

شكل (1) مكونات محفزات الألعاب الرقمية (Hunicke, Leblanc\& Zubek, 2004)

$$
\begin{aligned}
& \text { داخل اللعبة التي لا تتغير من لاعب لآخــر، }
\end{aligned}
$$

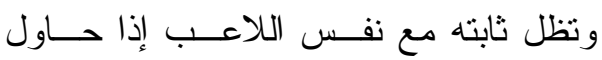

$$
\begin{aligned}
& \text { الدخول مرة أخرى للعبة. }
\end{aligned}
$$

\section{:Mechanics}

وقد أنثار ميلو وآخرون ( Melo, et

(Hunicke, Leblanc\& Zubek, 2004)

(al., 2014, 552-553

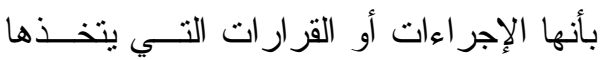

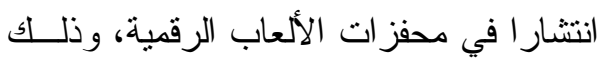

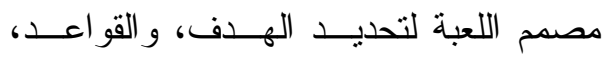

$$
\text { على النحو التالي: - مئي }
$$


ثانياً: طبيعة التفاعل Dynamics:

Werbach \& ) يرى ويربالك و هانتر

(Hunter, 2012 عن قو اعد وقوانين اللعبة فهي نتكل الهيكل الضمني و العوامل المفاهيمية التـي تـشكل إطار اللعبة، وتوضح طبيعة العلاقــة بــين

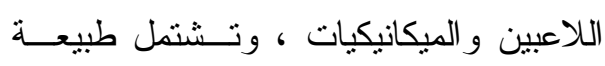
التقاعل على:

• القيود Constraints: الحدود الملزمة.

• المشاعر Emotions: حب الاستطلاع - التتافس - الاحباط - السعادة.

• السرد Narrative: وهو الهيكل الـــي

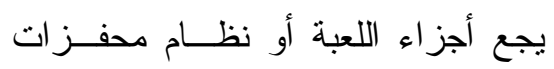

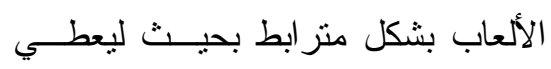
الشعور بأنه كل.

• التقدم Progression : نمــو وتطـــور

$$
\text { اللاعب. }
$$

• العلاقات Relationships: التفــاعلات الاجتماعية و الصداقة و التعارف.

ثالثاً: جماليات اللعبة Aesthetics:

ويقصد بها الاســتجابات المرغوبـــة ومظهر اللعبة، ويرى روبـسون وآخـرون (Robson et al, 2015) المرغوبة تتمنل بالثعور الذي ينت بناؤه داخل

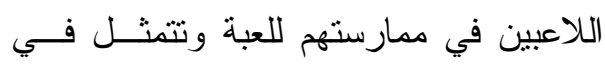

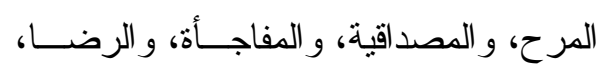

• النقــاط Points: تــستخدم لمكافــأة

ولاستثارة سلوكيات محددة ونوضـح مؤشر التقدم.

• المستويات Levels: هي مؤشــرات

لوصول المسستخدم لمسستوى مــن هرون

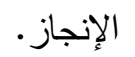

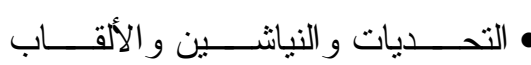

Challenges, Trophies,

Badges

بالمهام التـي ســـيتم إنجاز هـــا، أمســا

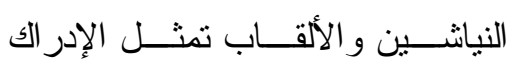

المرئي للوصول لمستوى معين.

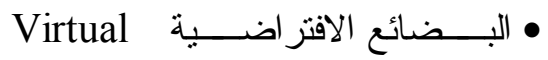

Goods

فعالية من خلال إيجاد مكان لــصرف تصن

$$
\text { النقاط و استبد الها. }
$$

• قوائم الشرف Leader Boards: هي

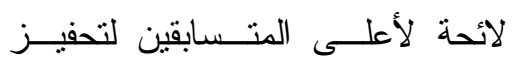

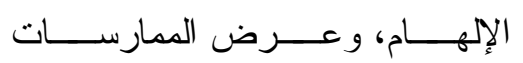

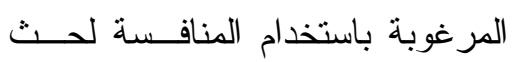
السلوك الجيد.

• (Paharia,2013) وأضاف باهاريــا

آلبات التغذية الر اجعـة Feedback:

و هي طريقة تقديم التغذيــة الراجعــة

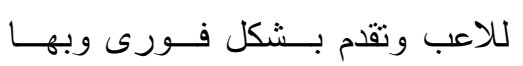

دافعية. 


$$
\begin{aligned}
& \text { استخدام هذه المنهجية في مرحلة بناء }
\end{aligned}
$$

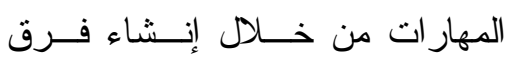

$$
\begin{aligned}
& \text { وتحديد هوية أو سمه لكل فريق. } \\
& \text { ع - حرية بذل الجهد: تساعد في تحسسين }
\end{aligned}
$$

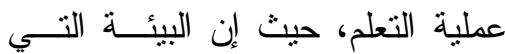

$$
\begin{aligned}
& \text { تعتمد على تطبيقات محفزات الألعاب } \\
& \text { الرقمية يتم فيها التتاوب بين الفتــرات } \\
& \text { التي تتطلب تركيز شــديد، وفتــرات } \\
& \text { الر احة؛ ليستعبد الطـــلاب تركيــزهم } \\
& \text { بصورة طبيعية. }
\end{aligned}
$$

فو ائد محفزات الألعاب الرقمية في العمليــة التعليمية:

أكدت العديد مــن الدراســات علـى في

مميزات محفز ات الألعاب الرقمية في العملية

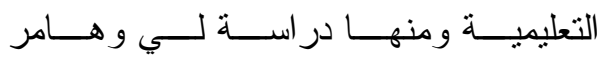

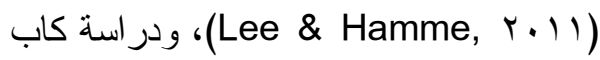

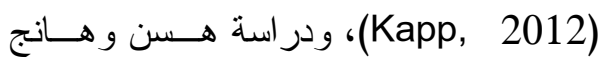

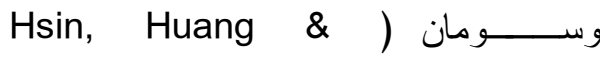

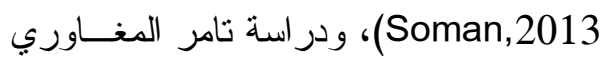

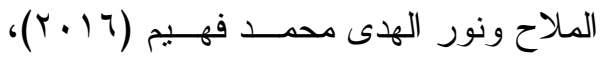

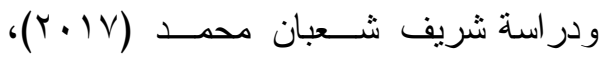
ودر اسة نبيل جاد عزمي و اخرون (Y (Y) (Y)،

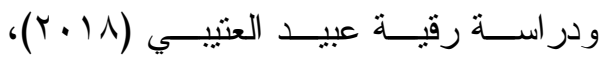
ودر اسة زكريا جابر حناوي وماريان مــيلاد

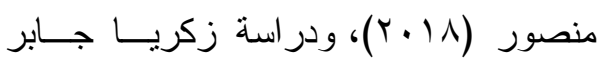

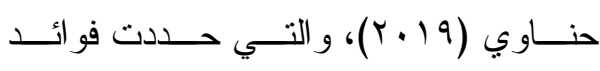

و السعادة، و الغيرة، و الفخر • و أكد كيم ولـــي (Kim \& Lee ,2013,185) اللعبة يتمنل في الألوان و التتوع و الأصــالة و البهجة وفنون عرض مر احل اللعبة. إيجابيات توظيف محفزات الألعاب الرقميــة في العملية التعليمية: تتمنل إيجابيــات محفــز ات الألعــاب

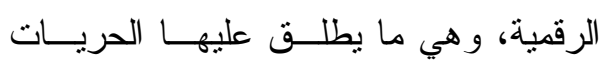

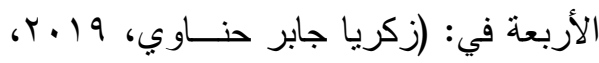
(Oxford Analytica, 2019) (70 1 - ـ حرية الفثل: حيث تتضمن المفــاهيم الرئيسية لمحفزات الألعاب الرقميــة

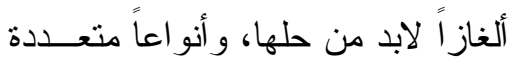
للشخصيات يتم تحديــدها بالاعتمــاد على فرضية تكرار فــثل اللاعبـين لــين أثناء تعلمهم كيفية اللعب. r- حرية التجربة: عندما يمنلك الطلاب

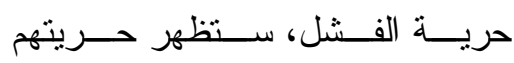
بالتجربة، وتقتح التجربة الباب أمسام سبل أكثر للتعلم الذاتي، وبالتالي تعزز ونه من حجم وجوده التعليم، وتعزيز حجم المعرفة لدى المتعلمين. r- حرية الحـصول علـــى شخــصيات مختلفة: تعد الأكثر أهمية في مرحلة

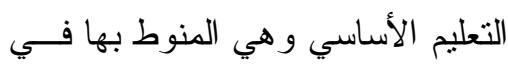

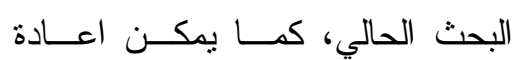




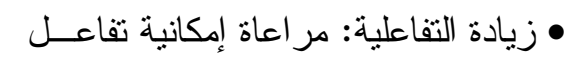

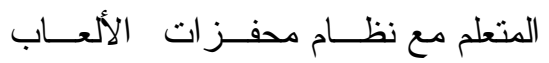

الرقمية بحيث تر اعي الفروق الفرديـــة بين كآفة المتعلمين.

• التحفيز المستمر على التعلم.

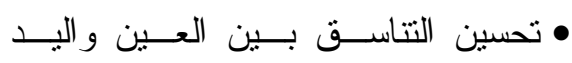

و المهار ات الحركية الدقيقة.

• زيادة الفهم و الاستيعاب و التشجيع علــى

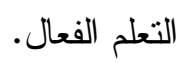

• زيادة الكفاءة الذاتية للتناميذ.

• منح فرصة النعلم باستخدام الثخصيات

$$
\text { الافتر اضية. }
$$

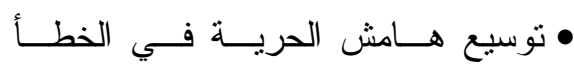
و المحاولة مرة أخرى دون أي انعكاسات

سلبية.

• • توفر خبر ات تعليمية أفضل.

• تحسن الاكتساب و الاحتفاظ بالمعرفة.

• زيادة مشاركة المتعلم وفاعليته.

ويرى الباحث أن محفزات الألعـاب

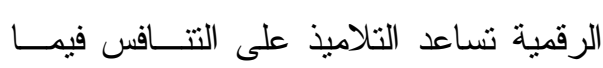

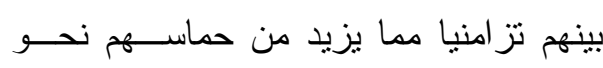

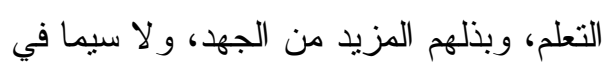

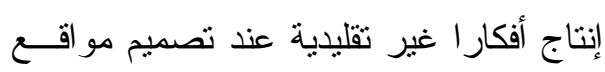

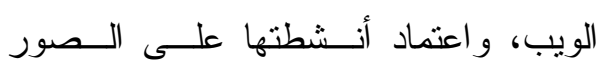

و الرسوم والأشكال يساعد على نتمية التفكير
محفزات الألعاب الرقمية في العملية التعليمية في النقاط النالية:

• تعزز محفزات الألعاب الرقمية الـتعلم من خلال المحاولة و الخطأ.

• نوفر محفزات الألعاب الرقميـــة بيئــة تعليمية مرنة لتسهيل التعلم. • تساعد المتعلمين على الثقة بأنفسهم.

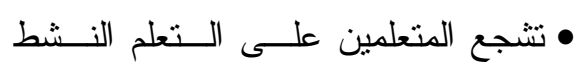
و التعلم من خلال الممارسة.

• تحفز التلاميذ على الاندماج في الفصول

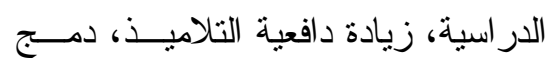
التعلم بالمتعة و الترفيه. • تساعد التلاميذ علــى الــتعلم بطريقـــة مشوقة ومختلفة عن النمط التقليدي. • تزيد التتافس الايجابي بين التلاميذ بشكل

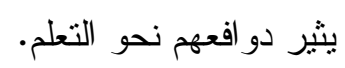
• نقدم تغذية راجعة فورية؛ حيث يعـرف

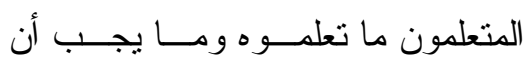
يتعلموه، ويحصل المتعلمون على تأكيد

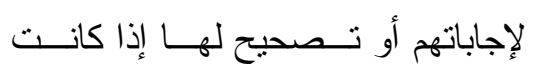
خاطئة. • تعزيز المشاركة: ويتم ذلك من خــلاد

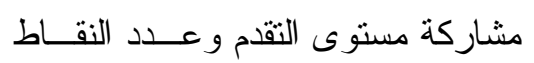
و الأهداف التي يحققها المتعلمون أنتــاء

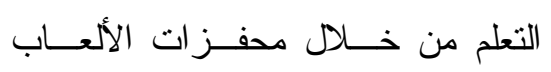

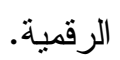


r. تحديد مسار وقو اعد التعلم: وفيها ينم

ربط المكافآت بأهداف التعلم، مثل ربط

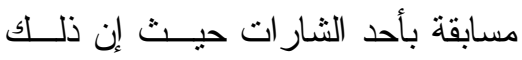

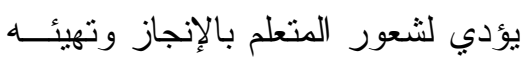
للانتقال إلى التحدي التالي.

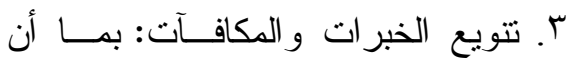
هناك مجموعة من المتعلمين مشتركين

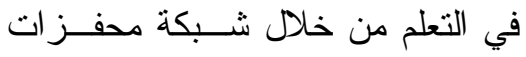

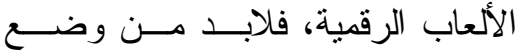

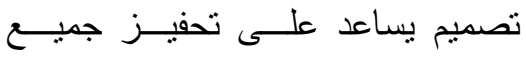
المتعلمين بنسب متفاوتة وفقا لمستوى

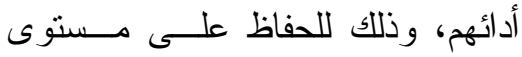
التحفيز، مثل توفير مجموعة متتوعــة

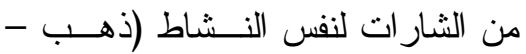

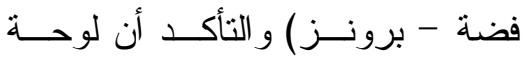
المتصدرين تعكس ذلك.

ع. الاهتمام بسيناريو التعلم: حيث تتطلب محفز ات الألعــاب الرقميــة مجهـــودا

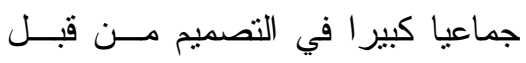
المبرمجين ومصممي المحفزات، وبذل

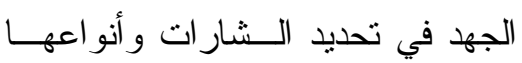

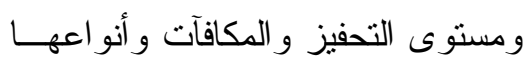
و آليات تطبيقها، ويتم الاعتماد على هذا السيناريو في مرحلة الإنتاج.

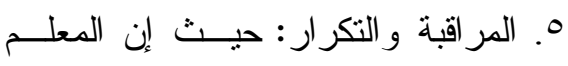

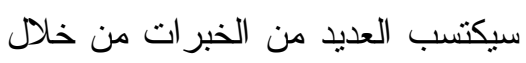

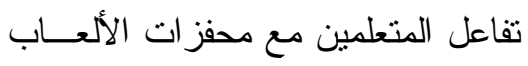

البصري لاى التلاميذ و التي ترنبط ارتباطــا

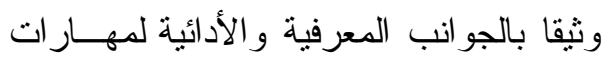
تصميم مو اقع الويب.

ولكن هناك بعض أوجــه القــصور و الجو انب السلبية لاستخدام محفزات الألعاب

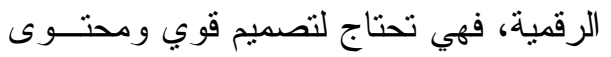
غني بالوسائط و المثير ات البــصرية، وفــي

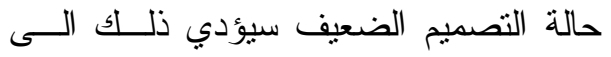
تشتت انتباه المتعلمين و إثارة جو من التـــونز

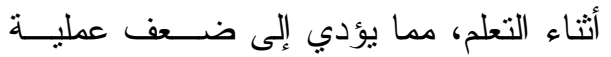
التعلم بدلا من تعزيز ها. آليات نجــاح توظيــف محفـز ات الألعــاب الرقمية في التعليم: لتوظيف محفزات الألعاب الرقميــة بــشكل ناجع لابد من مراعاة ما يلي: (Joomun ) 2018) 1. فهم طبيعة المتعلمين: حيث إنه لابد من تعرف خصائص المتعلمين إلى جانــب

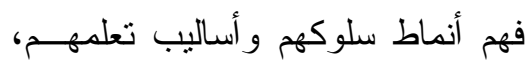

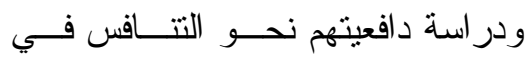
اللعب و التعلم ومدى تــأثنير تحفيـز هم

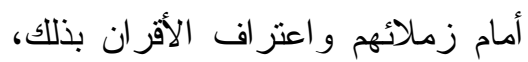
ومن أفضل الطرق لتحقيق ذلك: هـــــ تكوين مجموعات، وعرض معلومات

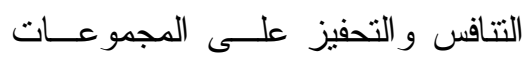

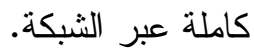


تعكس الحقيقة، وتركز النظرية السلوكية على جهود المتعلمين لتلقي المعرفة مــن العـالم الطبيعي و على جهود المتعلمين لنقله (جسـن

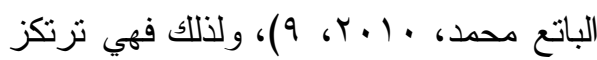
على الأنشطة التي تعزز التعلم كتغيير فـي ولي ولي

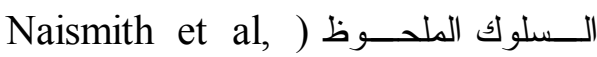
.(2004

ولأن محفزات الألعاب الرقمية تعتمد

بشكل أساسي على توفير التغذيــة الراجعــة الفورية على أداء المتعلم، ويرى أحمد عودة لؤل

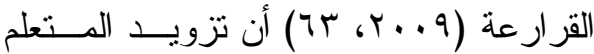
بالتغذية الر اجعة المناسبة تساعده وتوجهـهـ

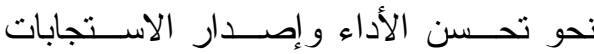

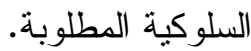

ويرى الباحث أنه لابـــــــن مـن إعــلام

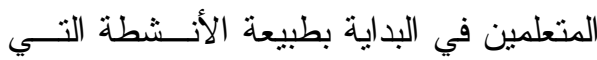

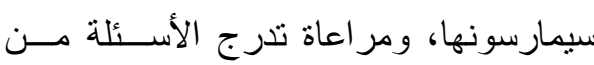

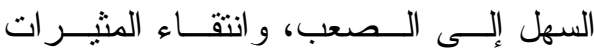
و الاستجابات المناسبة للحدث التعليمي، ويتم

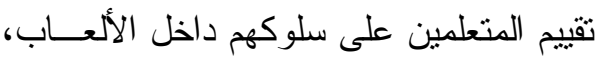
وأن ينم النقويم في ضوء أهداف محددة، وأن

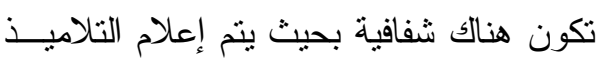
بطبيعة التحفيز الذي سيلقونه داخـلـل اللعبــة بالإضـافة إلى الناتج المرغوب مــن عمليـــة تعلمهم.
الرقمية، ومن المعينات على ذلك قيـام المعلم بعمل مجموعة مــن المقــابلات

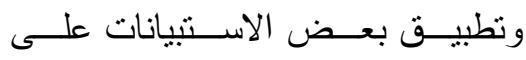

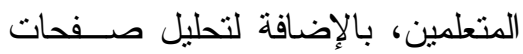

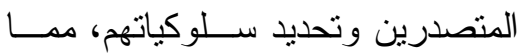
يساعد على تعـديل المـسـار بعـض وضل الثيء، وتطوير أسلوب تتفيذ محفز ات

$$
\text { الألعاب في التطبيق التالي. }
$$

النظريات التربوية التي تبنى عليها محفزات

$$
\text { الألعاب الرقمية: - مابة }
$$

تعتمد محفزات الألعاب الرقمية علـى

بعض النظريات التزبوية، و التي تتمنل فــي لني

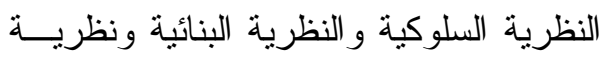

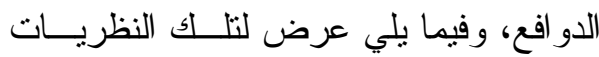
و التي تتمنل في:

النظرية السلوكية Behavioral Theory:

يحدث التعلم عنـــما يجــــ المــتعلم

التعزيز المناسب، أي عندما يحدث ارتبــاط Smith \& Regan, ) بين مثير و اسـتنجابة

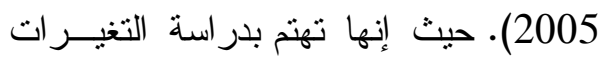
في سلوك الظاهرة، مقابل التغيــرات التــي تحدث داخل العقل، ويفهم التعلم علــى أنـــه

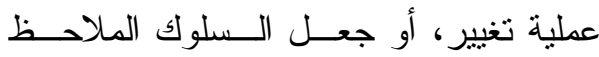
شرطيا نتيجة للتعزيز الانتقــائي لاســـــابة الفرد للمثير ات التي تقع في البيئة، وينظـــر للعقل كو عاء فارغ ينبغي أن يملأ أو كمــر آه 


\section{نظرية الدافع Motivation Theory:}

Prensky, 2001, ) يرى برينـسكي

1-5 أن الدافع للتعلم من أهم الأمور التـي بـ

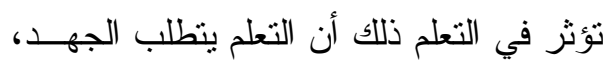

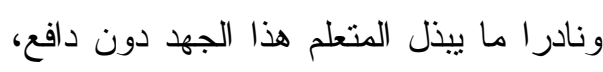

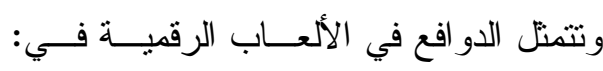

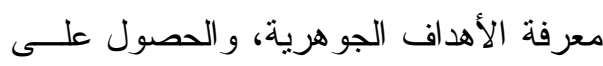

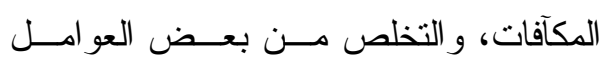

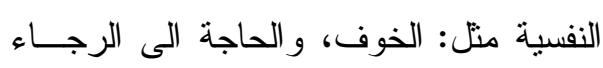

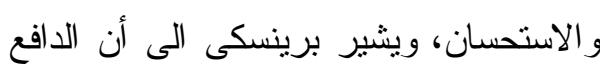

في الألعاب الرقمية يمكن أن يكون:

- الرغبة في اللعب لساعات طويلة.

$$
\text { - الرغبة الدائمة في الفوز المستمر . }
$$

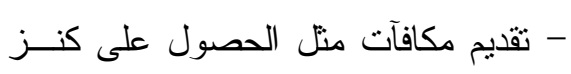

او تجميع نقاط.

- العمل، و التفكير ، وصنع القــر ار مــن التصن

الأشياء التي تدعم الدافع الذاتي.

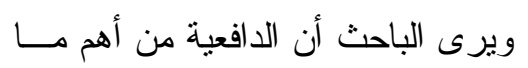

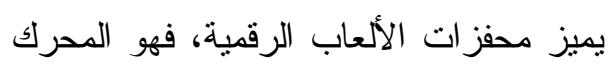

الأساسي لاستمر ار التلاميذ في التعلم، ويزيده

التتافس القائم بين التلاميذ في حل الأنـشطة لانشة

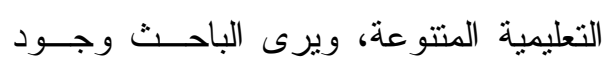

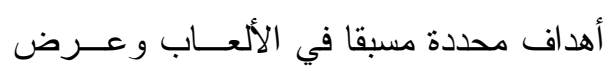

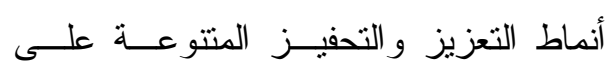

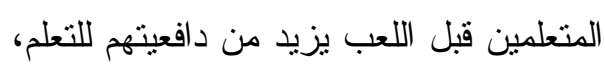

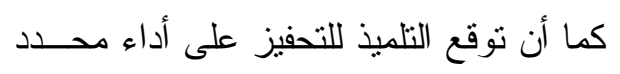

\section{Constructivism النظريــــة البنائبــــة}

:Theory

Constructivism تعد النظرية|البنائية

من أهم نظريات التعلم الحديثة، ويعد جـان

بياجيه Jean Piaget مؤسس البنائية فــي لفي

العصر الحديث؛ حيث يرى أن التفكير عملية

تتظيم وتكيف، ومن خلال هاتين العمليتـين

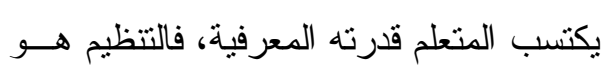

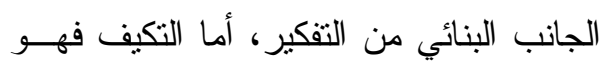

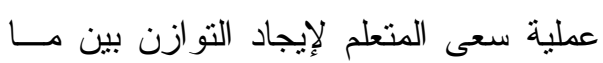

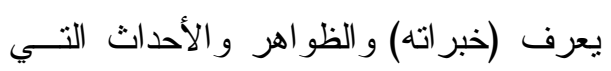

يتفاعل معها في البيئة. (محمد عطية خميس، ولنو

(rV-ru, r...r

ويرى الباحث أن محفزات الألعـاب

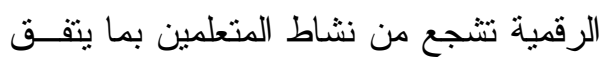

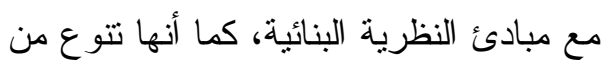

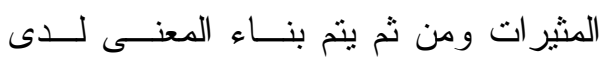

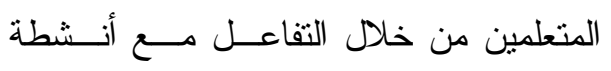
محفزات الألعاب الرقميــة و الانتقــال مــن

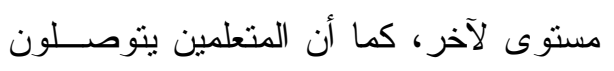

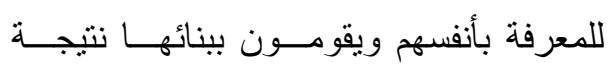

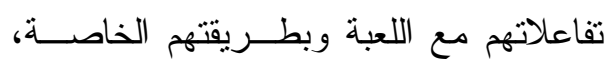

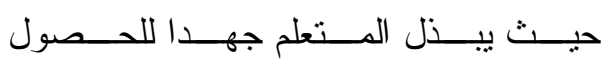

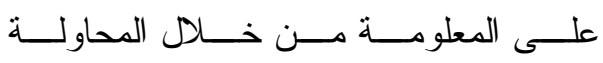
و الخطأ و التتافس مع الأقران ومن ثم بقاء أثر تعلمها. 
ولهذه النظرية آليات تحفيزية تستهدف

تلبية الاحتياجات النفسية، و والتي تتمنل فـئي

(Sailer et al, 2013)

(أ) من الممكن أن يكون هنــالك دافعيــة

وتحفيز لاى المتعلمين عند شــعورهم

بالمهارة المرتفعة في القيــام بمهــــة

\section{معينة.}

(ب)تتولد الدافعية و التحفيز لاى المتعلمين

عند شعور هم بالتحكم الذاتي والداخلي

$$
\text { عند التعلم. }
$$

(ج) تزداد الدافعية لدى المتعلمـين عنــــ

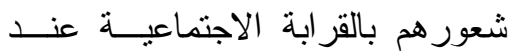

التعلم.

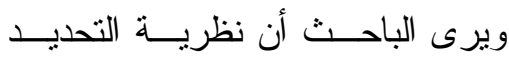

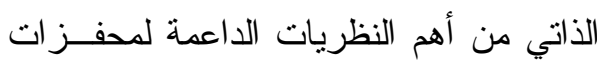

الألعاب الرقمية، فهي تهنت بتتميــة دافعيــة

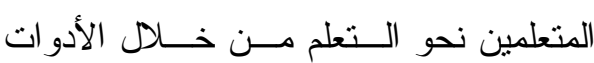

التفاعلية المتضمنة بمحفز ات الألعاب الرقمية

و الني تدعم شعور المتعلمين بالمهارة العالية

في القيام بالمهام التعليمية و لا سيما المرتبطة

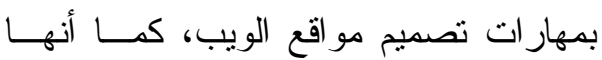

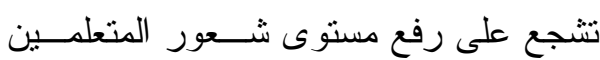

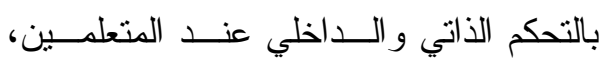

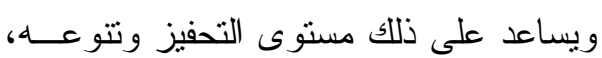

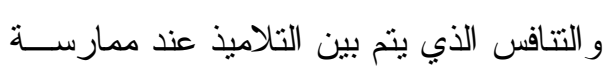
الأنشطة التفاعلية من خلال محفز ات الألعاب
يعمل على زيــادة نــشاطه، وســعيه نحــو الحصول على ذلك التحفيز المرغوب.

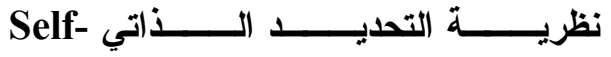

:Determination Theory

تهنت نظرية التحديد الــذاتي بوصــف

سلوك الأفراد من خلال قياس مدى ارنبـــاط

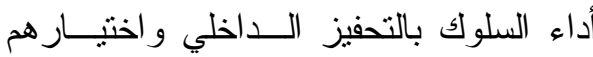

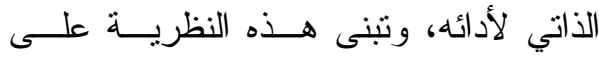
الدافعية والإتجاهات الثخصية، وهي تهـتن بوصف نمو التوجهات الطبيعية والحاجـات النفسية لدى الأفر اد. وتصف الأسـباب ور اء

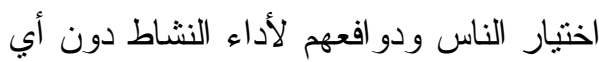

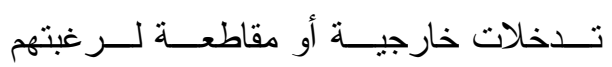
الداخلية. (Legault, 2017, 1) ومن ضمن إحدى أهم مبــادئ هــــه النظرية، هي النظرة المعاكسة لدور الحــافز

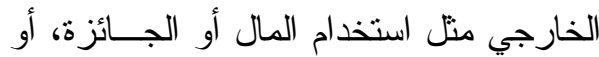

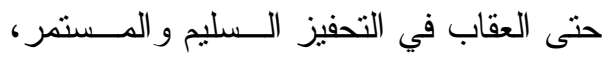

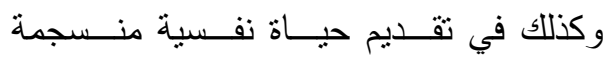

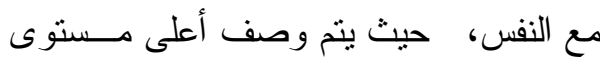

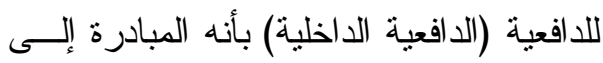

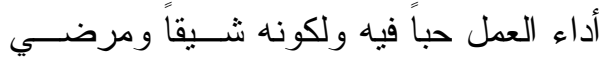

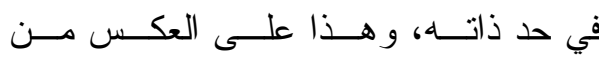

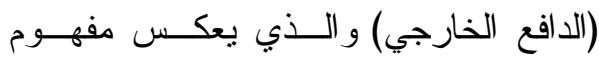

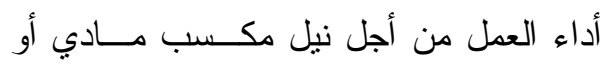

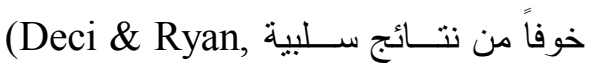
.2001, 487) 


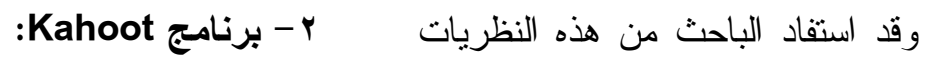

يشبه إلي حد كبيــر

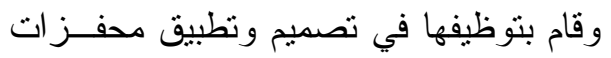

يعتبر ذا شعبية كبيرة بين المتعلمين، وهــو الألعاب الرقمية على تلاميذ الحلقة الإعدادية،

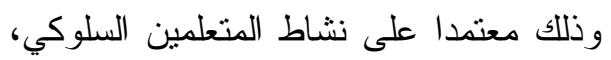
و البناء على معــارفهم ومهــار اتهم الــسابقة و التركيز على دافعيتهم نحو التعلم والاهتمام

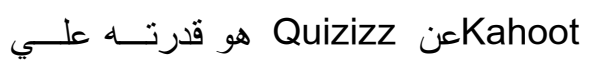

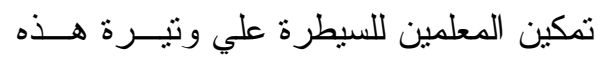

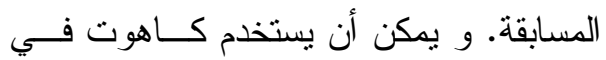
الفصول الدراسية بطريقة سهلة و ممتعة جدا

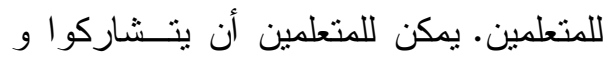

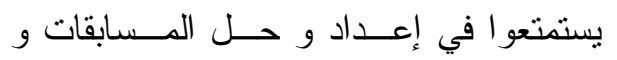

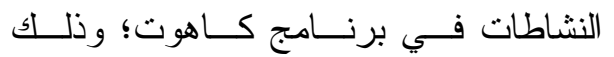
باستخدام أي جهاز ذكي لديهم أو منوفر فـي

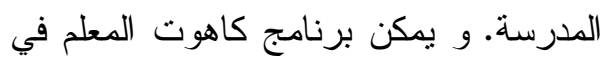

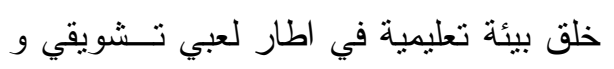
تتافسي.

الترخيص: هـــو برنـــامج مجــاني. رابـــ https:/kahoot.com البرنامج:

\section{r- برنامج Classcraft:} ودور المعلم فى هذا البرنامج يقتصر على تتغيل اللعبة، وتحديد نقاط الجائزة بناء علي مشاركة المتعلمين، و الاتتهاء بنجاح من لن

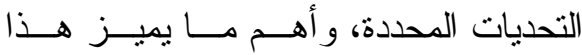

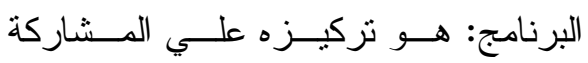
الجماعية وتتجيع المتعلمين، وهو يعتبر أداة

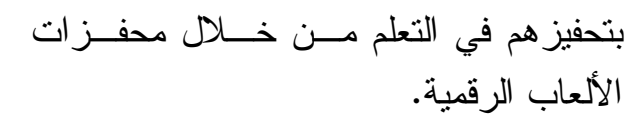

أدوات وتطبيقات محفزات الألعاب الرقميــة في التعليم:

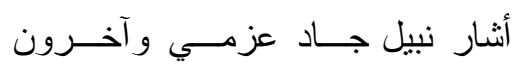

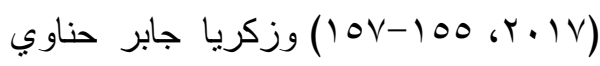

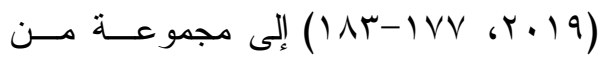

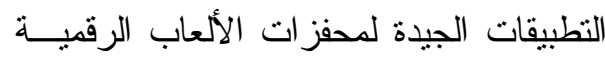

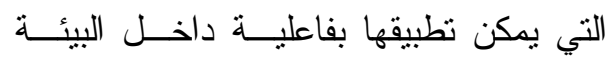

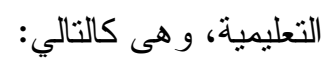
ا- برنامج Quizizz: هو برنامج يسمح للمعلمـين بتـــوفير

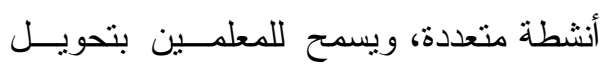

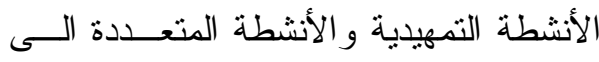

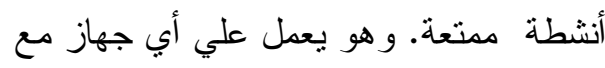

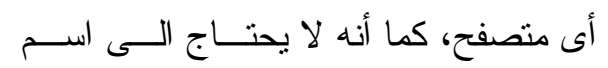

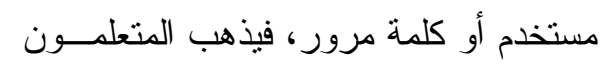

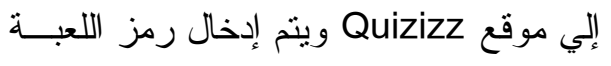
التي يقدمها المعلم وبمجرد انتهاء المـسابقة

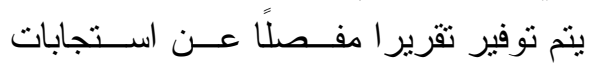
المتعلمين التي يمكن تحميلها وحفظها.

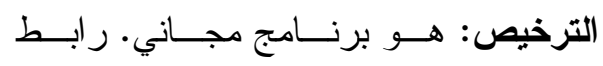

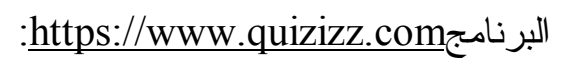


المحور الثاني_تصميم المواقع الويب:

يتتاول هذا المحور التصميم التعليمسي

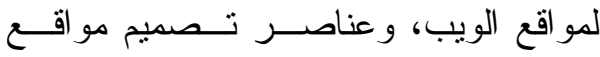

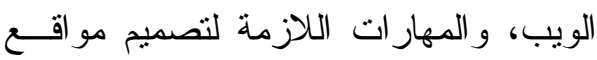

الويب، وفيما يلي عرض لذلك المحور :

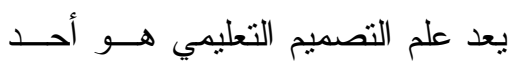

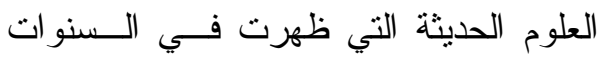

الاخيرة من القرن العشرين في مجال التعليم،

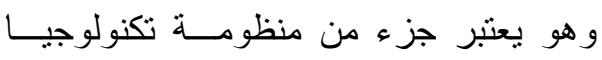

التعليم، وتطور مفهوم التـصميم التعليمسي دئي

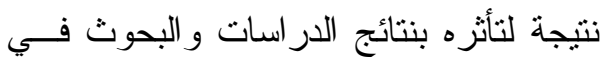

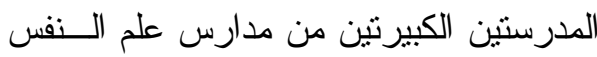
و هما المدرسة السلوكية، و المدرسة المعرفية،

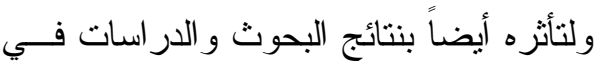
مجال التعليم، وكذلك التعليم المبرمج الـــي لــي كان له أكبر الأثر في ظهور نماذج مختلفــــة

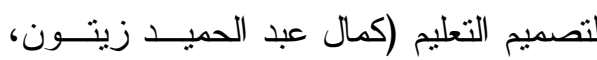

$$
\text { . (0.- }-\varepsilon V \text { ، Y.. ¿ }
$$

ويرى الباحث أن التصميم التعليمسي

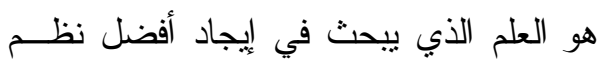

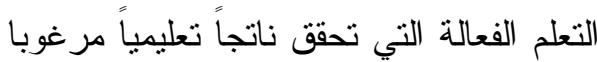
فيه، وفق شروط معينه لدى عينه محسـدودة

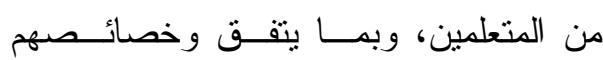
الإدر اكية مع وضع تصور لهذه الطرق فـي وني وني

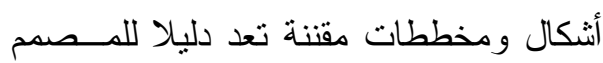

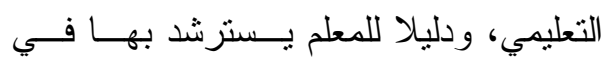

قوية لتغيير الطريقة التي يتفاعل المتعلمــون بها مع المحتوى ومع بعضها البعض.

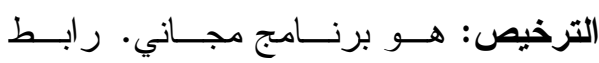
http://www.classcraft.com البرنامج: ؛ - برنامج Class Dojo وهذا البرنامج يعتبر الاختبار الأفضل

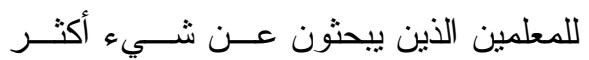

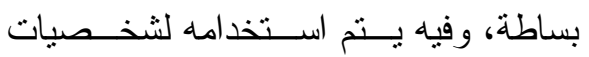

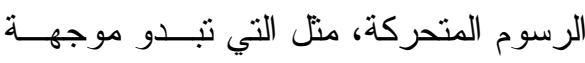

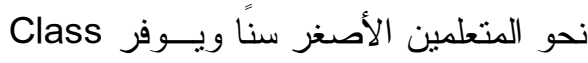

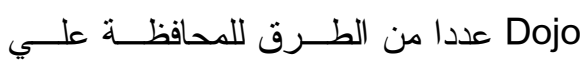
التو اصل مع المعلمين و المتعلمــين و أوليـــاء الأمور حيث يوجد ثقارير تفيد عـن مسـسار تقدم المتعلم ومجموعة متتوعة من وســائل التو اصل بما في ذلك ميزة نظام الرسائل في مني

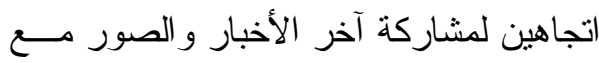

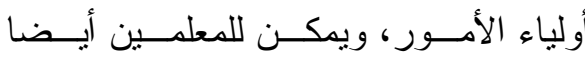
الحصول علي تتبيهات للرســائل مــن قبـــل

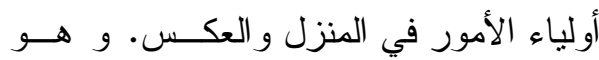
تطبيق بساعد على إدارة الفصول الدراســية

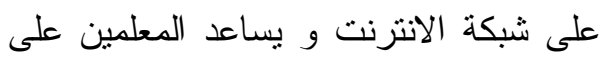

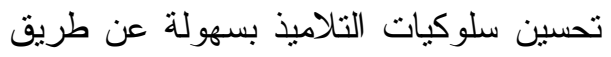
عرض السلوكيات المراد تتميتها و مقارنتها

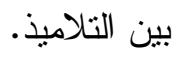

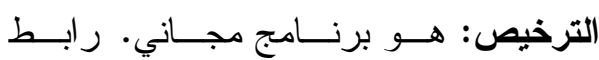

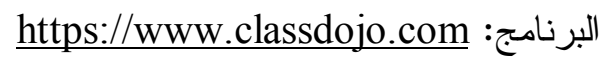


• النص و الرسوم الخطية: يعتمد وضوح

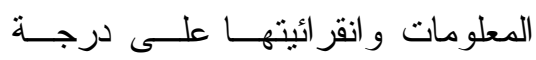
التمايز البصري بين حجم الخط، وكتل

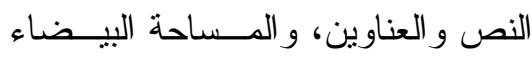

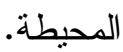

اختبار برنامج تأليف الويــب: تـشتنمل بر امج تأليف الويب على مميزات جديدة لا نتطلب مهار ات في البرمجة، ويجب اختبار اللغات الأكثز ملائمة، و القــدرة على مساعدة المصمم في تحقيق أهدافه. مبادئ تصميم صفحات الويب:

Jackson, 2009, ويرى جاكسون (24-16) أن عمليـة التصميم تـشمل العديـد

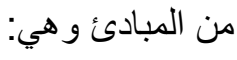

مالتخطيط Planning: وهي أول خطوة في تصميم صفحات ويب فعالة، فــانت

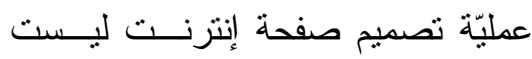
عمليّة عشو ائيّة، فالتخطيط الجيد يساعد

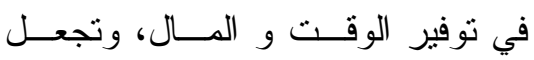

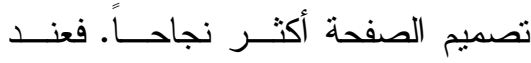

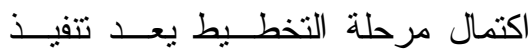
الاستر اتيجية سهلة وو اضحة الى حـد

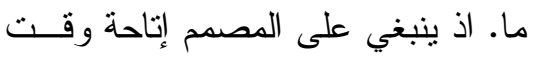
كافي للتخطيط و النطوير ، وأن يفكّر

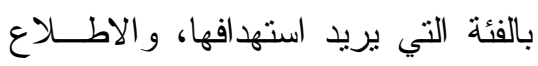

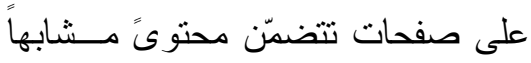
لما يُر اد تصميمه ليعرف كيف صممها

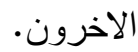

عناصر تصميم مواقع الويب:

Ruffini,2000,58-) يرى روفينـي

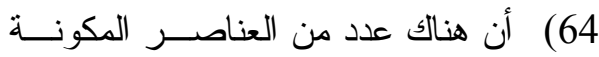
لعملية تصميم مو اقع الويب، و التي تتمنل في:

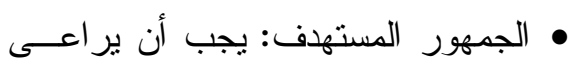
الموقع التعليمي حاجــات مـستخدميه،

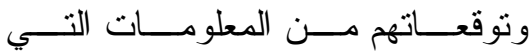
يدرسونها، ويبحثون عنها. • الأهداف: تعد كتابة الأهداف التعليميــة

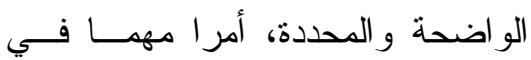
عملية التخطيط و التصميم. • Home صفحة البدايــة و المحتويــات Page and Contents يتضمن موقع الويب صفحة بداية العمل Home page

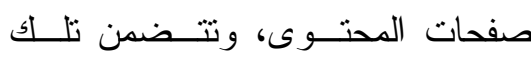

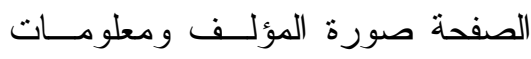
عنه. ( ) • بيئة تصفح الموقع: يجب أن يتم التتقــلـ

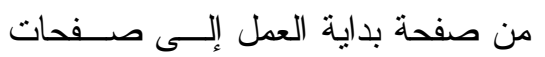
المحتوى بشكل غير خطي. • تصميم الــصفحات: ينبخـي أن تتبــع

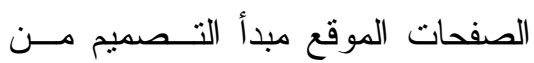
حيث البساطة و الوضوح، و التتاسق في

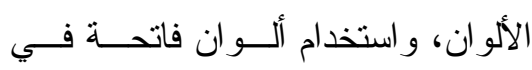

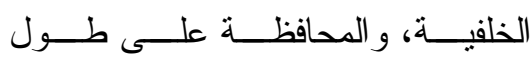
الصفحات لسهولة التحميل. 
- قابلية الاستخدام Usability: و تتمثــل

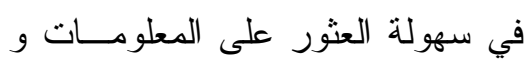

معالجتها.

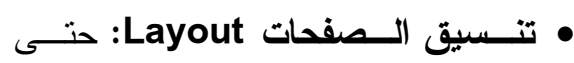

يضمن المصمم راحة المستخدم أثتــاء

تجوّله في صفحة الإنترنت، وضــــمان

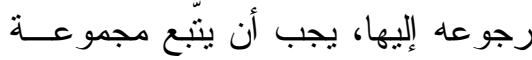

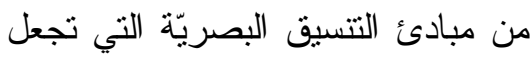

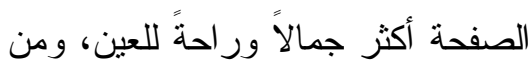

أهمّها:

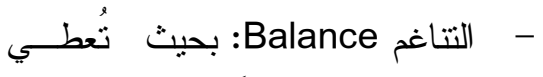

الصفحة إحسـاساً بالنتاســق بــين

$$
\text { عناصر ها. }
$$

-

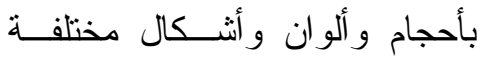

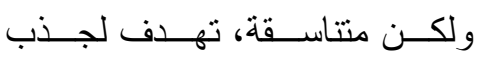

المشاهدين.

-

إعطاء لون أو شكل أو حجم مميّز

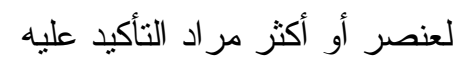

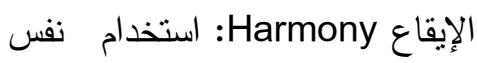

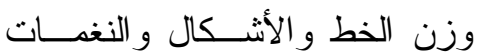

بحيث تتو افق بشكل جيد.

- -

من أن القر اعة تتبع مسار ا محـددا، وهـا،

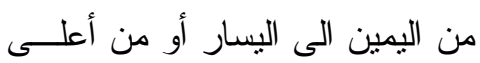

$$
\text { الى أسفل على سبيل المثنال. }
$$

• التصميم البصري Visual Design:

بتضمتن التصميم البصريّ مجموعة من البصري

المبادئ من أهمّها:

- الوضوح legibility:

الخلفيّات كثيرة الزخارف، أو النصوص لبوح

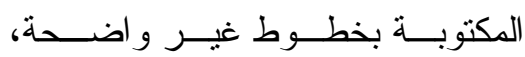

والأنسب هو استخدام خطوط شـــائعة

ومناحة على جميع الأجهزة.

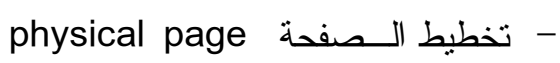

layout

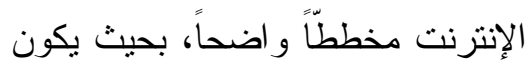

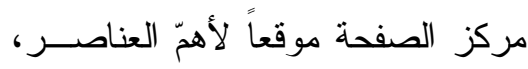

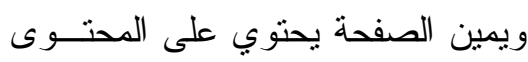

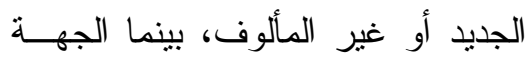

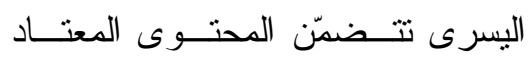

و التقليديّ.

- الحيّز الفارغ Spatiality: إنّ التصميم

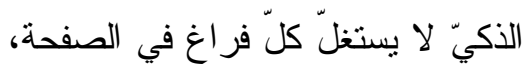

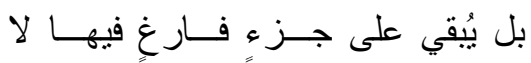

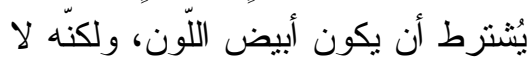

يتضمّن محتويات رئيسيّة.

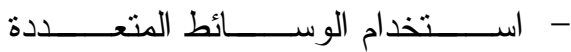

Multimedia

الرسوم المتحركة و الصوت و الفيــديو

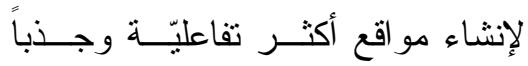

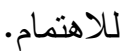


و الارتباطات التشعبية ، و الجداول ، ونشر

كما قام الباحث بالاطلاع على كتــاب

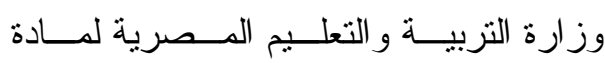

الكبيونز وتكنولوجيا المعلومات المقرر على ولى

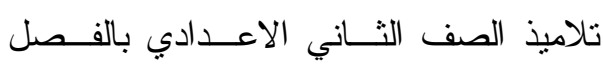
الدراسي الأول، و التي تضمنت مجموعة من الجو انب المعرفية، و الأدائية لمهار ات تصميم

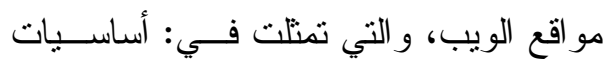

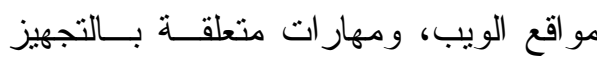
لتصميم و إنشاء مو اقع الويب وتصميم و إنثاء

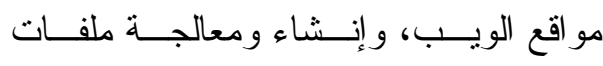

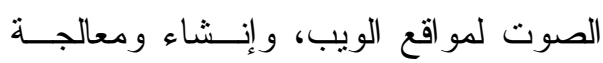

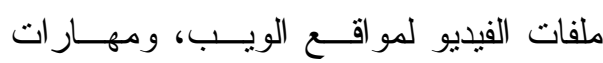

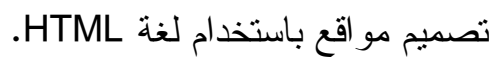

وفي ضوء ما تم تحليليه من البحوث

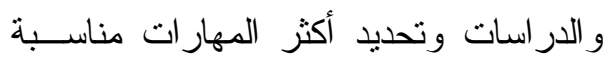

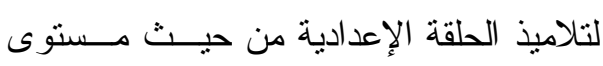

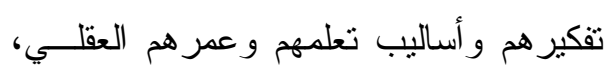

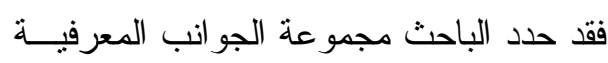

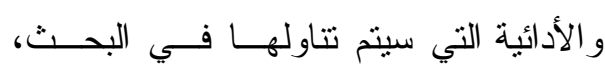
وستعرض بشيء من التقصيل في إجراءات

البحث. وسنعز

المحور الثالثـ التفكير البصري:

ينتاول هذا المحور مفهــوم التفكيــر

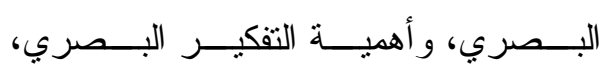

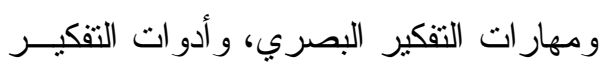

- - الوحدة Unity: وهــي أن جميـع

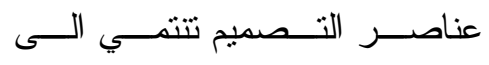

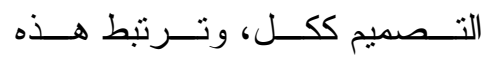

العناصر أيضا مع بعضها البعض. كان.

المهارات اللازمة لتصميم موقع الويب:

تعد مهار ات تصميم مو اقع الويب هي مي مئمي

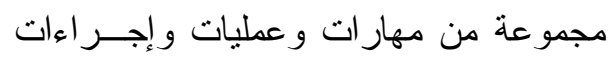

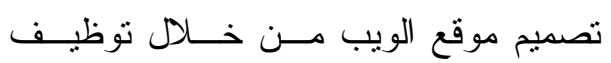

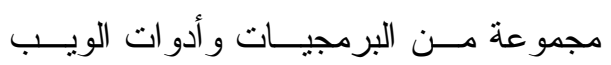
التفاعلية.

و اتفقت العديد من البحوث و الدراسات

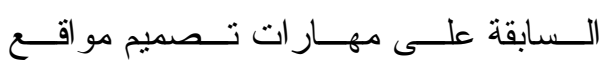

وصفحات الانتزنت، حيث أنثارت دراسة كل بل

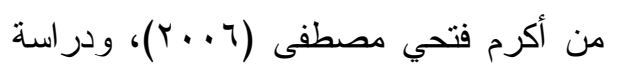

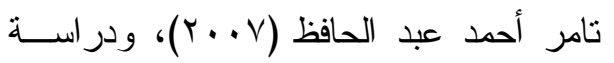

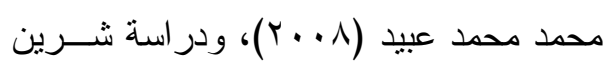

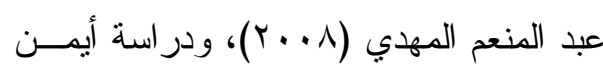

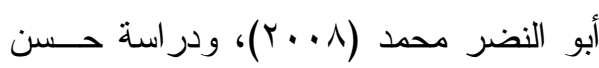

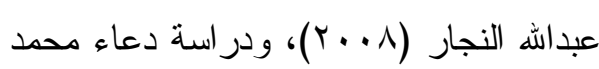

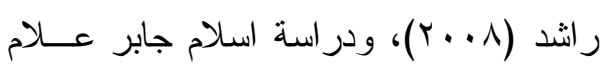

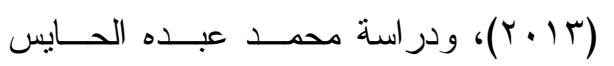

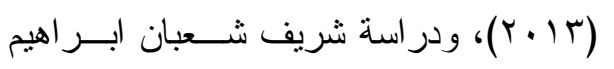

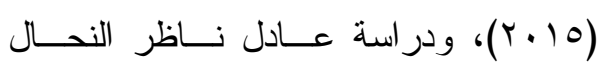

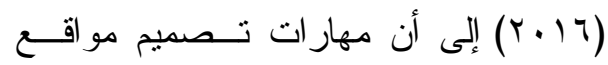

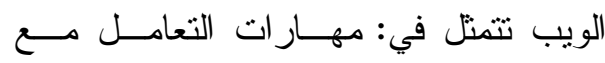

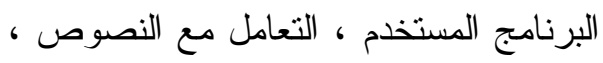

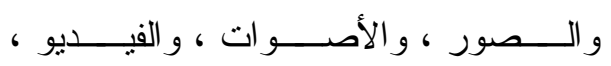


r. التحكم و الــضبط الــذاتي ومتابعــة

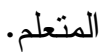

r. معتقدات المتعلم وحدسه فيما يتعلــق

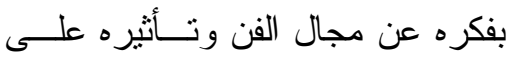

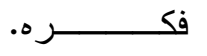

ويرى الباحث أن القدرة على التفكيــر

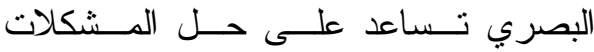

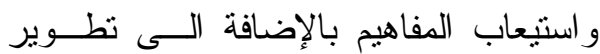
المهار ات بشكل عام، ولا ســيما مهــارات بـات لاتهات

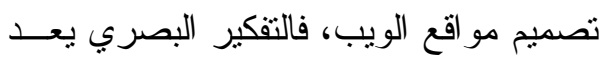

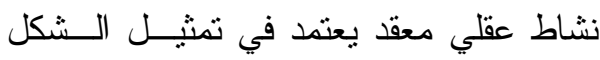

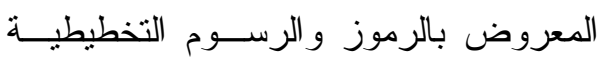

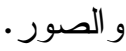

كما أن التفكير البصري يساعد علـى

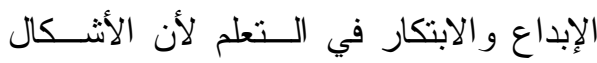

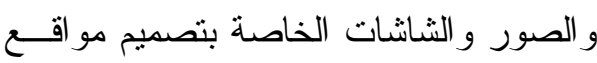
الويب المعروضة على المتعلم في الموقــف

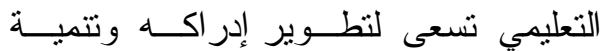
مهار اته، وبالتالي يساعدهم على الابتكار في

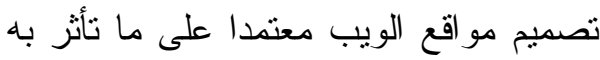

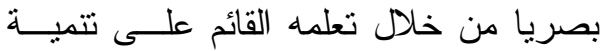
مهار ات التفكير البصري. وترى فداء الـشوبكي (• (•r، مب)

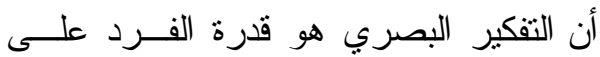

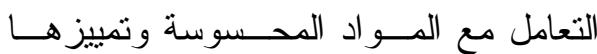

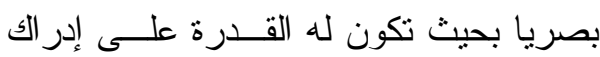
العلاقات المكانية وتفسبر المعلومات وتحليلها
البصري، وفيما يلي عرض لذلك بشيء من

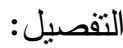
مفهوم التفكير البصري: - م يعد التفكير البصري مــن الأســاليب

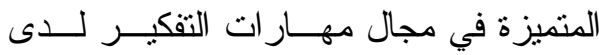
المتعلمين، فهو يعتمد علــى ترجمـــة اللغــــة

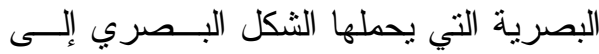
لغة لفظية مكتوبة أو منطوقة، وذلك من أجل

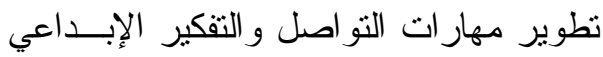
و المنطقي التي تحقق ثقة المتعلم في التعامــلـل

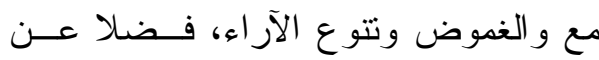
تطوير الإدر الك من خلال المناقشات التي نتم عبر عملياتها لتتمية الممارسة الجمالية.

و هناك علاقـــة تنبادليــة بــين البنيـــة

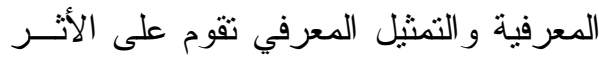

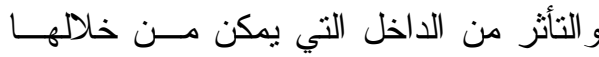
تمثيل المعرفة (فتحـــي مــصطفى الزيــات،

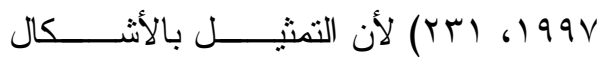
البصرية يدعم التفكير البصري مــن ناحيــة

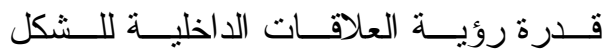
المعروض، وقدرة الكثف عـنـ العلاقــات

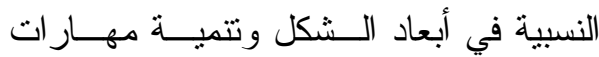

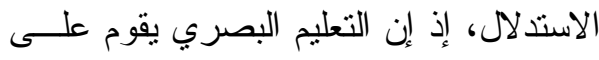
المعرفة ويرنبط بثلاث أصناف من السلوك: (وليم عبيد، وعزو عفانة، r... T، (9) 1. معرفة المتعلم على فكره الثخــصي ومدى دقته في وصف تقكيره. 
- - يعتبر التفكير البصري مصدر ا جيــدا

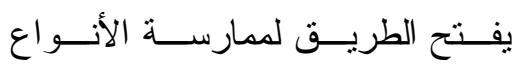
المختلفة من التفكير مثل التفكير الناقد

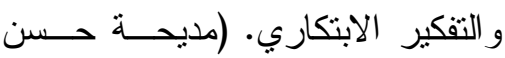

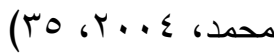
- - تتمية القدرة على التصور البـصري

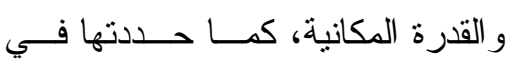
مجموعة من ورش العمل التي قامت

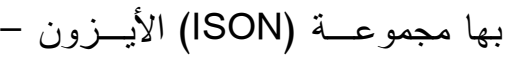

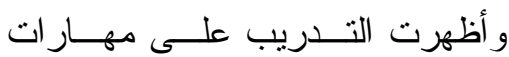
التصور البصري يساعد في تحقبــق

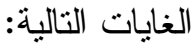

• تحقيق الاتصسال الفعال بين أعضاء

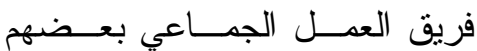
بعضا. • تتمية القدرة على الاكتهـشاف وتقــدير

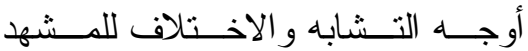
البصري من خلال الرؤيـــة المختلفـــة لأعضاء الفريق.

• تتمية القدرة على إنتاج مزيد من الحلول

$$
\text { المبتكرة. - مانه }
$$

الرؤية الكلية للثيء بدلا من النظر إلى

(Blair, 2003, 89-90). التفاصيل ونظر اللدور المهم الذي يلعبه التفكير

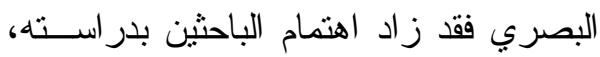

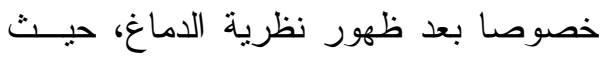

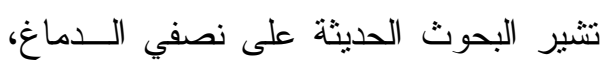

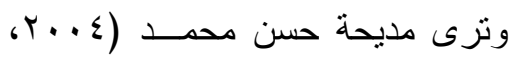

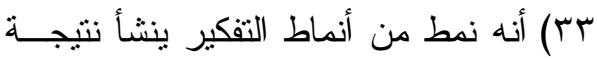

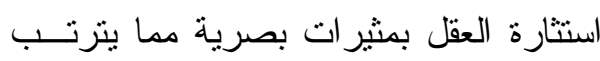

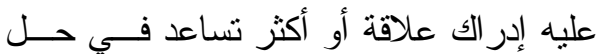
مشكلة ما أو الاقتر اب من الحل.

ويرى الباحث أن التفكيــر البـصري

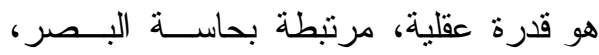

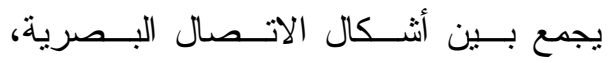

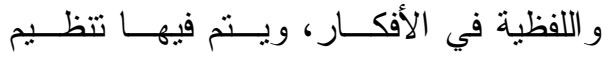

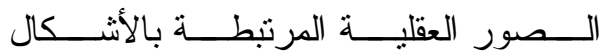

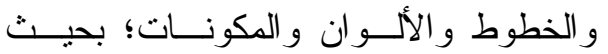
تساعد المتعلم في الحصول على المعلومــات

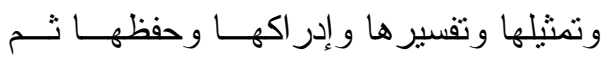

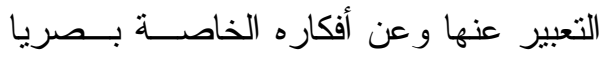

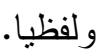
أهمية التفكير البصري يقوم التفكير البصري بدور مهم فـي

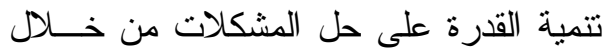

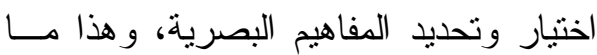
أطلق عليه" ذكاء الإدر الك " Intelligence of Perception في (Longo, 2001)

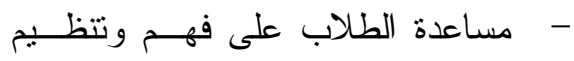

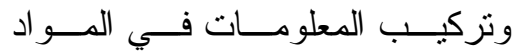
الدراسية، ومساعدتهم علــى تتميــة القدرة على الابتكار و إنتــاج الأفكــار

(Blair, 2003) (الجديدة) 
أنه توجد طريقتــان مختلفتــان ومتكاملتــان أدوات التفكير البصري:

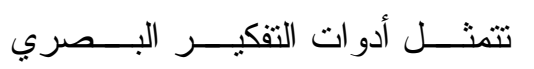

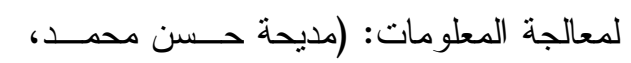
في الأساليب و الطرق المستخدمة في التمنيل $(\varepsilon \cdot 6$. . . $\varepsilon$

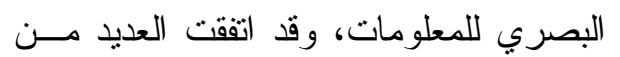
البحوث و الدر اسات على أن أدوات التفكيــر

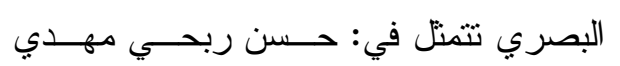

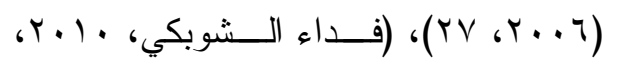

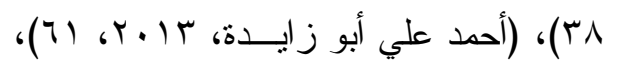

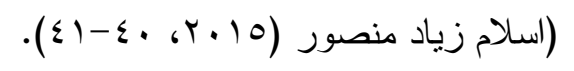

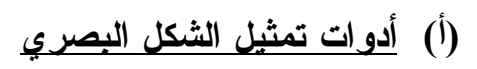
ا. الصور : وهي الطريقة الأكثر دقة فــي الصئي

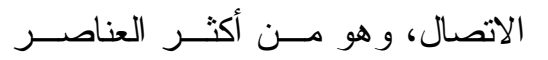

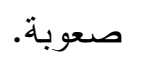

Y. الرموز : وهي الأكثر شيوعا و استخداما بالرغم من أنها أكثر تجريدا، وتمثنـل بالكلمات.

r. الرسوم التخطيطية: وهي المـستخدمة

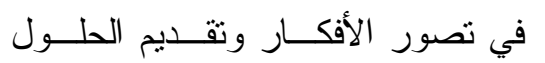
المثالية، سواء كانت الرســـوم متعلقـــة بالصور أو بالمفاهيم. ـ. العروض الكمبيوترية البصرية: وتتمنل فئل في العروض الكمبيوترية ثنائية وثلاثية الأبعاد بالإضافة للرسوم المتحركة. (ب) أدوات معالجة المعرفة بصريا:

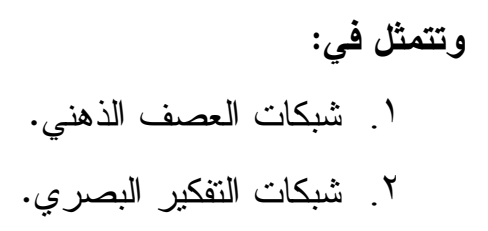

الطريقة الأولى: خطية تسير خطــوة

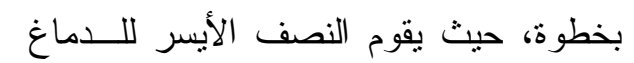
بتحليل الأجز اء التي تثكل النموذج أو النمط.

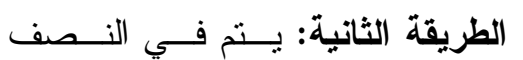
الأيمن من الدماغ وتعمل على إيجاد العلاقات

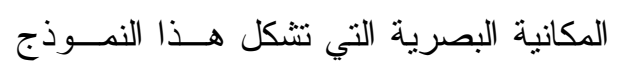
وتزداد عندما يمارس الفرد التفكير البصري.

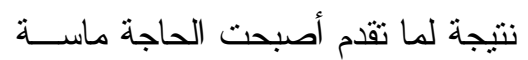
إلى تدريب المتعلمين فــي مر احسل التعلــيم

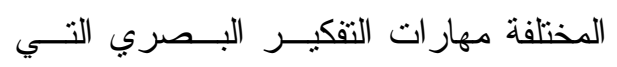
استخدمها هؤلاء العلماء البارزون المتمتلــــة

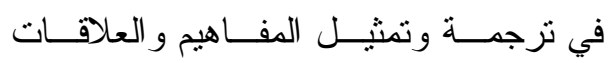
المجردة اللفظية بأثكال بصرية. ومما سبق يتضح أن للتفكير البصري

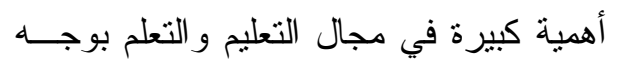

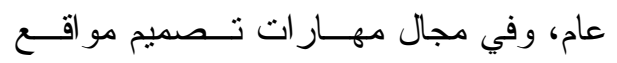

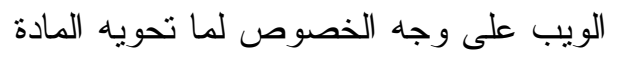
من مجموعة من المعارف و المهار ات، و التي تحتاج للمزيد من التخيل البصري، كما أنهــا تعتمد على التذكر من خلا لصنئ الصور المنتوعة

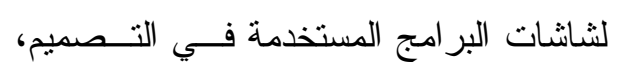

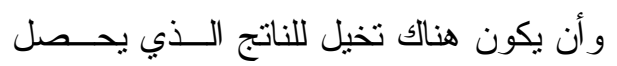

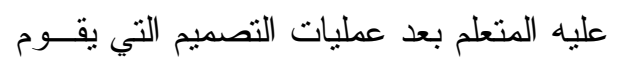
بها. 
و المتابعة البصرية اعتمادا أساســيا، وفيهــا تتحول المهارة إلى معنى يستقر في الــــهن ويمكن التعبير عنها سلوكيا.

Visual

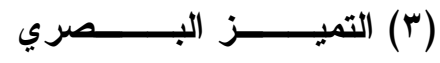

\section{Discrimination}

تعتبر المهارة الأساسية الأولـى فـي

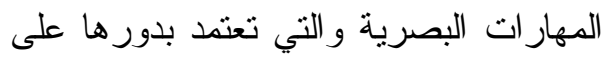

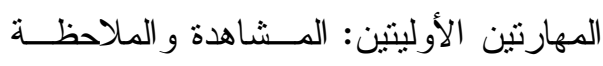

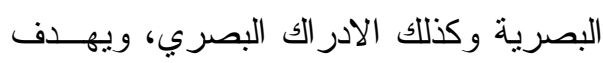

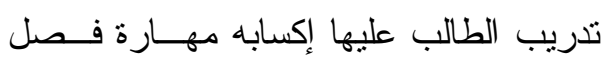

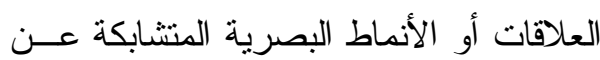

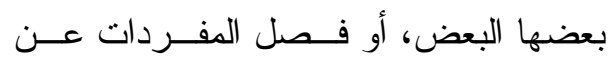
وسطها المحيط للتعرف على خصائص كـلـ لــل مفرد أو علاقة أو نمط بصري بشكل منفرد،

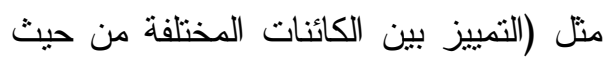

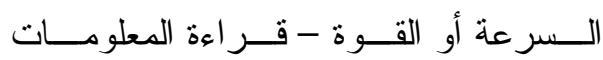
الموجودة على الأشكال بشكل صحيح).

Visual

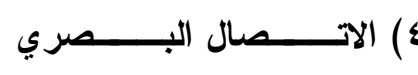

\section{Communication}

وهي المهارة الرابعة من المهــارات

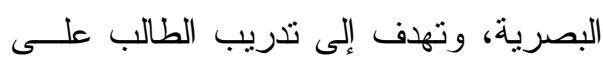
مهارة مر اجعة عمله أو قيامه بممارسة الرسم الفني أو التركيب البصري.

Observation الاستدلال البـصري Visual

تعتبر هذه المهار ات (البصرية) مسن

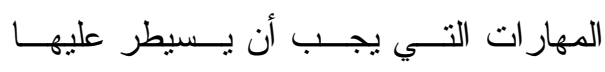

$$
\begin{aligned}
& \text { r. المنظمات التخطيطية } \\
& \text { ع. . خر ائط المفاهيم. } \\
& \text { مهارات التفكير البصري: }
\end{aligned}
$$

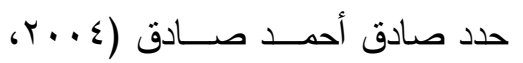

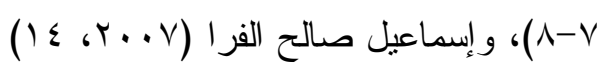

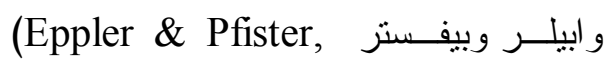

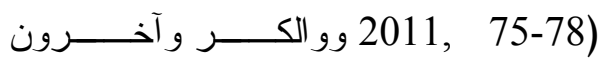
(Walker, et al, 2011, 21) للتفكير البصري وهي على النحو التالي:

Construction of الأكرة البصرية visual memory

و هي المهارة التي تعمل على تحويــلـ

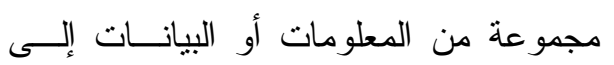

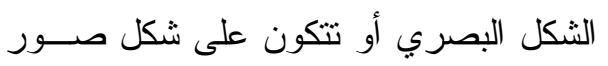
بصرية.

وتظل العلاقة بين الذاكرة البـصرية

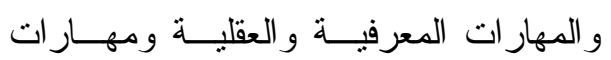
المجال النفس - حركي و المهار ات البصرية

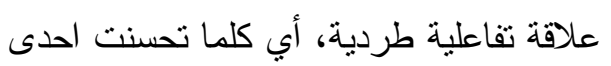

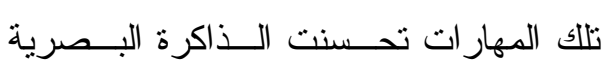
و العكس صحيح.

Visual (r) الإدر الك البـ (ب)

\section{Perception}

تعتبر من المهار ات البـصرية التـي

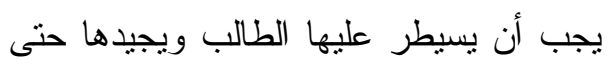

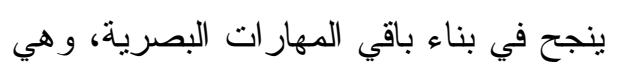

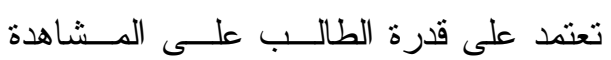


أفضل، كما أن مهار ات تصميم مواقع الويب

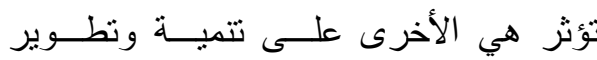

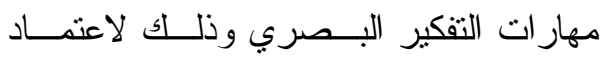

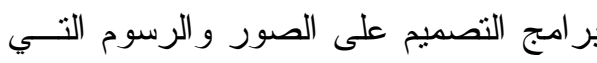
تساعد على تتمية مهار ات التقكير البـصري المختلفة، وعند تقديم تلك الصور و الرســوم و الاشكال و المعلومات المصورة من خــلال محفزات الألعاب الرقمية المعتمدة على تفعيل

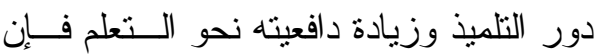
ذللك سبساعد على تحسين مستوى أداء وتعلم

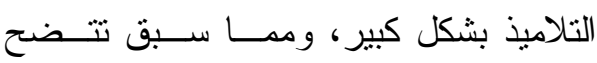

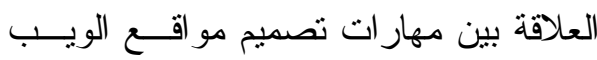

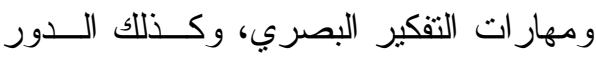

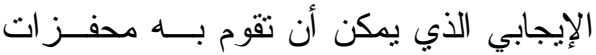

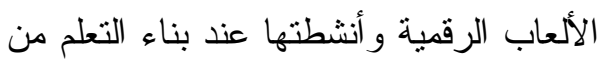

خلالها.

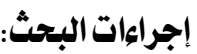

لبناء أدو ات البحث وتطبيق تجربتــه، قام الباحث بالإجر اءات التالية:

1 - مادة المعالجة التجريبية (بيئة التعلم) في ضو ء مر اجعة الباحــث للبحــوث

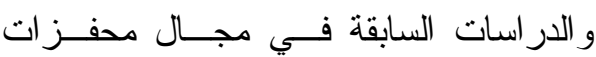

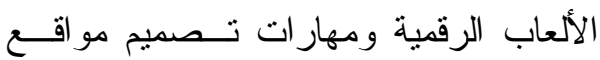

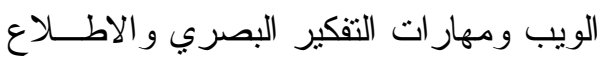

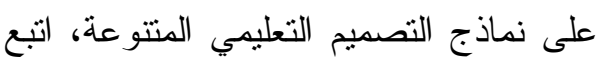

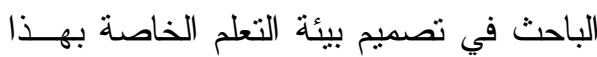

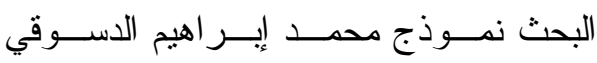

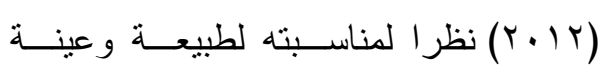

الطالب، ويجيدها حتى ينجح في بناء بـاقي

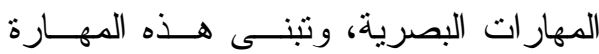
البصرية على القدرة على الاستدلال و التحقق من صحة الحلول بصريا، ومن ثم الاعتمــاد على حاسة البصر ، و الملاحظة في التعـرف على الأشياء بشكل صحيح.

( آ) التحليل البصري Visual Analysis و هي المهارة التي تساهم بشكل حيوي في تعرفه على الدلالات البصرية لكثير مـن فئن

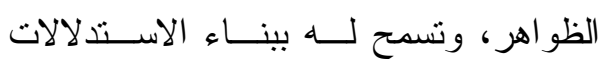

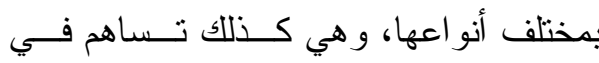
التعرف على مفاهيم بناء العلاقات و الأنمــاط

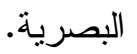

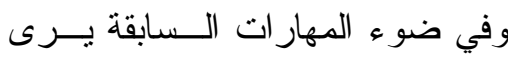
الباحث أن مهار ات التفكير البصري المناسبة

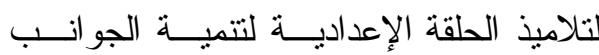

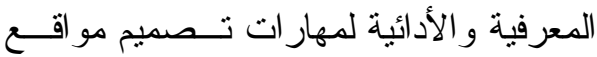
الويب تتمنل في مهار ات: الذاكرة البصرية،

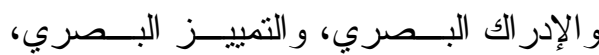

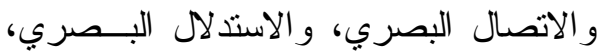

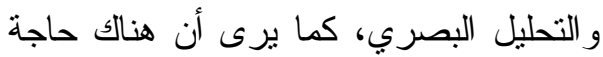

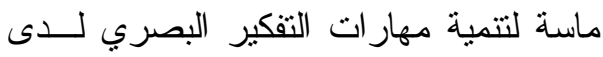

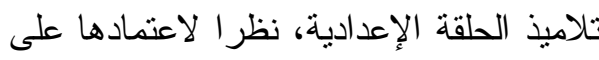

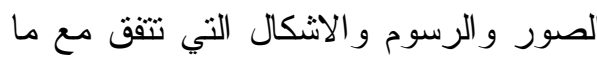

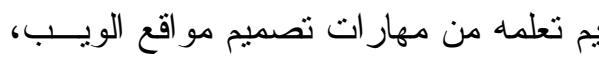

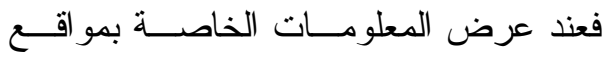
الويب على التلاميذ بشكل مرئي يساعد على لئ

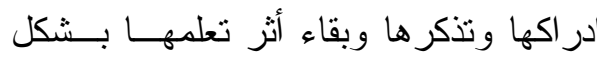




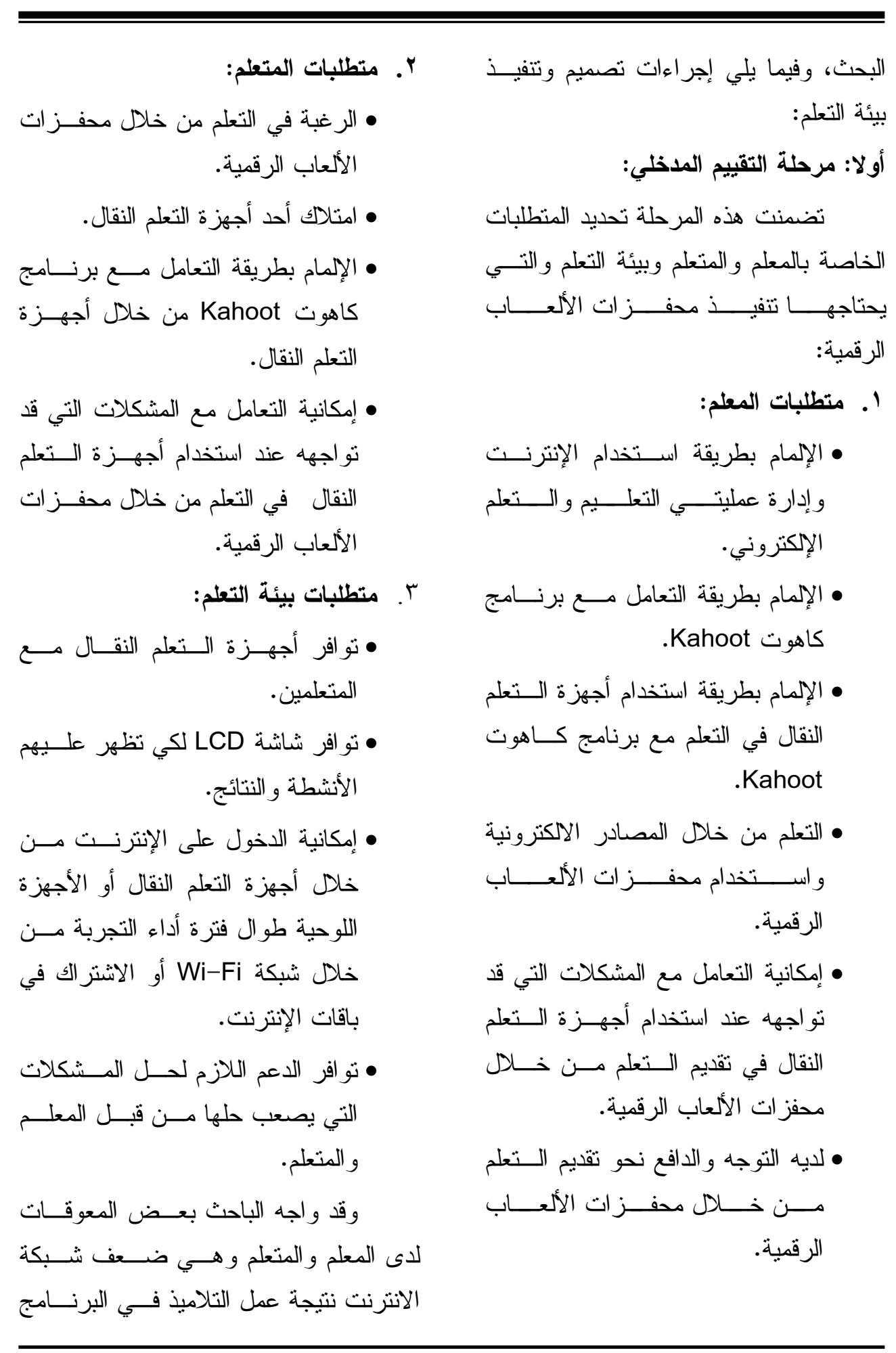




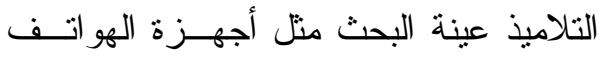

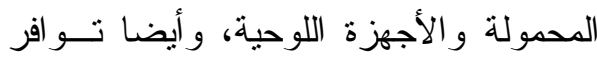

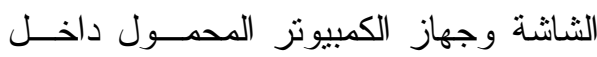
المدرسة. r. تحديد البنية التحتية التكنولوجية: ويتم في هذه الخطوة تحديـــــ البنيــة

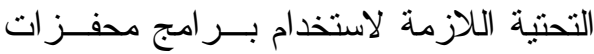

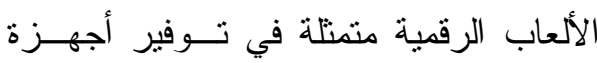

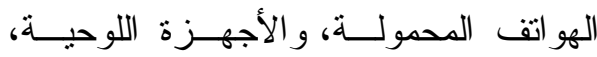
وجهاز الكمبيوثر المكتبي، وشاثة للعرض، وخط اتصال بالإنترنت بـسر عة مناسـبة أو ونئ باقة انترنت بسر عة مناسبة، ونوفير حسساب على موقع كاهوت Kahoot.it للتعلم عبــر شبكة الإنترنت، وقد قام الباحــث بإحــضار راوتر لا سلكي wireless router للأجهزة النقالة و الأجهزة اللوحية. ثالثا: مرحلة التحليل: وتشمل هذه المرحلة تحليل المحتــوى هرى التعليمي بالخطوات الثالية: ! . تحديد الأهداف العامة:

حيث قام الباحث في هذه الخطوة من

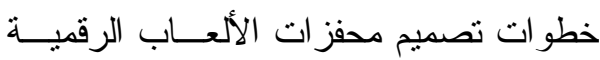
بتحديد الهدف العام للمحتوى التعليمي: وهو

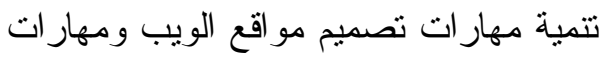
التفكير البصري لدى تلاميذ الحلقة الإعدادية

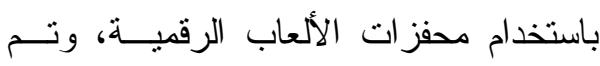

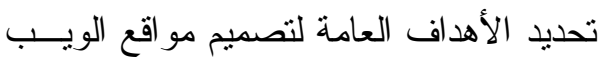

بنفس الوقت، وقام بالتغلب عليها برفع سرعة

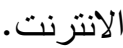
ثانيا: مرحلة التهيئة: وهي خطوة علاجية لمو اجهــة نقــاط الضعف لمنطلبات بيئة التعلم، وتتمل هـــه

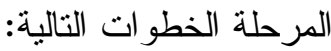

ا . تحليـلـل خبـرات المتعلمــين ببــرامج محفزات الألعاب الرقمية:

وتم في هذه الخطوة تحليـلـل خبــرات المتعلمين الخاصة بالتعامل مع أجهزة الــتـعلم النقال وبر امج الكمبيوتز ومواقع الويب التي بـي

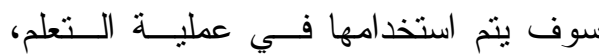

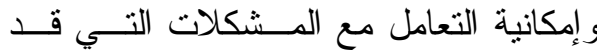

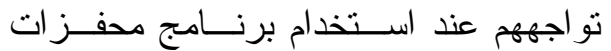
الألعاب الرقمية Kahoot وتو افر المهــار ات مندات اللازمة للاخول إلى شبكة الإنترنت و التعامل مع التطبيقات المختلفة الموجودة على أجهزة التعلم النقال، وقد قام الباحث بتدريب التلاميذ

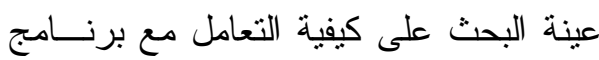
محفز ات الألعاب الرقية كاهوت Kahoot. r. تحديد المتطلبات الواجب توافرها فــي برامج محفزات الألعاب الرقمية: وتم في هذه الخطــــوة تحديـــــــــــع

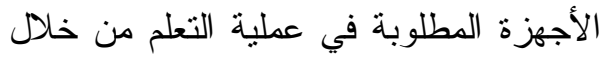
محفزات الألعاب الرقمية وهي أجهزة التعلم

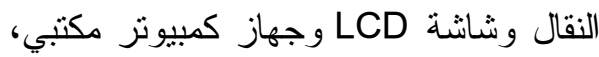
حيث تم التأكد من تو افر هذه الأجهزة لــدى وهي 


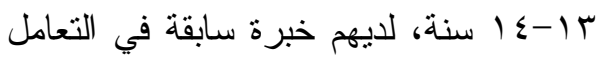

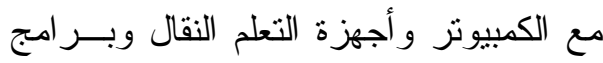
الانترنت.

خصائص شخصية: لاى جميع أفراد

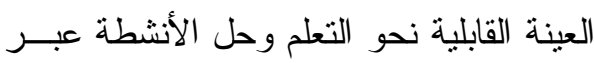

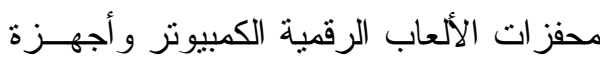

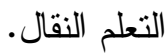

خصائص بلنية: تتمنل فـي ســلامة

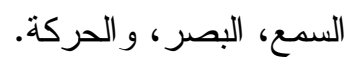

خصائص النمو: تتمثــل خــصائص النمو في هذه المرحلــة بــإدر الك المفــاهيم

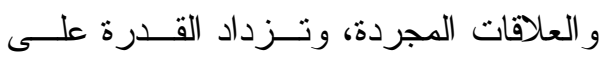

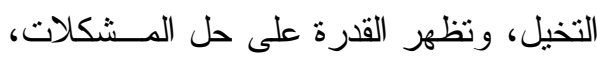

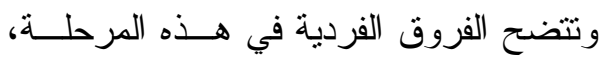
ويظهر الاختلاف في درجة القــدرة العقليـــة العامة، ونمو الميول و الاهتمامات، ويظهـر اهتمام التلميذ بمستقبله الدر اسي و المهني. رابعا: مرحلة التصميم: وتــشمل هــــه المرحلـــة الخطــــوات

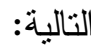

\section{ا ـ صياغة الأهداف الاجرائية:}

من خلال الهدف الرئيس للبحث قـام الباحث بصياغة، و اثتقاق الأهداف الإجرائية مر اعيا مجموعة من المعايير وهى قابليتهـــا

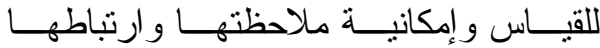
بالمحتوى التعليمي، وعدم التعــارض بــين

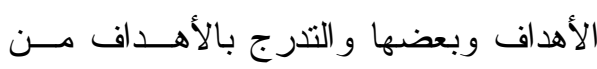

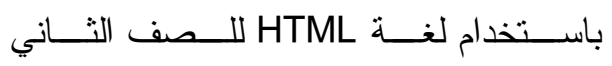
الإعدادي الفصل الدراسي الأول بحيث يكون التلميذ قادر ا على أن: • يفهم أساسيات مو اقع الويب.

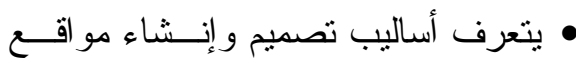

$$
\text { الويب. }
$$

• يقوم بإنشاء ومعالجة ملفــات الــصوت

$$
\text { لمو اقع الويب. }
$$

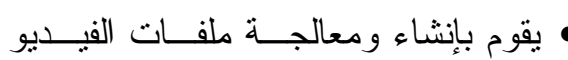

$$
\text { لمو اقع الويب. }
$$

• يتقن مهار ات تصميم مو اقع باستخدام لغة

.HTML

r. تحليل خصائص المتعلمين واحتياجاتهم:

تمثل هذه الخطوة أهم الخطوات حيث

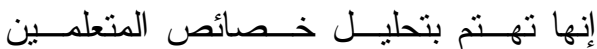
واحتباجاتهم لأن المتعلم بمتل حجر الأســاس لـاس في العملية التعليمية، ولذلك يجــب مر اعــاة

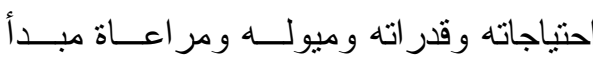
الفروق الفردية بين المتعلمين. خصائص المتعلمين:

خصائص عامة: تمنلت عينة البحــث

في تلاميذ الصف الثاني الاعدادي من الذكور و الاناث المقيدين للفصل الدراسي الأول للعام

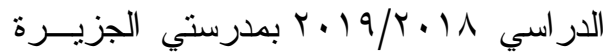
المشتركة للتعليم الأساسي و أطو اب الإعدادية المشتركة التابعتنين لإدارة الواسطي التعليمية الإسية - محافظة بني سويف. وهم اعمار هم بـين 
ذللك تم تحديد (0) نقاط رئيــسية للمحتــوى، وهى: • مأساسيات مو اقع الويب. • تصميم و إنشاء مو اقع الويب. • إنشاء ومعالجة ملفات الصوت لمو اقــع

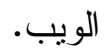
إنشاء ومعالجة ملفات الفيــيو لمواقــع

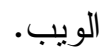

• مهار ات تصميم مو اقع باســتخدام لغــة .HTML

وتم الاعتماد على الأنشطة التعليميـــة

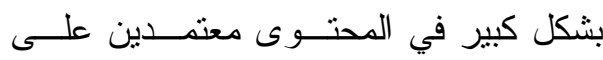

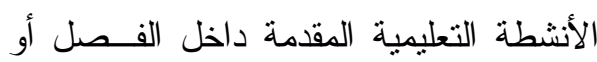
معمل الكمبيوتز عن طريق برامج محفــز ات التهبه

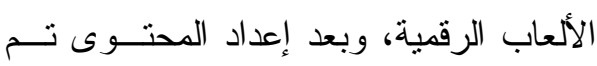
عرضه علـى مجموعــة مــن المحكمـين

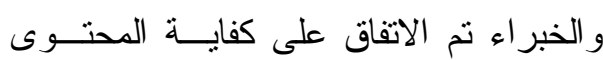

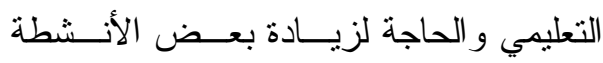

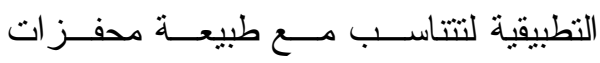

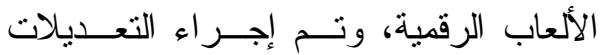

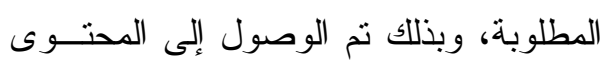
في شكله النهائي. ونتم الاعتماد في طريقــة محفـز ات الألعاب الرقمية على استخدام برنامج كاهوت

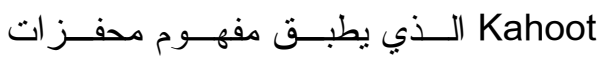

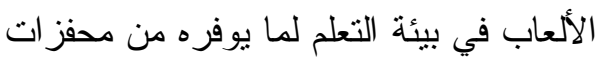

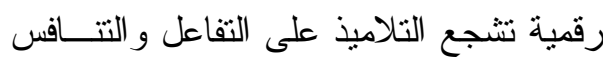

المستويات الدنيا إلى المستويات العليــا، وأن

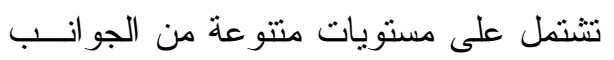

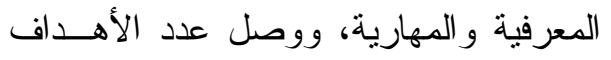
المعرفية إلى (0) أهداف رئيسة و (9 ب) هدفا ولها

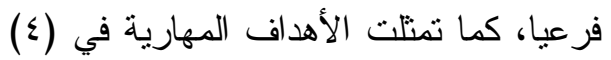

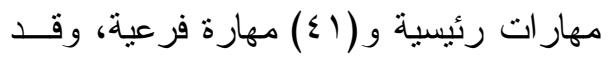
تم عرضها على مجموعة مــن المحكمـين

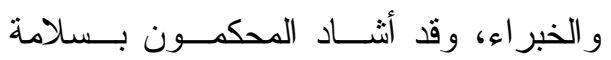

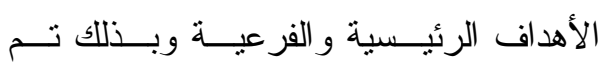
التوصل إلى قائمة الأهداف النهائية. r ـ تصميم المحتوى التعليمي: في ضوء الأهداف التي سبق تحديدها

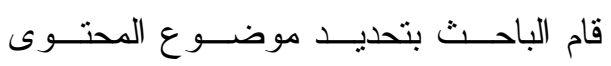
بالاستعانة بكتاب مقرر الكمبيوتز وتكنولوجيا

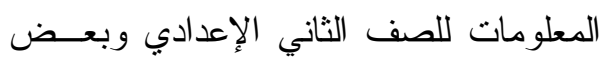

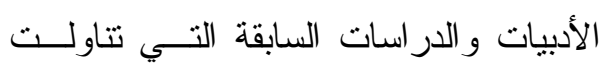

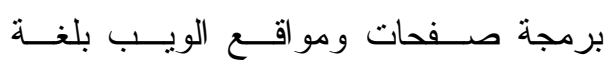
HTML وقد اتبع الباحث عدد من معسايير

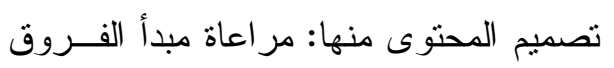

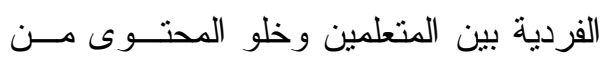

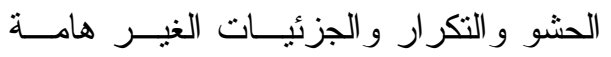
و التكامل بين المعرفـــة الحاليــة، و الــــابقة

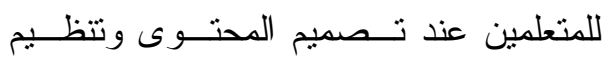

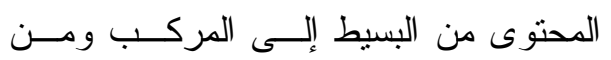

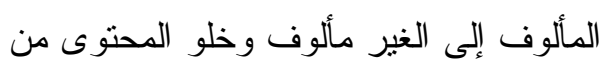

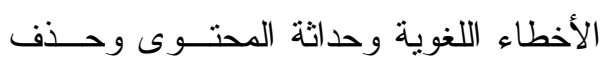

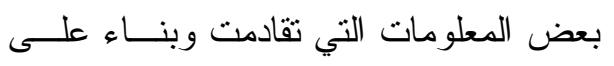




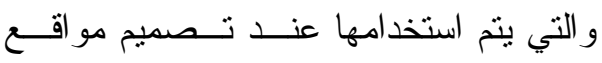

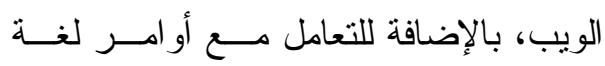

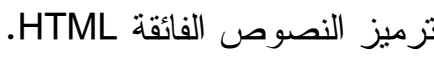

ـ ـ تصميم استر اتيجيات التعليم والتعلم:

تمنلات الاستر اتيجية التعليمية في هـــا

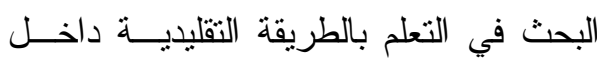

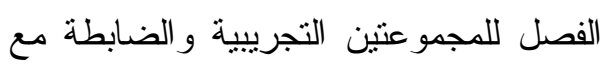
الاعتماد على محفز ات الألعاب الرقمية فـي ولئي

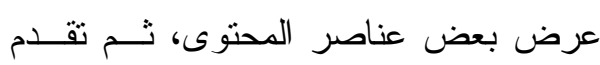

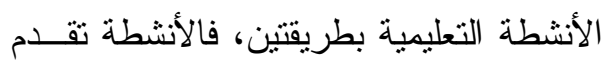

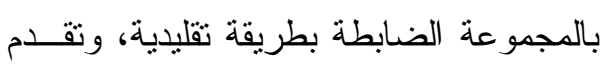
الأنشطة عن طريق محفز ات الألعاب الرقمية من خلال برنامج كاهوت Kahoot و الـــي مني

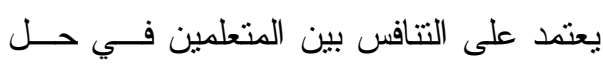
الأنشطة النعليمية.

\section{هـ تصميم الأشطة التعليميــة ووســائطها}

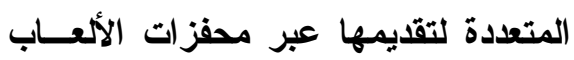

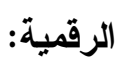

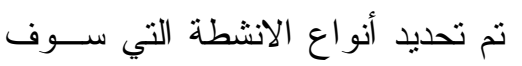

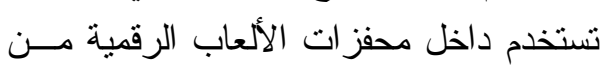

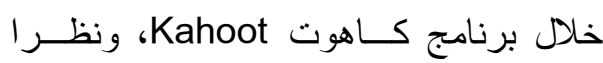
لطبيعة تطبيقات محفز ات الألعاب الرقمية فقد راعى الباحث عدد مــن معسايير تــميم الأنشطة التعليمية، ووسائطها لتقديمها عبـــر

$$
\begin{aligned}
& \text { محفز ات الألعاب الرقمية، وهي: } \\
& \text { أ. معايير خاصة بالنصوص: }
\end{aligned}
$$

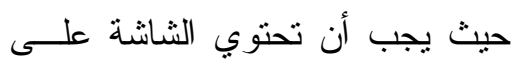
أقل عدد من الكلمات، و التقليل من اســتخدام

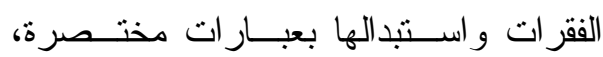

فيما بينهم، ولكي يــنقن التلميــذ المعسارف

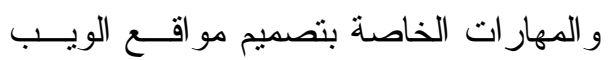

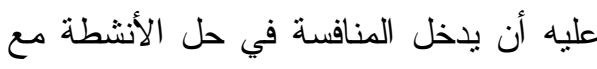

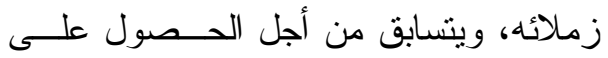
أكبر عدد من النقاط ويسبق في الترنيب. r. تصميم الأنشطة ومهام التعلم:

تم تصميم مجموعــة مــن الأنسشطة

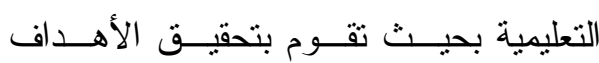
التعليمية، وقد راعى الباحث عدة معايير عند

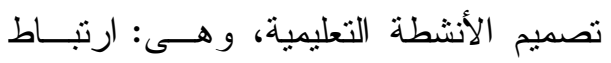

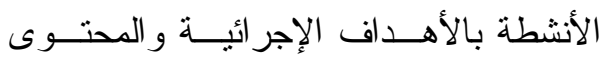

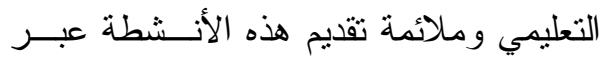

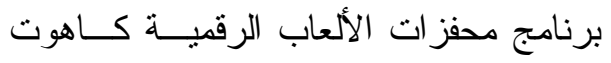

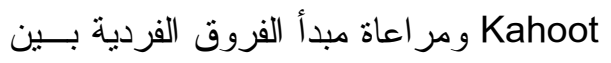
المتعلمين واستتارة دافعية المتعلمين وتحقيق

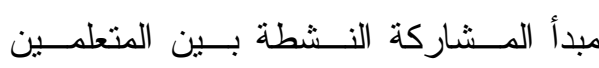

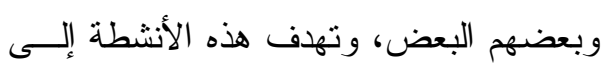

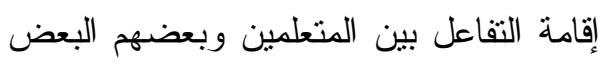

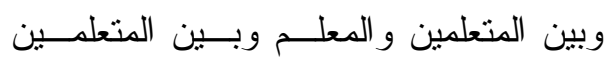

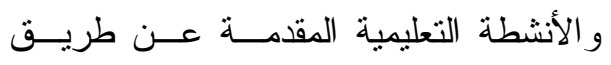

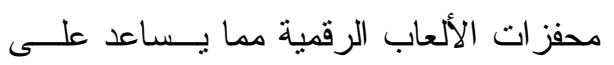
التأكد من تحقيق الأهداف المطلوبة. وقد نم بناء الأنـشطة فـــي برنــامج

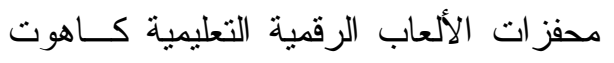
Kahoot علـى مجموعــة مــن الأنسشطة

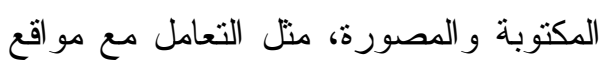

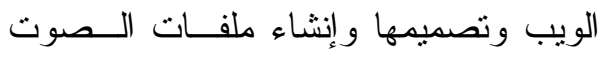

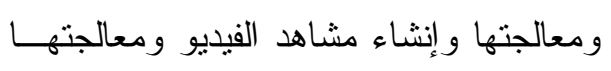


و الرسومات و الرموز و الارنباطات وغيرهــــا من الأدوات التي تمكن التلميذ من التفاعـل ولتصل

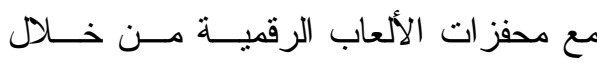

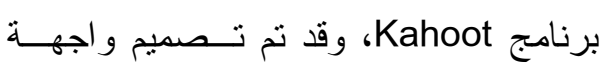

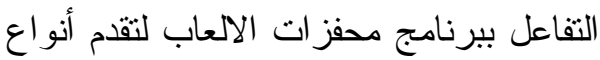

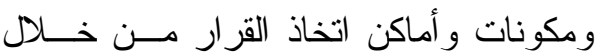

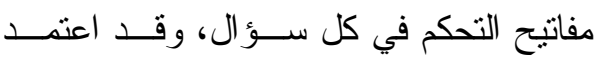
الباحث على الأسئلة النصية، و المصورة التي

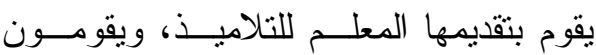
تز امنيا بحل الأسئلة و التتافس فيما بينهم، كما لئل

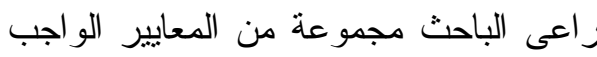

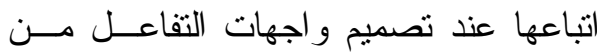
حيث الاتزان و البساطة و التصميم المنطقـي وني لعناصر الثانثة، وقد نم تحديد أنماط التفاعل عبر البيئة الإككترونية. فقي البداية قام الباحث بعمل حسساب على برنامج Kahoot بالدخول على الـــر ابط لبط التالي: http://www.create.kahoot.it، ويحدد الهدف من الحساب، ثم آلية الدخول
و الجمع بين الـــــ و الــصورة فـــي نفسـس الصفحة، واستخدام أنواع الخطوط المألوفة، ولئ

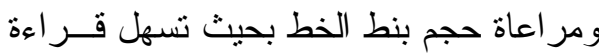

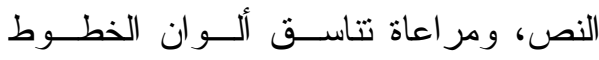
ومناسبتها للون الخلفية. ب. معايير خاصة بالفيديو:

تم ملائمة حجم نافذة الفيديو لأجهـزة التعلم النقال و السعة التخزينية لها، اســتخدام السرعة الطبيعية لعرض لقطــات الفيــديو،

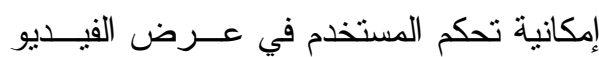
أكثر من مرة، بالإضافة لعدم زيــادة زمسـن فئن الفيديو الو احد عن من دقائق. ج. معايير خاصة بالصور:

تم استخدام الـصور بحيـث تكــــن بسيطة قدر الإمكان، مع ضرورة أن يكــون الهدف من الصورة و اضحا لدى المتعلم. I. تصميم واجهات التفاعـلـل والتفــاعلات البينية: - البعيم

تمثل واجهات التفاعل ما ير اه التلميذ

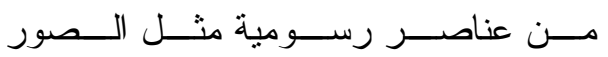
Kahoot!

Aready got an account? Log in

I want to use Kahoot!

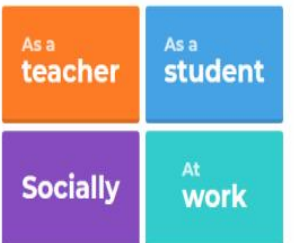

شكل (r) الهـف من إنشاء الحساب 
وبعد ذلك تم استكمال بيانات إنشاء حساب، وذلك على النحو التالي:

kahoot!

Arready yor a a account? Login

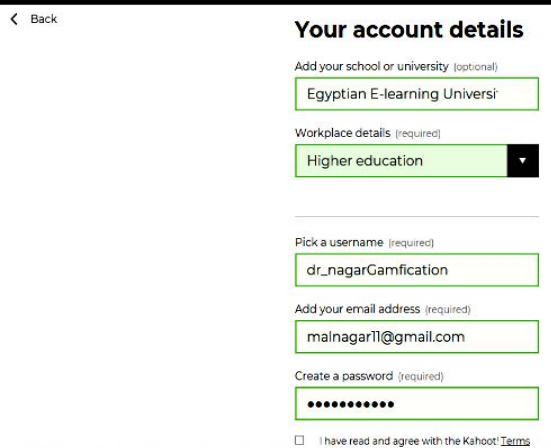

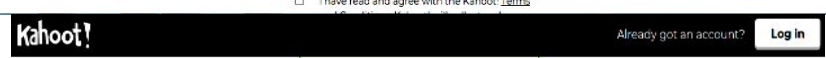

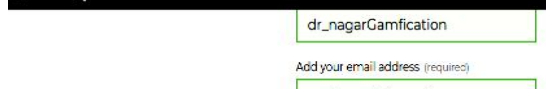

malnagarll@igmail.com

Create a a assemord |required|

anconon.cose.

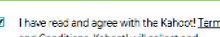

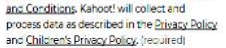

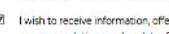

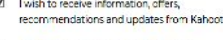

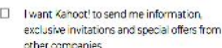

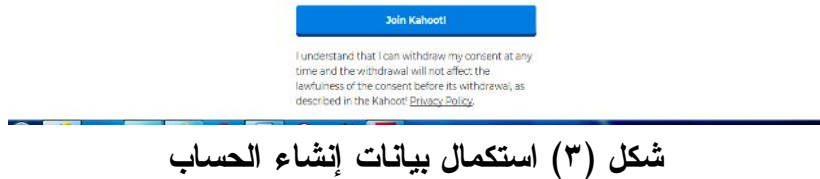

وبعد ذلك تم عمل صفحة باسم المستخدم، وذلك على النحو التالي:

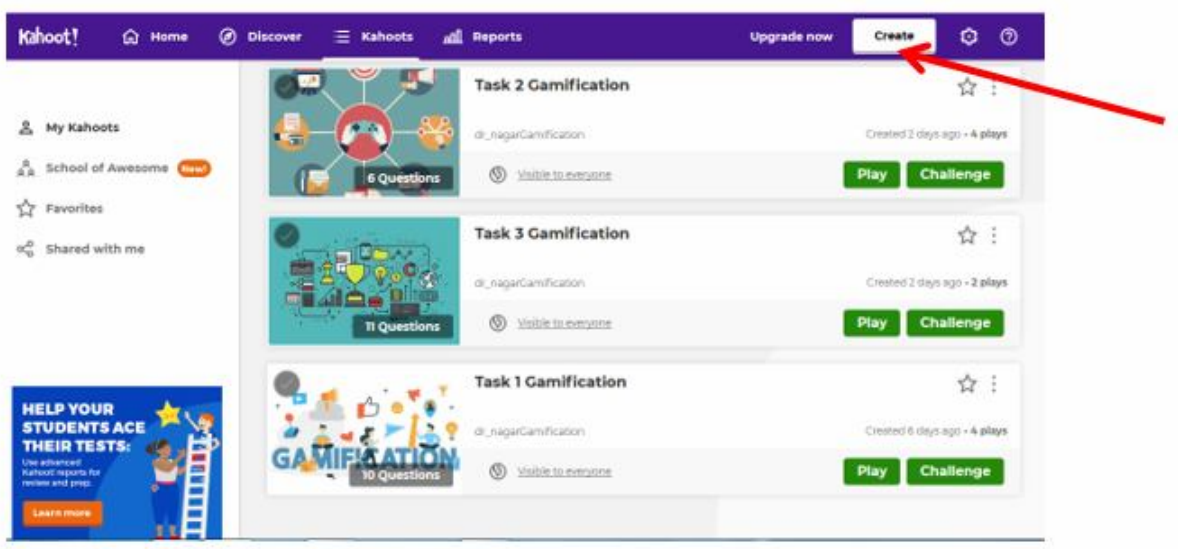

شكل (؛) إنشاء الحساب 


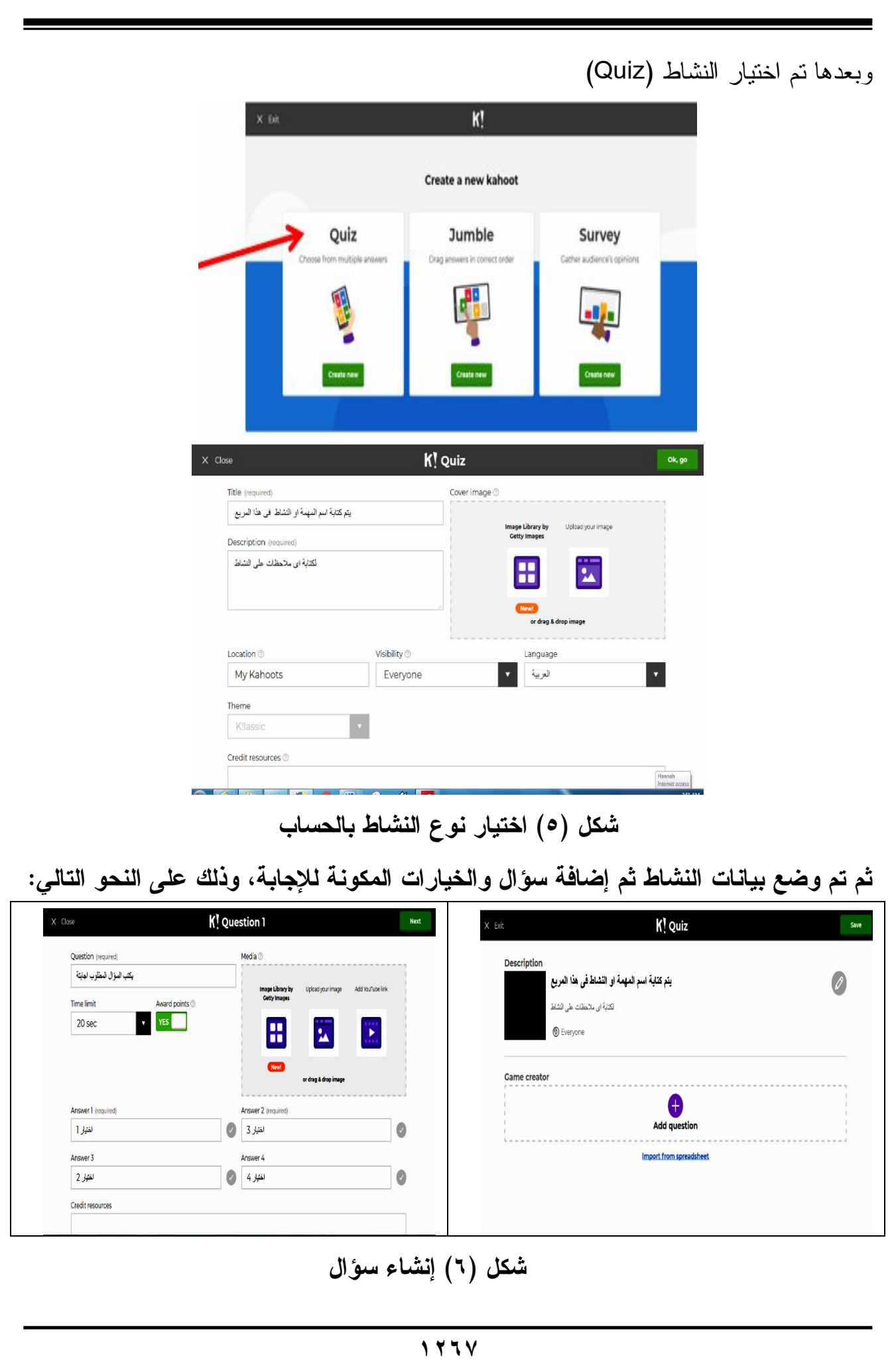




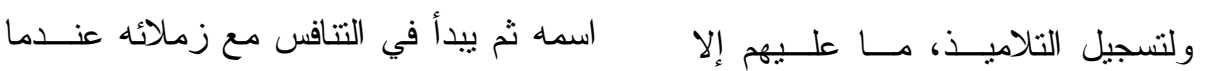

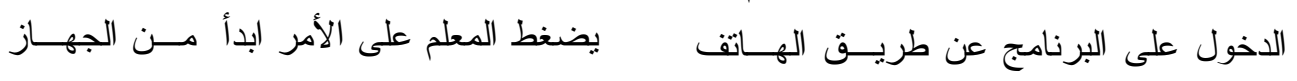

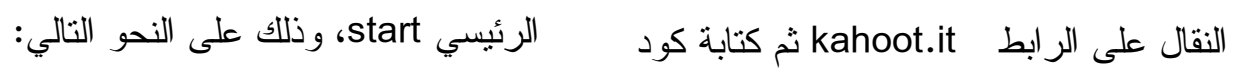

$$
\begin{aligned}
& \text { النشاط الذي ارسله المعلم، وبعد ذلك يسـسل لرجل }
\end{aligned}
$$

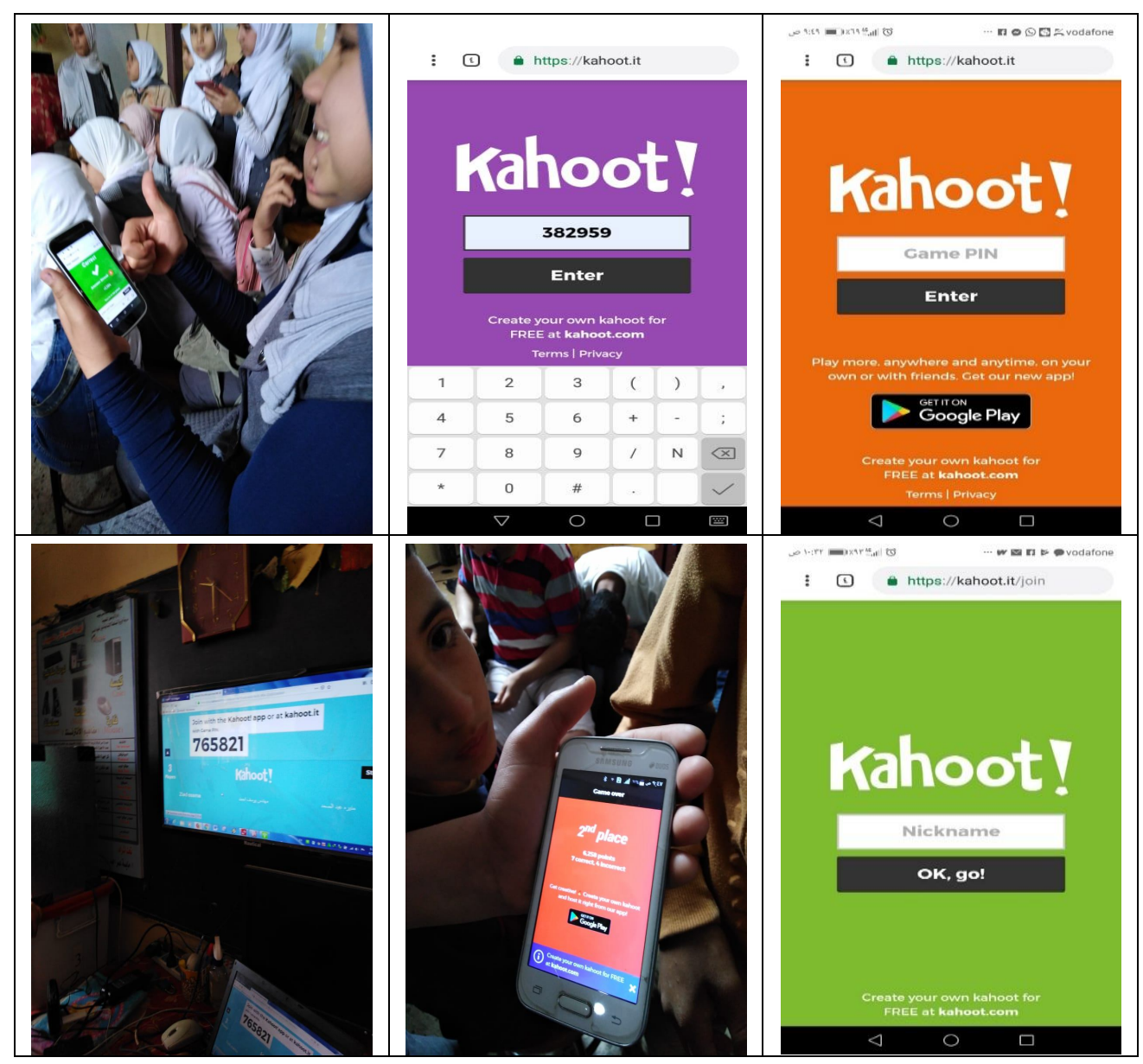

شكل (V) شاشات دخول التلاميذ للنشاط 


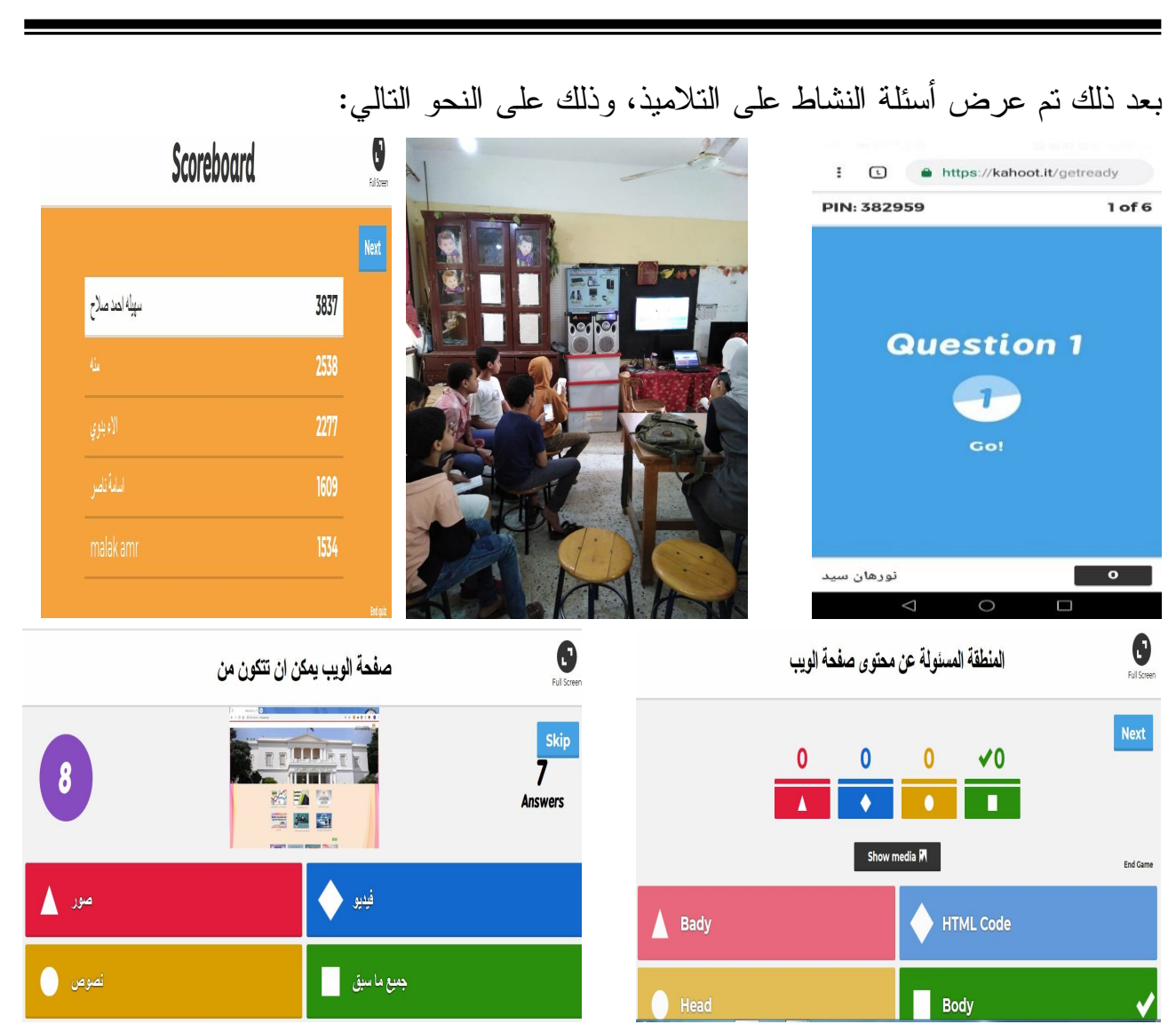

\section{شكل (^) أسئلة النشاط}

وتظهر أنماط الاستجابة على النشاط، وذلك على النحو التالي:
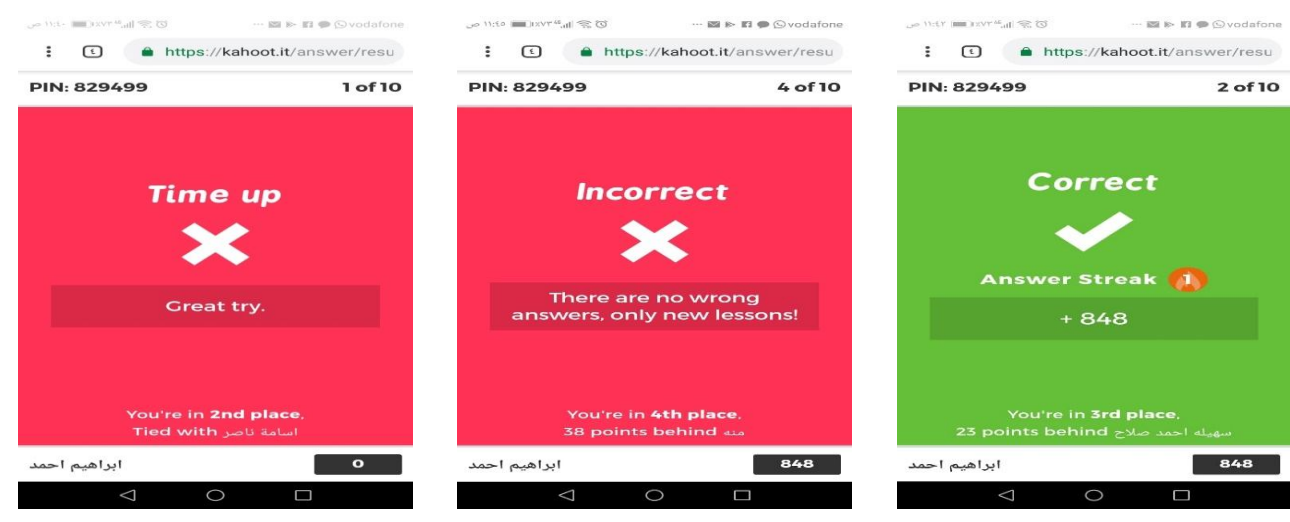


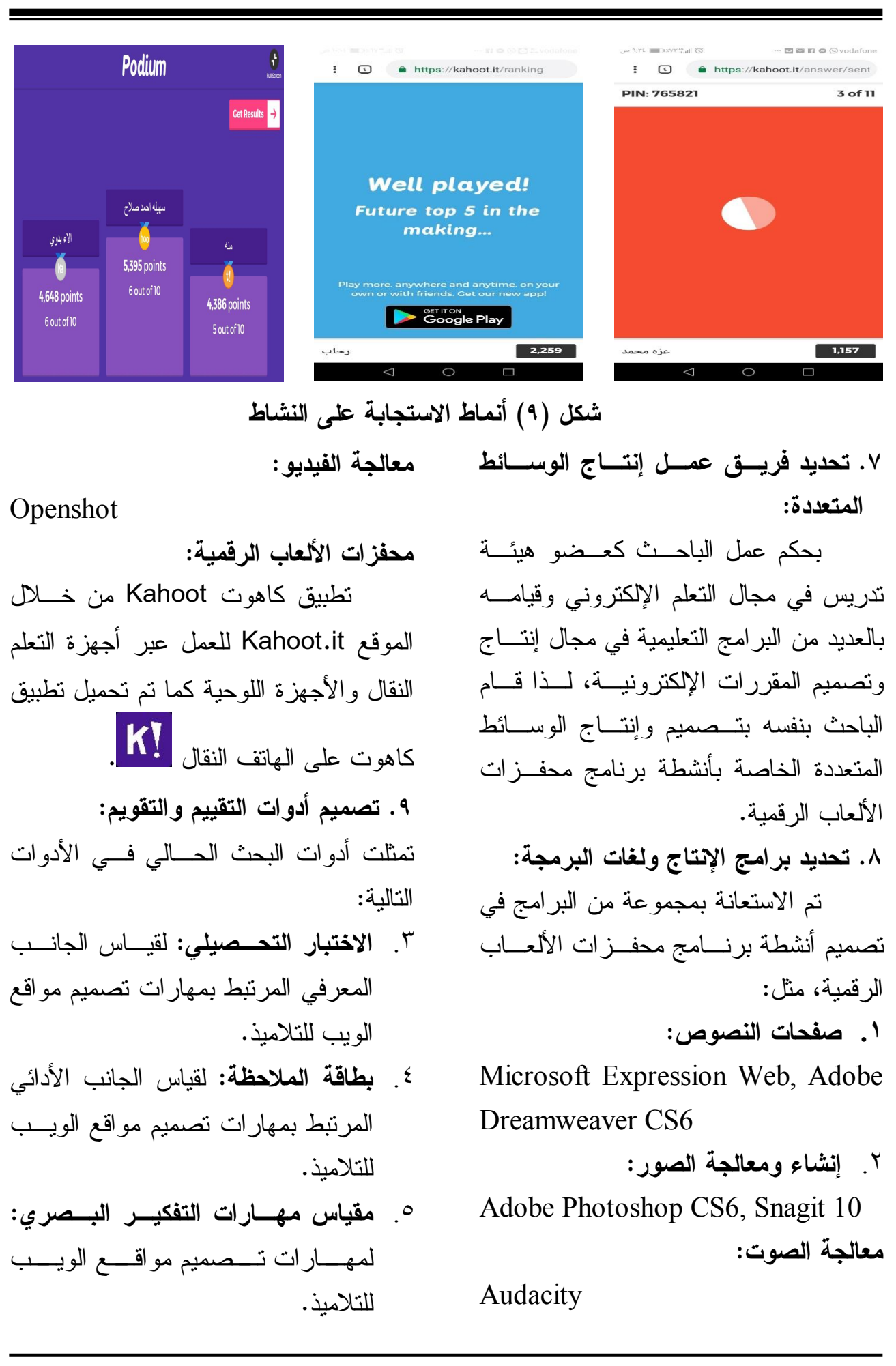


روعي في التصميم البساطة وعدم ازدحسام

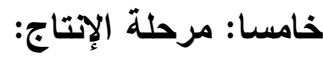

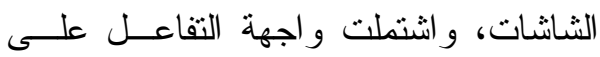
تشتمل هذه المرحلة على الخطــــوات الإلـات

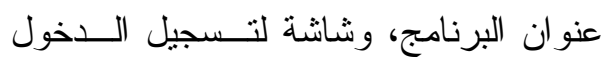

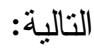
و الأنشطة التفاعلية؛ و التي ينم البدء فيها من ونت لنئ خلال المعلم مع وجود التلاميذ بالتز امن على لبه لبه أجهزتنهم. سادسا: مرحلة التقويم:

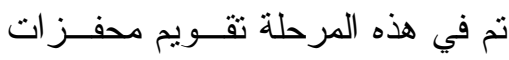
الألعاب الرقمية وذلك عن طريق ملاحظـــة

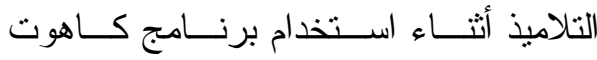
Kahoot

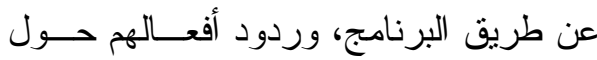
نتيجة التتافس بين التلاميذ، هذا بالإضافة إلى ولى

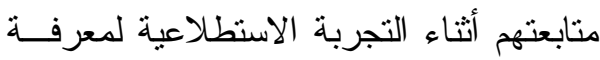

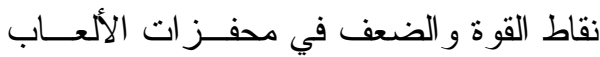
الرقمية للوصـــول بهمــــا للــشكل النهـــئي للنطبيق، وتتضمن هذه المرحلة ثلاث مهام،

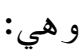
ا. اختبار محفزات الألعاب الرقمية: وتم ذلك عن طريق تطبيق محفــزات ات مات الألعاب الرقمية على عينة استطلاعية وذلك لتقييم أثز استخدام محفز ات الألعاب الرقميــة الرقية المقترحة، وتحديد الصعوبات التي قد تو اجه

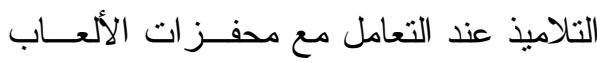
الرقمية، ولمعرفة آر اء التلاميذ فــي الــتعلم عبر محفز ات الألعاب الرقمية.

ا ـ إنتـــاج الوســـائط المتعــدة الخاصـــة بمحفز ات الألعاب الرقمية:

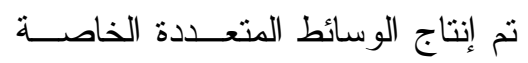
بمحفز ات الألعاب الرقمية من خــلادل إنتـــاج النصوص و الصور و الفيديو وملفات الصوت

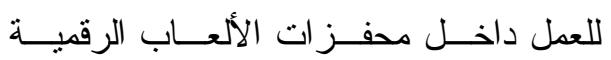
باستخدام برنامج كاهوت Kahoot، كما تــ

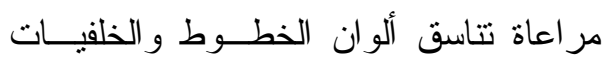
و أحجام الخطوط و الصور ، وعــدم ازدحسـام الثاشات، ووضوح الصور • r. إنتاج المحتوى والأنشطة التعليمية: قام الباحث بإنتــاج مجموعـــة مــن الأنشطة التعليمية، و الخاصة بمهار ات تصميم

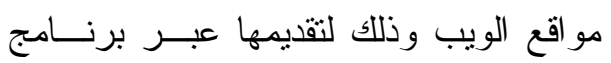
محفزات الألعاب الرقمية كــاهوت Kahoot

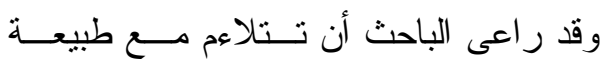

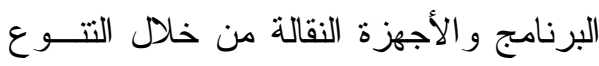

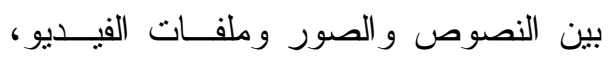
وكذلك تحديد الأنشطة النعليمية فـي ضـــو ولهو الأهداف التعليمية. r. إنتاج واجهات التفاعـل والتفــاعلات البينية: عند بناء صفحات محفز ات الألعـاب الرقمية من خلال برنامج كــاهوت Kahoot 
وبعد النطبيق القبلي لأدوات البحث يتم شرح

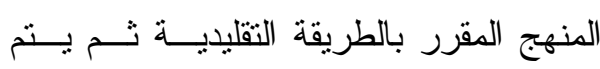
تطبيق الأنشطة التعليمية على الهجمــوعتين احدهما بالطريقة التقليدية و الأخرى من خلال

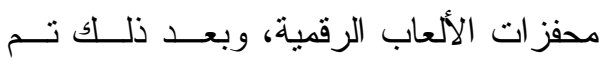
التطبيق البعدي لأدو ات البحث.

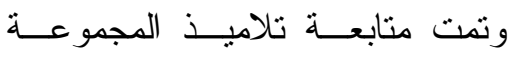

التجريبية من خلال التقارير التي تصدر عن تاند برنامج كاهوت Kahoot، ثم رصد أنشطتهم

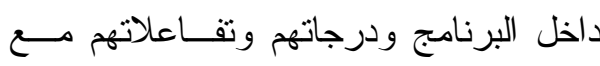

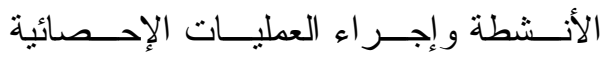

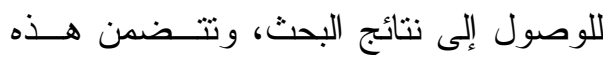

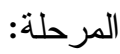

ا. الاستخدام النهائي لبرنـــامج محفــزات الألعاب الرقمية Kahoot ونم فيها اتخاذ القرار باستخدام برنامج محفز ات الألعاب الرقمية Kahoot إذا ثبـــــ

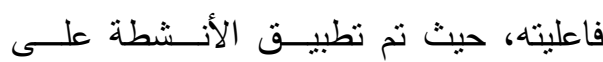
المجموعة التجريبية للبحث. ץ. النشر والإتاحة: وتم فيها إتاحـــة محفــز ات الألعــاب الرقمية للاستخدام الفعلي عن طريق نـشـرها

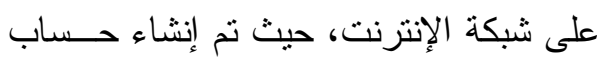

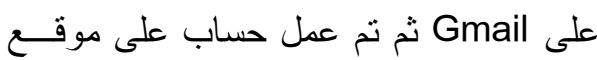

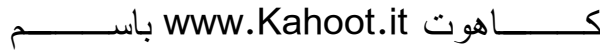

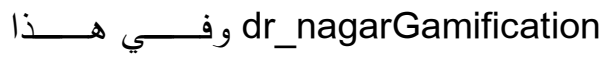
الحساب نم اعداد وتصميم جميــع الأنـشطة r ب . رصد نتائج الاستخدام:

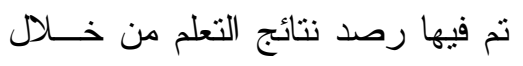

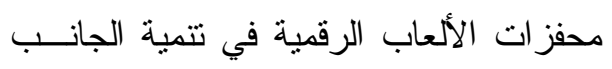

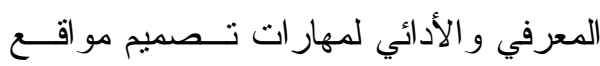

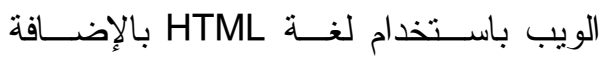
لمهارات التفكير البصري لدى تلاميذ الحلقة الإعدادية. r. إجراء التعديلات النهائية: تم فيها إجـــر اء التعــديلات النهائيــة لتتمتع محفز ات الألعاب الرقمية بالصلاحية. سابعا: مرحلة التطبيق: وفي هذه المرحلة نم تقسيم التلاميــذ هرئ الــى مجمــو عتين عـشـو ائيتين بالتــساوي، احداهما تجريبية و الأخرى ضابطة، كما تـــ

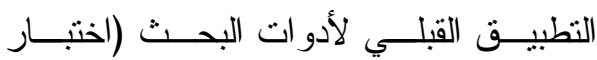
تحصيلي - بطاقة ملاحظة - مقياس مهار ات لادوب لهن التقكير البصري)، و عقب ذللك تــم تعلـــيمهر

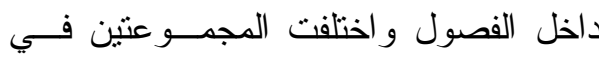
تطبيق الأنشطة، حيث اعتمدت المجموعــة الضابطة على أنشطة التعلم المقدمة بالطريقة

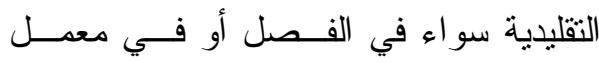
الكمبيوتز ، بينما اعتمدت المجموعة التجريبية على محفزات الألعاب الرقمية فــي تطبيــن أنشطة التعلم من خـــلال برنــامج كــاهوت

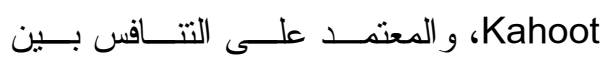

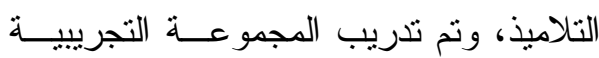
على التعامل مع البرنامج و أنشطته التعليمية، 


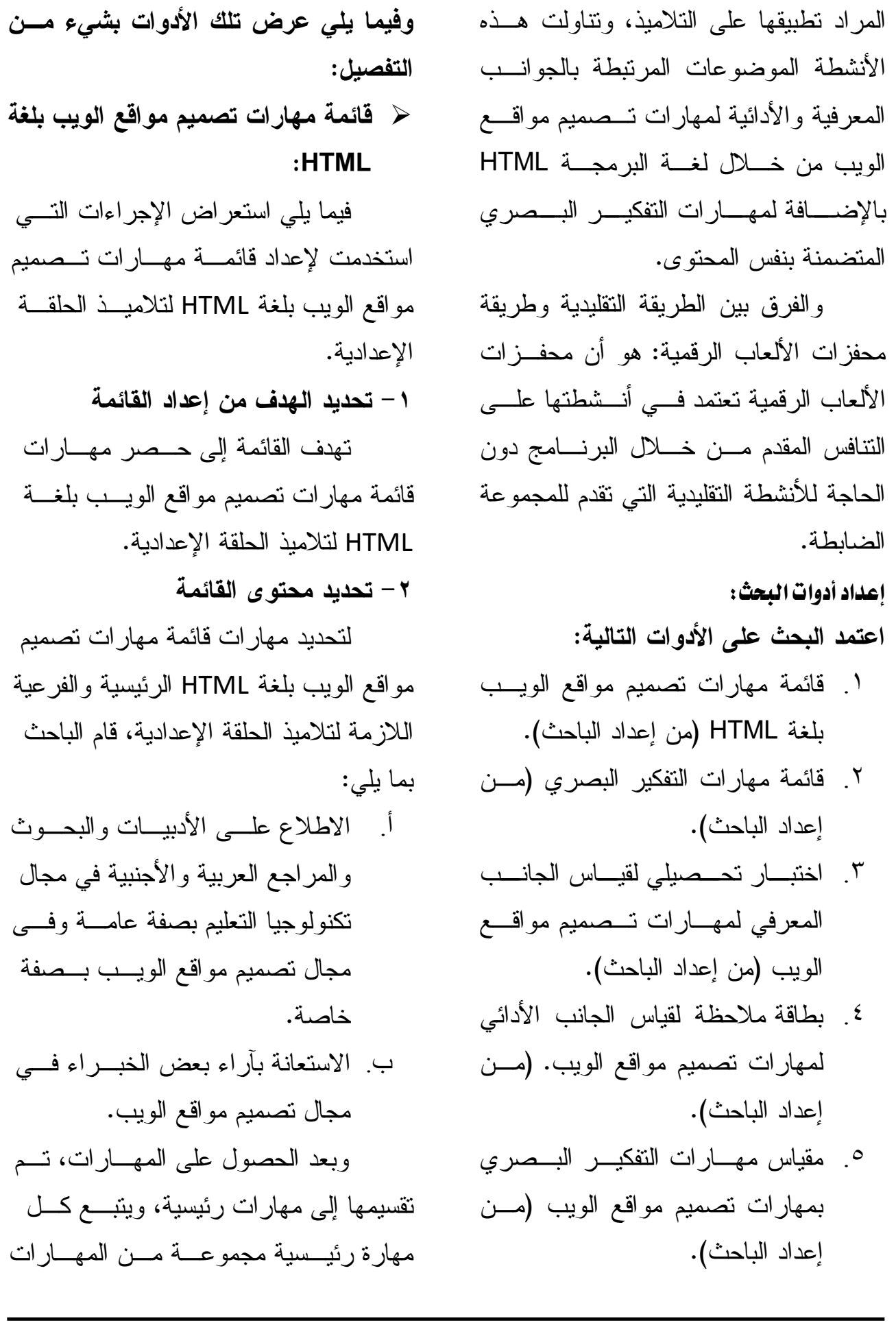




\section{r - تحديد محتوى القائمة}

لتحديد مهـــار ات التفكيــر البــصري

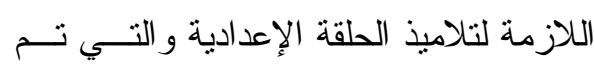

تضمينها في القائمة، قام الباحث بما يلي:

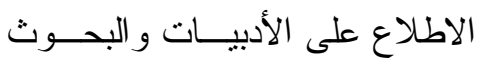

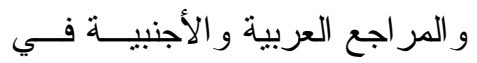

مجال علم النفس بصفة عامة وفـى لئى

مجال مهــار ات التفكيــر و التفكيــر

البصري بصفة خاصة.

(ب) الاستعانة بآر اء بعض المتخصصين

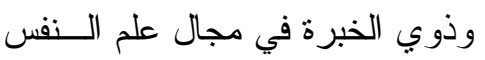

ومهار ات التفكير و التقكير البصري.

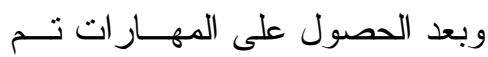

تقسيمها إلى ست مهار ات رئيسـة، ورهـئ

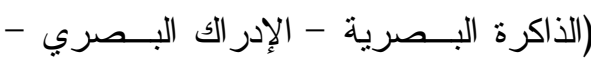

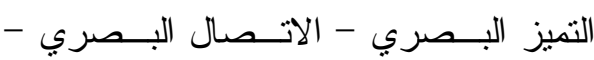

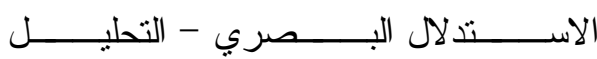

(البصري). - (الاسم)

\section{r- التحقق من صدق القائمة}

نم عرض القائمة في صورتها الأولية

على مجموعة من الخبر اءو المتخصصين في مجالات علـــم الــنفس ومهــار ات التفكيــر و التفكير البصري، وطُب منهم إبداء الــر أي في بنود القائمة من حيث: مناسبة المهــار ات لمستوى التناميذ، ومناسبة المهار ات الفرعية

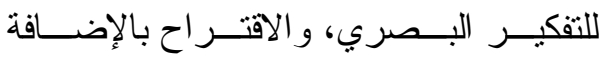

$$
\text { و الحذف وفق ما يرونه مناسبا }
$$

الفرعية المتعلقة بها، وقد تمــت مر اعــاة أن تصـاغ جميع المهار ات بطريقـــة إجر ائيـــة،

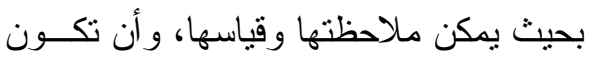
و اضحة لغويا وغير مركبة. r- التحقق من صدق القائمة نم عرض القائمة في صورنها الأولية

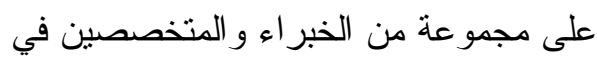

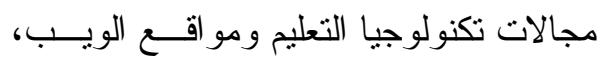

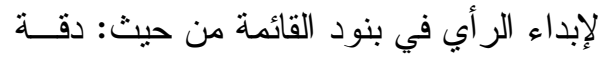
الصياغة، و انتماء المهارة الفرعية للمهــارة

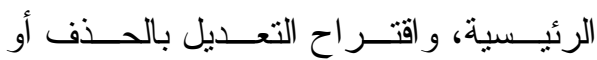
الإضافة. وقد اقترح الخبر اء بعض التعـديلات منها حذف بعض المهار ات المكررة، وتقسيم

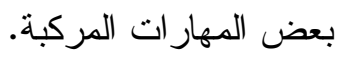
وبعد إجر اء التعديلات بناء على آر اء

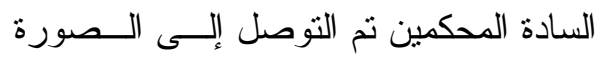
النهائية، حيث بلغ عدد المهار ات الرئيـسية

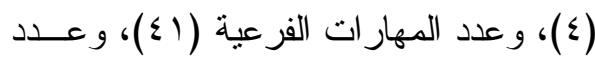

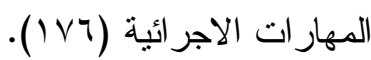
قائمة مهار ات التفكير البصري لاتهري

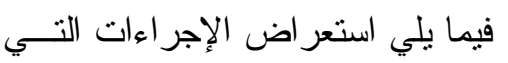

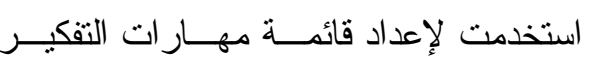
البصري لتلاميذ الحلقة الإعدادية 1 - تحديد الهـف من إعداد القائمة

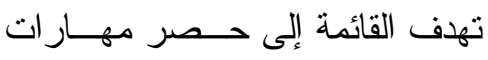

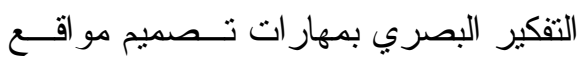
الويب لتلاميذ الحلقة الإعدادية. 
هدف الاختبــار التحــصيلي لقيــاس

الجانب المعرفي لدى تلامبذ الحلقة الإعدادية

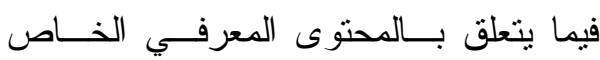
بمهار ات تصميم مواقع الويب بلغة HTML. ץ. . جدول مواصفات الاختبار: تم إعداد جدول مواصفات الاختبـــار بحيث يوضتح الموضوعات التــي يغطيهـا الاختبار • وقد تمنلت هذه الموضوعات فــي تصميم مواقع الويب باستخدام لغة HTML،

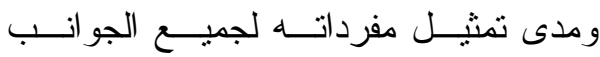
المعرفية، ومدى توزيع هذه المفردات علــى مـسـتويات الأهــــداف المعرفيـــة الخاصــــة

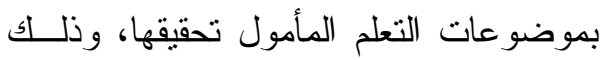
كما هو موضتح بالجدول التالي:
وقد أقر السادة المحكمون بانتماء ثللك

المهـــار ات لمهـــار ات التفكيــر البــصري، ومناسبتها لتلاميذ الحلقة الإعدادية. ع - حساب ثبات القائمة

قام الباحث بحساب ثبات القائمة عـنـ

طريق استخدام معادلة معامل الاتفاق، وذلك بحساب عدد مرات الاتفاق مقسوما على عدد

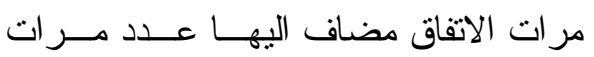
الاختلاف، وقد بلغ معامــل الاتفــاق بــين

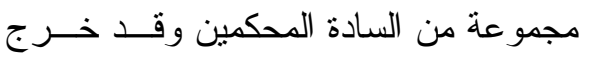

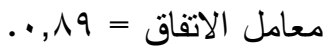
الاختبار التحصيلي: تم تصميم الاختبار التحــصبلي فـي ضو ء مجمو عة الخطوات التالية: ا. تحديد الهوف من الاختبار:

جدول (Y) جدول مواصفاث الاختبار التحصيلي

\begin{tabular}{|c|c|c|c|c|c|c|c|c|}
\hline \multirow{2}{*}{ المئوية } & \multirow[t]{2}{*}{ 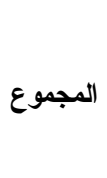 } & \multirow[b]{2}{*}{ 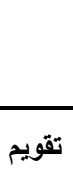 } & \multirow[b]{2}{*}{ تركيب } & \multirow[b]{2}{*}{ تحليل } & \multicolumn{3}{|c|}{ مستويات الأهداف } & \multirow[t]{2}{*}{ الموضوعات } \\
\hline & & & & & تطبيق & فهم & تذكر & \\
\hline$\% \backslash \vee, 90$ & $\checkmark$ & 1 & 1 & 1 & 1 & r & 1 & التعرف على أساسيات مواقع الويب. \\
\hline$\% \curlyvee \wedge, r)$ & 11 & 1 & 1 & $\varepsilon$ & 1 & r & 1 & تصميم و إنشاء مواقع الويب. \\
\hline$\% 10, \uparrow \wedge$ & 7 & 1 & . & 1 & 1 & r & 1 & إنثاء ومعالجة ملفات الصوت لمواقع الويب. \\
\hline$\% r_{0}$, T & 1. & 1 & . & 1 & r & ○ & . & إنشاء ومعالجة ملفات الفيديو لمواقع الويب. \\
\hline$\%$ \% r,Ar & 。 & . & . & 1 & r & r & . & مهار ات تصميم مواقع باستخد ام لغة HTML. \\
\hline$\% 1 \ldots$ & rq & $\varepsilon$ & r & $\wedge$ & $\wedge$ & $1 \varepsilon$ & r & المجموع \\
\hline
\end{tabular}




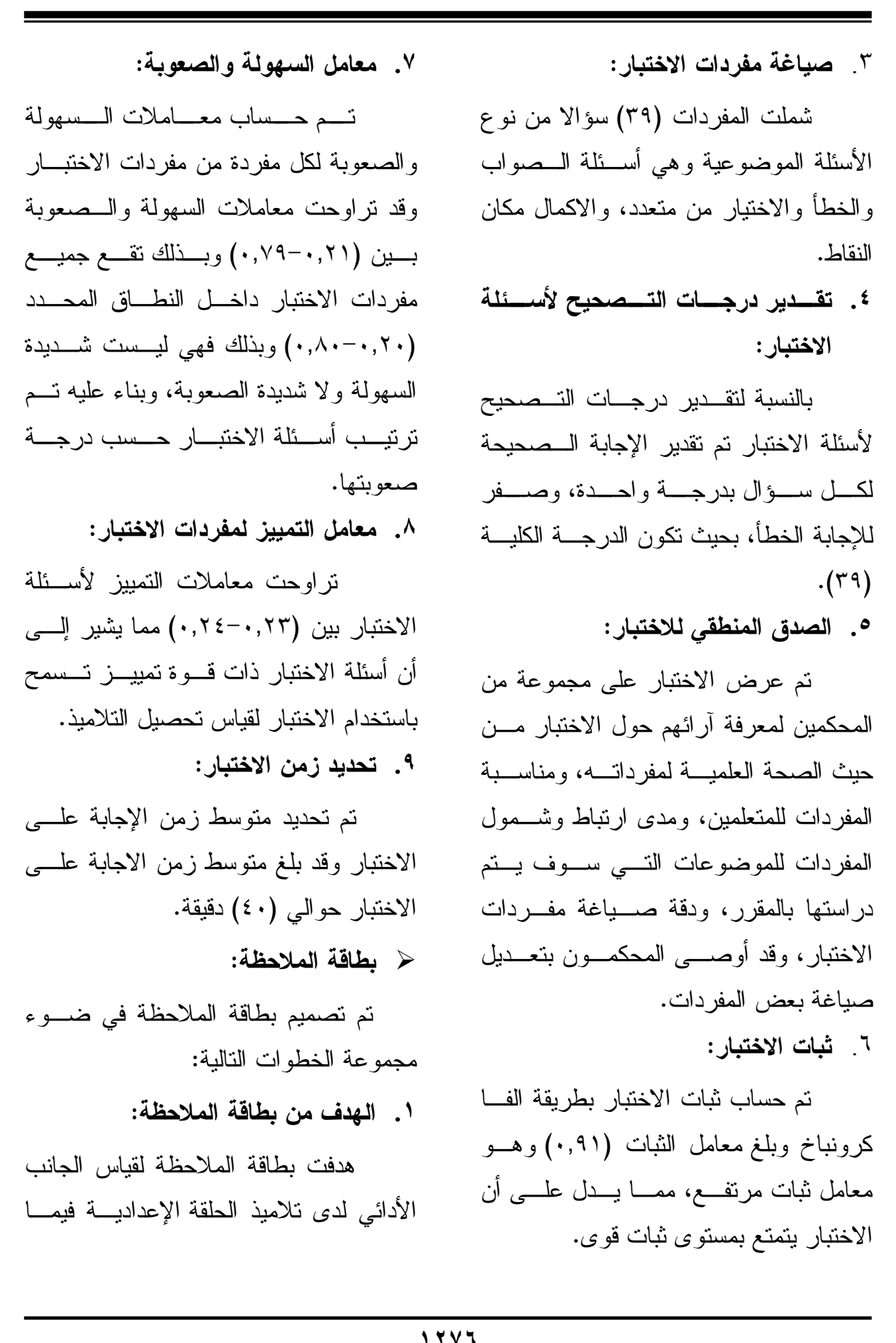


بالأهداف وصلاحيتها للتطبيق وفـى ضـــــ أره آراء المحكمين أصبحت البطاقة في شـــالها النهائي بعد تصحيح الصباغة اللغوية. ๑. ثبات بطاقة الملاحظة:

تم حساب معامــل الثبـــات لبطاقـــة الملاحظة باستخدام برنــامج SPSS لكــل

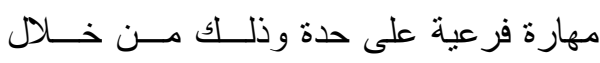

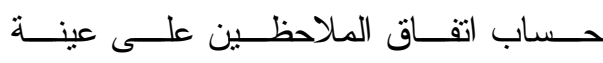

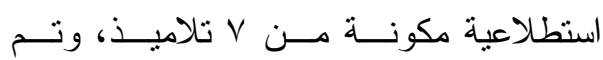
ملاحظتهم من قبل اثثين مـنـ الملاحظــين،

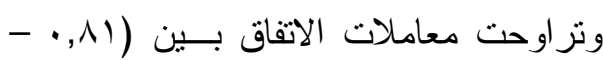

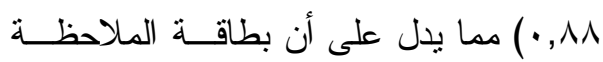
تتمتع بدرجة ثبات عالية. 7. الاتساق الداخلي لبطاقة الملاحظة: تم حساب معاملات الارتبــاط بــين المهار ات الفرعية وجميعها دالة عند مستوى أقل من (0., •))، مما يدل على وجود اتساق

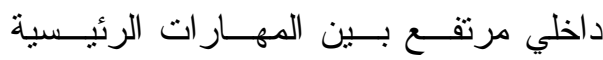

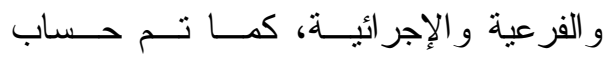

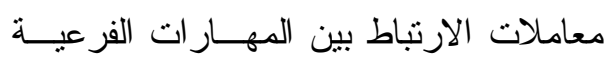
و إجمالي البطاقة وجميعها دالة عند مـستوى الارثاط لهن (0.0., ) مما يدل على وجود اتساق داخلـي مرتفع لبطاقة الملاحظة. > مقياس مهـــارات التفكيــر البـصري لمهار ات تصميم مواقع الويب: وقد تم تصميم المقياس وفق ما يلي:
يتعلق بالجانب الأدائي الخــاص بمهــارات تصميم مو اقع الويب بلغة HTML.

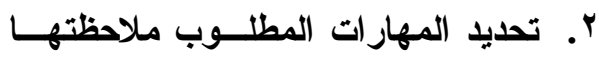
إجر ائيا:

قام الباحث بإعداد بطاقة الملاحظة في

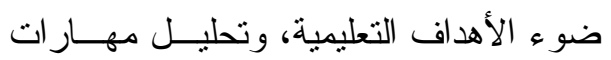
تصميم مو اقع الويب بلغة HTML المحسـددة

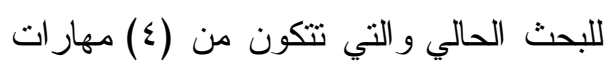

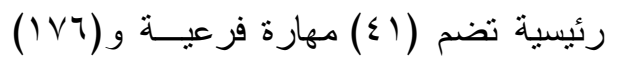

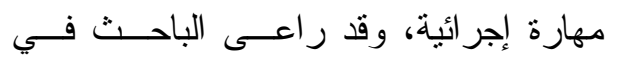

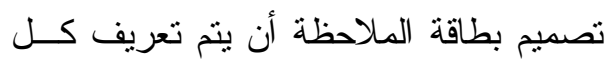

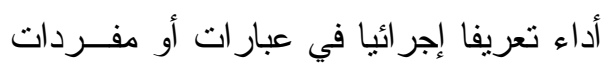

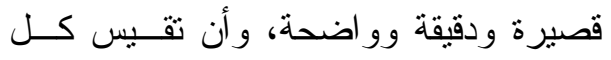
مفردة سلوكا محددا بوضوح. r. نظام تسجيل الأداء ببطاقة الملاحظة: تم الحكم على أداء التلميذ عن طريق

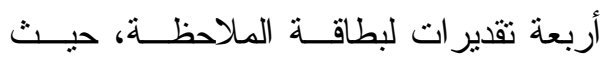

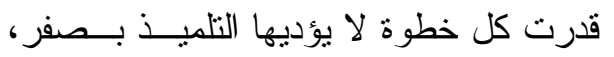
ودرجة واحدة (أدى بدرجة ضعيفة)، درجتان (أدى بدرجة متوسطة)، ثناث درجات (أدى لندان بدرجة جيدة). ؛. . صدق بطاقة الملاحظة: تم عرض البطاقة على مجموعة مـن

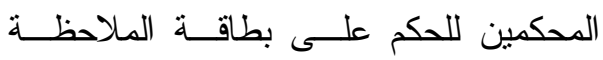
ومر اجعة مفرداتها و التأكد من الدقة العلميـــة ومناسبة الأسئلة لغويا و علميا ومدى ارنباطها 
التلميذ بالإجابة على كل سؤ ال وذلك باختيار

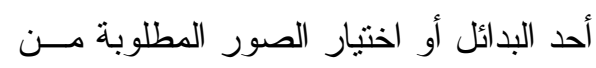

$$
\text { جدول الصور • - ج }
$$

". تحديد محــاور (المقــاييس الفرعيــة) مقياس مهارات التفكير البصري

في ضو و قائمـــة مهــــار ات التقكيــر

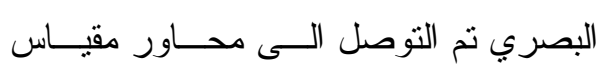

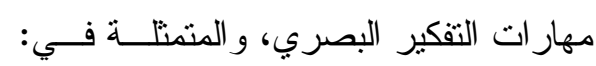

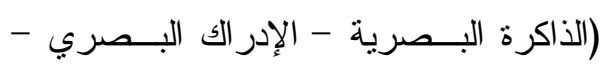

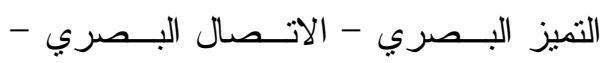

الاستدلال البصري - التحليل البصري).

؛. . صياغة عبار ات المقياس

في ضوء المحاور السابقة تم صياغة

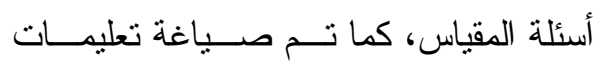

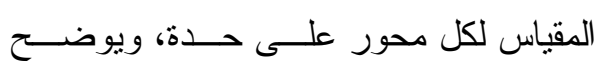

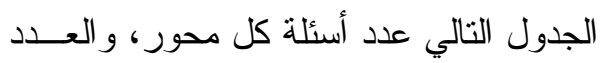

الكلي لأســـلة مقيــاس مهــار ات التقكيــر

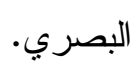

ا. ـ الهـف من مقياس مهــــارات التفكيـر

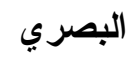

يهدف المقياس إلـى تعـرف مــدى

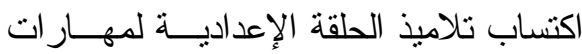

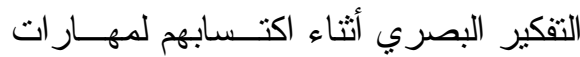

تصميم مو اقع الويب باستخدام لغة HTML،

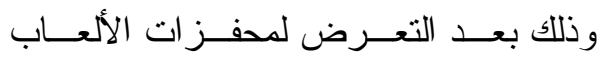

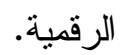

r. . طريقة بناء مقياس مهــارات التفكيـر

$$
\text { البصري }
$$

تم بنـــاء مقيــاس مهــار ات التفكيــر

البصري في شكل أسئلة مصورة تدور حول

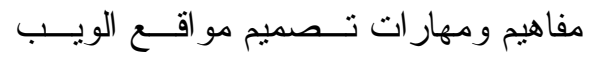

باستخدام لغــة HTML الموجــودة بكتـــاب

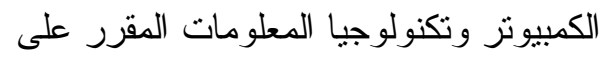

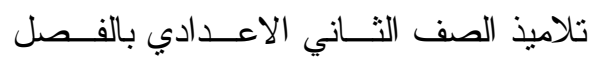

الدر اسي الأول، و المرتبطة بأبعاد بناء مقياس باس بادي

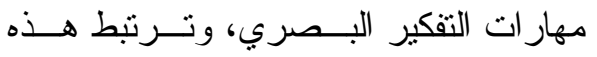

\begin{tabular}{|c|c|c|c|c|c|}
\hline عدد العبار ات & المحور & 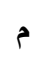 & عدد العبارات & المحور & م \\
\hline v & الاتصال البصري & $\varepsilon$ & r. & الذاكرة البصرية & 1 \\
\hline v & الاستدلال البصري & 0 & $\wedge$ & الإدر الك البصري & r \\
\hline 9 & التحليل البصري & 7 & v & التميز البصري & $r$ \\
\hline & & & 71 & الإجمالي & \\
\hline
\end{tabular}

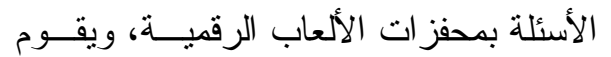

جدول (r) مواصفات مقياس مهارات التفكير البصري 


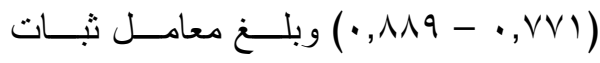

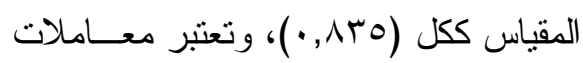
ثبات مقبولة ومناسبة، مما يدل على صلاحية المقياس للاستخدام. ^. عساب زمن المقياس

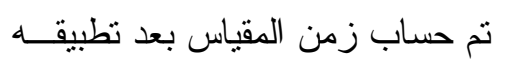

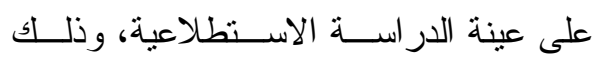
برصد الزمن الذي استغرقه كل تلميذ، وجمع

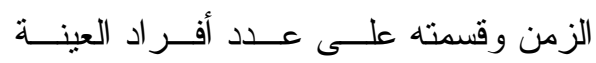

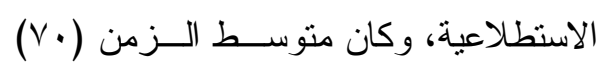
دقيقة.

\section{• اختيار مجموعتي البحث:}

حيث تم اختيار عينة البحث عـشو ائيا

وتقسيمهر عشو ائيا إلى مجمو عتين بالتساوي، علئ

$$
\text { وذلك على النحو التالي: }
$$

- المجموعة التجريبية:

وتكونت من (·r) تلميذا وتلميذة من

تلاميذ الصف الثاني الإعدادي تلقت الــتعلم

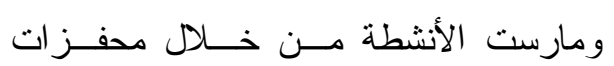
الألعاب الرقمية.

\section{- المجموعة الضابطة:}

وتكونت من (•r) تلميذا وتلميذة من

تلاميذ الصف الثاني الإعدادي تلقت الــتعلم

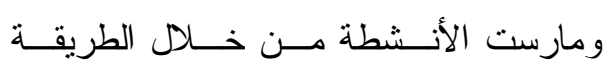

التقليدية.
•. حساب صدق المقياس

تم عرض الصورة الأولية للمقيــاس

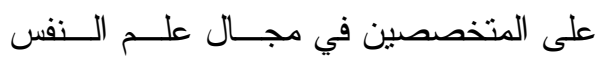

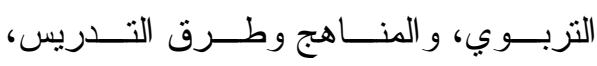
و تكنولوجيا التعليم، بهدف التحقق من صدق ولقري

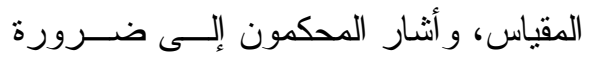
تعديل بعض الصور غير الواضحة، وتوحيد

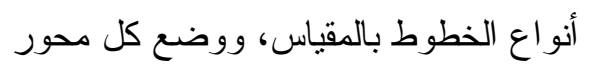

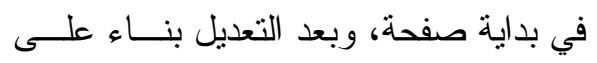
آر اء السادة المحكمين نم التوصل إلى مقياس

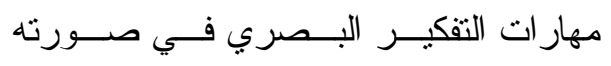
النهائية، حيث اشتمل علــى ســتـة محـــاور رئيسية بها ح1 سؤالاً.

7. وضع تعليمات المقياس

تم وضـــع تعليمـات لكـلـ محــور من محاور مقياس مهارات التفكير البصري

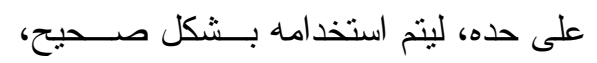

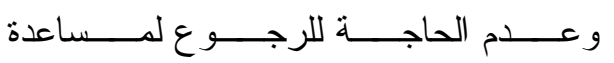
خارجية. V. حساب ثبات المقياس جل تم تطبيق مقياس مهـــار ات التفكيــر البصري استطلاعيا على عدد (10) تلميــذا

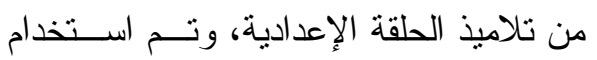
معامل ألفاكرونباخ لحساب ثبـــات محـــاور

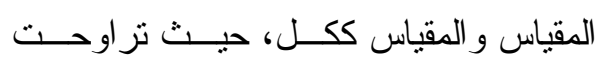

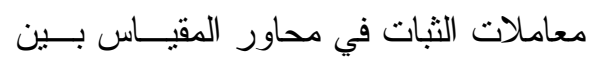




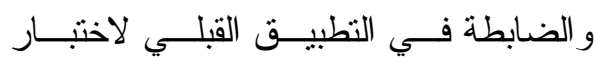

\section{• اختبار تكافؤ المجموعات:}

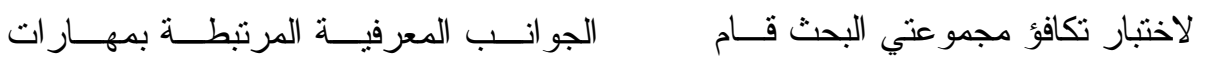

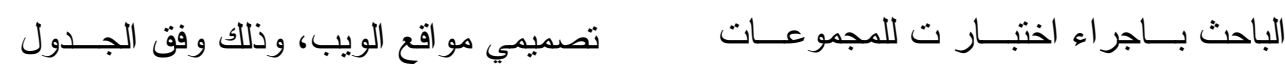

المستقلة Independent Sample t-test

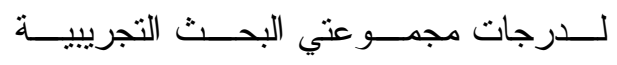

جدول (؛ ) الفروق بين متوسطات درجات المجموعتين التجريبية والضابطة في التطبيق القبلي

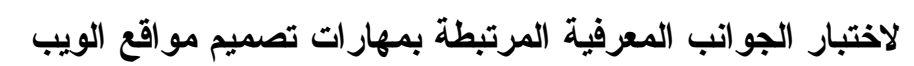

\begin{tabular}{|c|c|c|c|c|c|c|c|}
\hline الدلالة & مستوى الدلالة & قيمة ت & لدرجة & $\varepsilon$ & P & العظمى & المجموعة \\
\hline \multirow{2}{*}{ غير دالة } & \multirow{2}{*}{. } & \multirow{2}{*}{ r., } & \multirow{2}{*}{$0 \wedge$} & $1, r V$ & 11,97 & \multirow{2}{*}{ rq } & الضابطة \\
\hline & & & & rז,1 & Ir & & التجرييية \\
\hline
\end{tabular}

يتضح من الجدول السابق عدم وجود تصميم مو اقع الويب، وبالتالي هنالك تكــافؤ

فروق بين منوسطي درجـات المجمــوعتين بين مجموعتي البحث التجرييية و الضابطة.

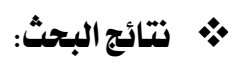

للتوصل الى نتائج البحث الحالي حول

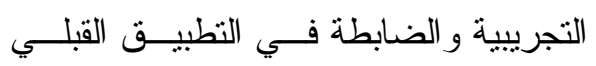
تحديد أثر استخدام محفزات الألعاب الرقمية

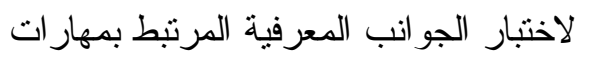

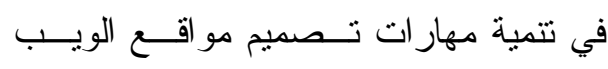

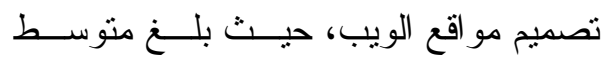
ومهارات التفكير البصري لدى تلاميذ الحلقة درجــات المجموعــة الــضابطة (1) 11 (1)

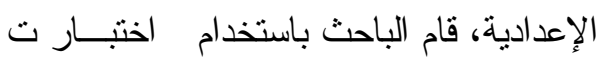

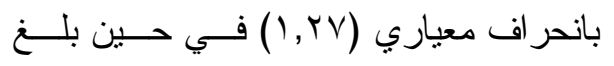
للمجموعات المرتبطة للمقارنة بين درجـات الإعات التيات

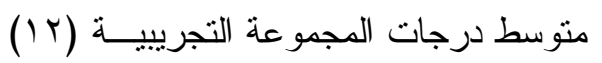
التلاميذ في التطبيقين القبلي و البعدي لأدوات

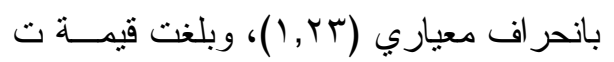

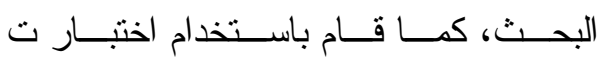

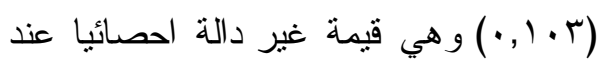

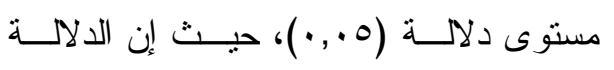
للمجموعات المستقلة للمقارنة بين التلاميذ في

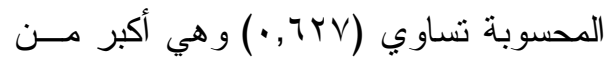
المجمو عتين التجريبية و الضابطة في التطبيق

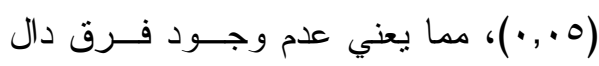
البعدي لأدوات البحث، كما نم استخدام مربع الحصائيا بين منوسطي درجات المجمـــو عتين

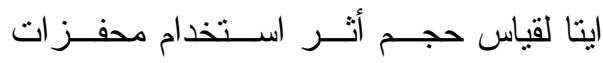

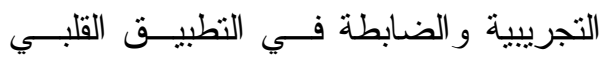
لاختبار الجو انب المعرفية المرتبطة بمهارات الألعاب الرقمية في تتمية مهـار ات تصديم 


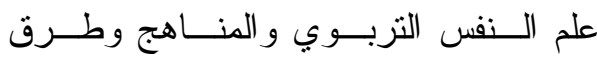
التدريس، وبعد إجر اء التعديلات نم التوصل ولن ولن

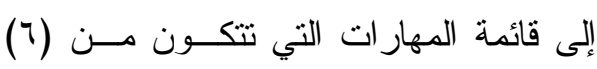
مهار ات رئيسية. للإجابة على السؤال الثالث للبحــث، و الذي نصه "ما التصور المقترح لمحفــزات الألعاب الرقمية في تتمية مهــار ات تــصميم مو اقع الويب، ومهارات التفكيـر البــصري

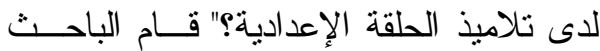
بالاطلاع على البحــوث و الدر اســات التــي لإني

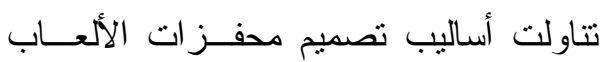
الرقمية، وقام ببنـــاء المحفــز ات باســــــام

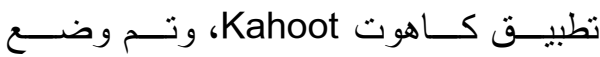
مجموعة من الأنشطة التعليمية التي يتتــافس

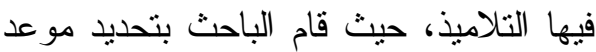

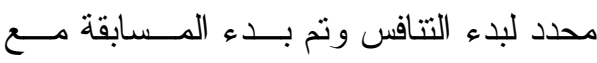
دخول التلاميذ في نفس الوقت و البدء في حل الأنشطة، وتظهر التحفيزات بعد كل ســـوال وعقب الانتهاء من النشاط، حيث يحدد الفائز

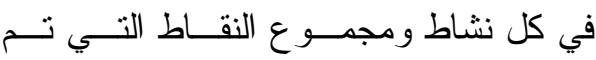
الحصول عليها، وتم تصميم البرنامج وفقــــا

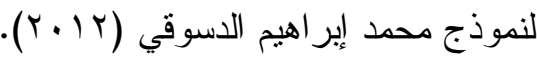
للإجابة على السؤال الرابع للبحــث،

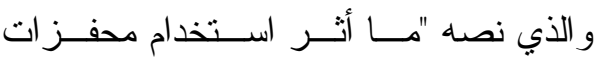
الألعاب الرقمية في تتمية الجو انب المعرفيــة المرتبطة بمهار ات تصميم مو اقع الويب لدى تلاميذ الحلقة الإعدادية؟" للإجابة على سؤال
مو اقع الويب ومهار ات التفكير البصري لدى

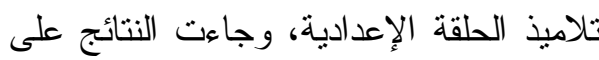

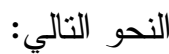
للإجابة على السؤال الأول للبحــث، و الذي نصه "ما مهار ات تــصميم المواقــع الإككترونية اللازم تو افر ها لدى تلاميذ الحلقة

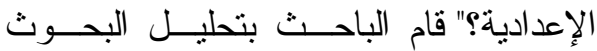
و الدر اسات السابقة في مجال تصميم مواقـع لـع الويب بوجه عام، و التصميم بلغــة HTML بوجه خاص، كما قام بتحليل محتوى كتــاب الصف الثاني الإعدادي- الفـصل الدراســي الأول؛ و الذي يتضمن تصميم مواقع الويـبـ بلغة HTML، وتم عـرض القائمسـة علـى مجموعة من الخبر اء و المحكمين في مجــال تكنولوجيا التعليم، وبعد إجر اء التعديلات تــــ التوصل إلى قائمة المهار ات التي تكونت من

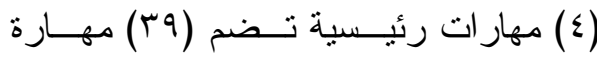
فرعية و (IVT) مهارة اجر ائية.

للإجابة على السؤال الثاني للبحــث،

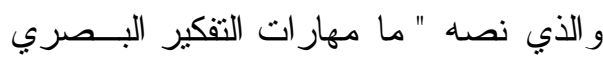

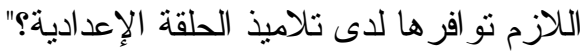

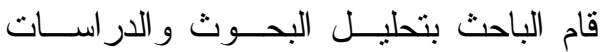
السابقة في مجال مهار ات التفكير البـصري، ومدى مناسبتها لطبيعــة مهــار ات تــصميم مو اقع الويب وطبيعة عينة البحث من تلاميذ مدئ الصف الثاني الإعدادي، وتم عرض القائمــة على مجموعة من الخبراء و المحكمين فـي عي الإسي 
بمهار ات تــصميم مواقــع الويــب لــصالح

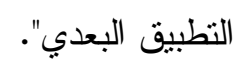

قـــام الباحــث بــــاجر اء اختبـــار ت ت

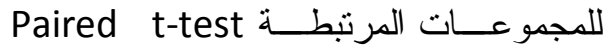
لدرجات النطبيقين القبلي و البعدي Sample لهجموعة البحـــث التجريبيــة فــي اختبـــار الجو انب المعرفية المرتبطة بمهار ات تصميم مو اقع الويب، وذلك وفق الجدول التالي:
البحث قام الباحث بالتحقق من صحة فروض

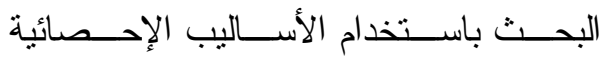
المناسبة، وذلك على النحو التالي: بالي: التحقق من صـــة الفــرض الأول، و الذي نصه: "يوجد فرق ذو دلالة إحـصائية عند مستوى (0. . •) بين متوسطي درجـات المجموعة التجريبية التي درست باسـتخدام

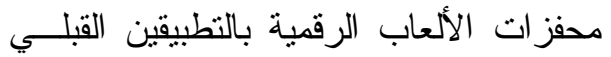
و البعدي لاختبار الجوانب المعرفية المرتبطة

جدول (•) الفروق بين متوسطات درجات التطبيقين القبلي والبعدي للمجموعة التجريبية في اختبار الجوانب المعرفية المرتبطة بمهارات تصميم مواقع الويب دوبن

\begin{tabular}{|c|c|c|c|c|c|c|c|}
\hline الدلالة & مستوى الدلالة & قيمة ت & الحرية & $\varepsilon$ & p & اللارجة العظمى & القياس \\
\hline \multirow{2}{*}{ دالة عند ه.,. } & \multirow{2}{*}{$\cdot, \cdot$} & \multirow{2}{*}{$01,1 \leqslant \varepsilon$} & \multirow{2}{*}{ rq } & I,YT & Ir & \multirow{2}{*}{ rq } & القبلي \\
\hline & & & & $1, \wedge 9 \varepsilon$ & rr & & البعدي \\
\hline
\end{tabular}

المحسوبة تساوي (·, (·,) وهي أقــل مــن (0., (·)، مما يعني وجود فرق دال احصائيا بين متوسطي درجــات التطبيقة لـين القبلــي و البعدي فــي اختبــار الجو انـــب المعرفيــة

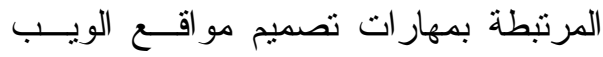

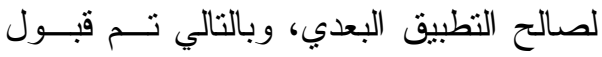

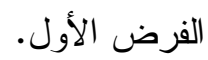

ويفسر الباحث ذلــــــــــأن محفــزات الألعاب الرقمية قد ســاعدت علــى زيــادة

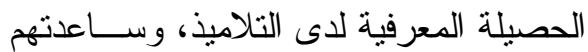

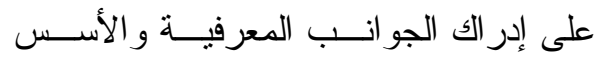
النظرية التي تبنى عليها مهـــار ات تــصميم
يتضح من الجـدول الــسابق وجــود

فروق بين منوسطي درجات النطبيقين القبلي و البعـــي للمجموعـــة التجريبيــة باختبــار الجو انب المعرفية المرتبطة بمهار ات تصميم مو اقع الويب لصالح النطبيق البعدي، حيــث

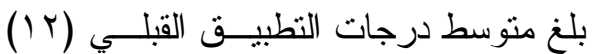

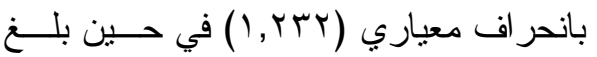

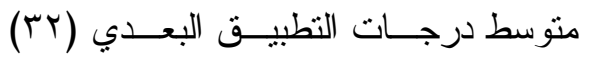

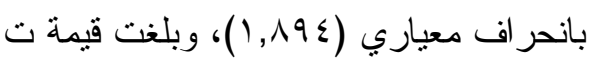

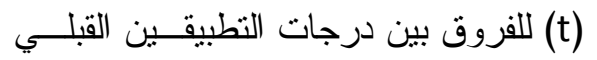

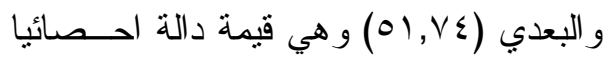
عند مستوى دلالة (0., •))، حيث إن الد لالة 


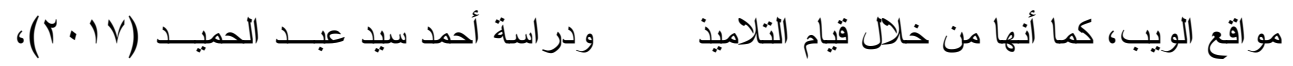

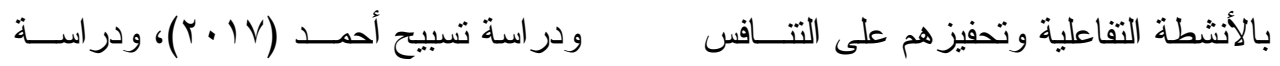

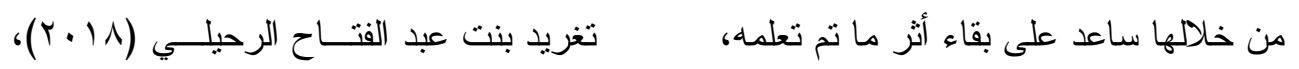

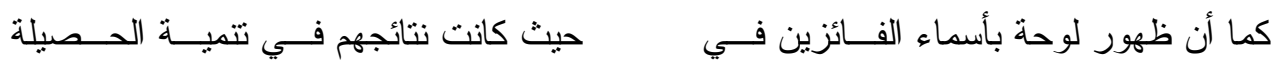

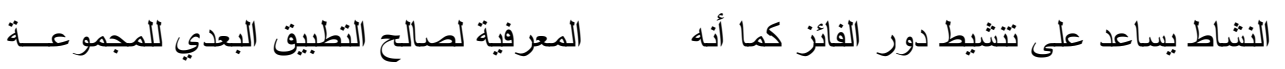

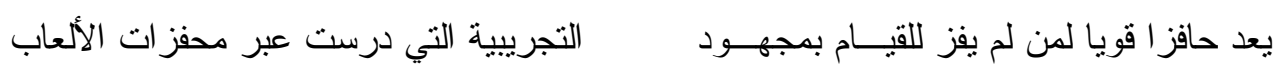
أكبر في التعلم للفوز في الأنشطة التالية، كما ل الرقمية. التحقق من صحة الفــرض الثــــي،

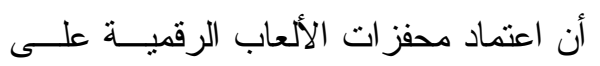

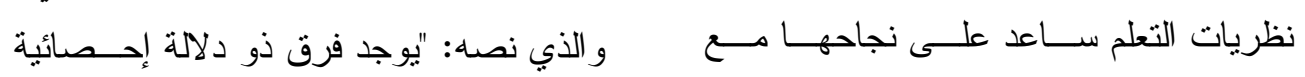

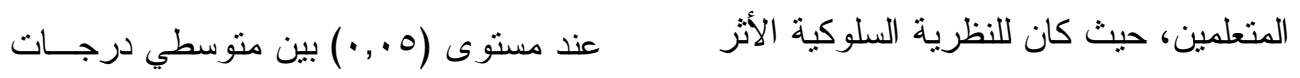

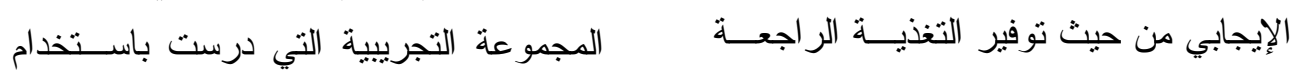

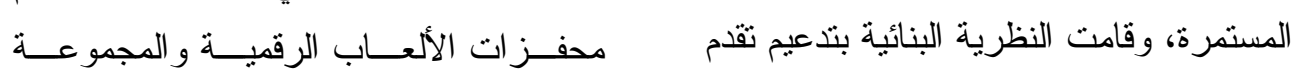
الضابطة التي درست بالطريقة التقليدية فــي التئي اختبار الجوانب المعرفية المرتبطة بمهار ات بهرئه

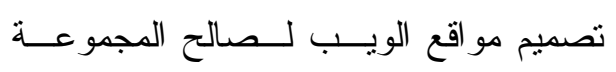
التجريبية" قـــام الباحســث بـــإجر اء اختبـــار ت ت

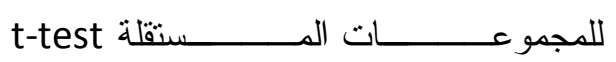
Independent Sample مجمو عتي البحث التجريبية و الضابطة فـي النطبيق البعدي لاختبار الجوانب المعرفيــة

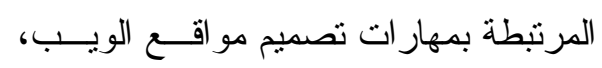
وذللك وفق الجدول التالي: التلاميذ من مستوى لآخر معتمدين على مــا

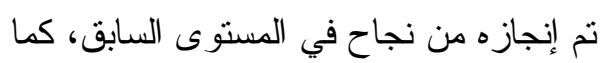

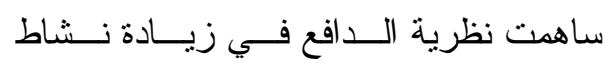
المتعلمين ومثابرتهم على التقدم في التعلم من

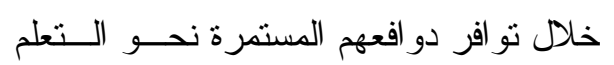

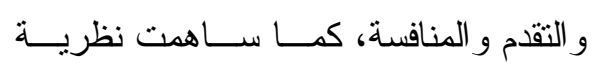

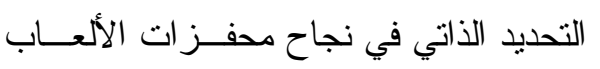
الرقمية من خلال تو افر آليات التحكم الداخلية

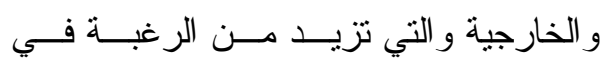

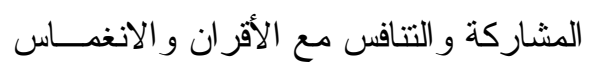

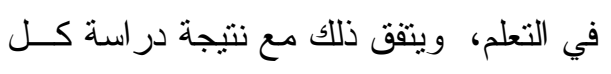

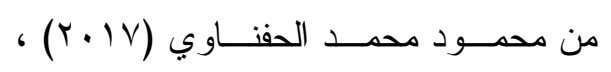


جدول (†) الفروق بين متوسطات درجات المجموعتين التجريبية و الضابطة في التطبيق البعدي لاختبار الجوانب المعرفية المرتبطة بمهارات تصميم مواقع الويب

\begin{tabular}{|c|c|c|c|c|c|c|c|}
\hline الدلالة & الالالة & قيمة ت & الحرية & $\varepsilon$ & P & العظمى & المجموعة \\
\hline \multirow{2}{*}{ دالة عند . . } & \multirow{2}{*}{$\cdot, \ldots$} & \multirow{2}{*}{ T } & \multirow{2}{*}{01} & 1,1799 & $10,1$. & \multirow{2}{*}{$r$} & الضابطة \\
\hline & & & & $1, \wedge 9 \varepsilon$ & r & & التجرييية \\
\hline
\end{tabular}

ويفسر الباحث ذللك بـــأن المجموعــة

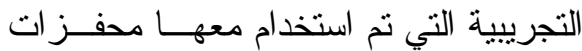

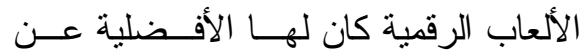
المجموعة الضابطة التي مارست الأنـشنة بشكل تقليدي، هذا بالاضافة إلى أنه تم بنـــاء الأنشطة ونم تحديد طريقة التفاعل معها من خلال محفز ات الألعاب الرقمية بما يتفق مع خصائص التلاميذ وبما يتتاسب مــع فئـتهم

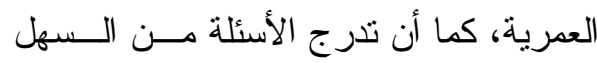

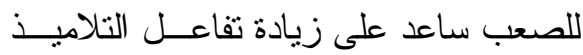

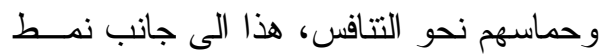
التحفيز المميز الذي يقدم من خلال محفزات

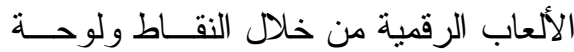

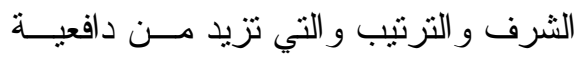

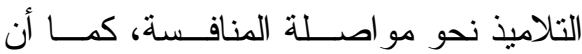

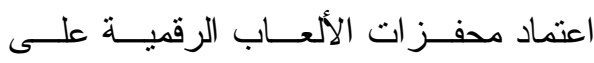

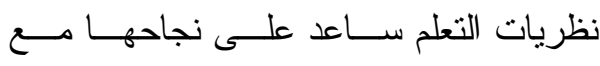

المتعلمين، حيث كان للنظرية السلوكية الأثر

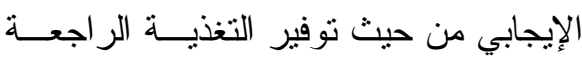
المستمرة، وقامت النظرية البنائية بتدعيم تقدم التلاميذ من مستوى لآخر معتمدين على مــا
يتضح من الجــدول الــسابق وجــود فروق بين متوسطي درجــات المجمــوعتين

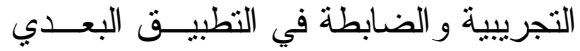
لاختبار الجو انب المعرفية المرتبط بمهار ات تصميم مو اقع الويــب لــصالح المجموعـــة

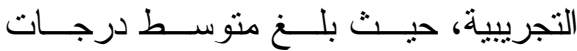

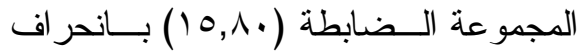

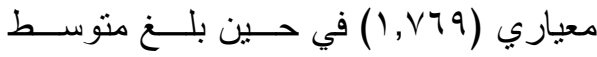
درجات المجمو عة التجرييية (rr) بانحر اف لفين

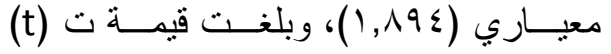
للفروق بــين درجــات النطبيــق البعـدي

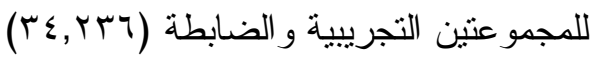
و هي قيمة دالة احصائيا عند مستوى دلالـــة (0.0., (•)، حيث إن الدلالة المحسوبة تـساوي

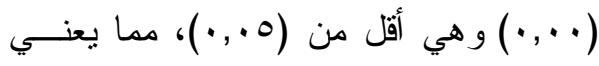

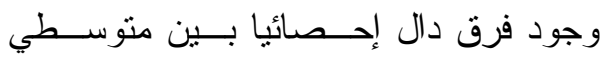
درجات المجموعتين التجريبية، والــضابطة

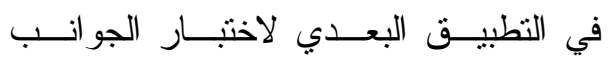

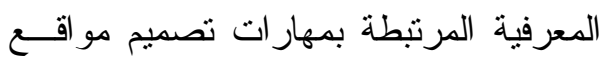
الويب لصالح المجموعة التجريبية، وبالتــالي

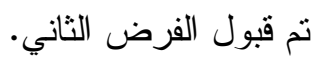




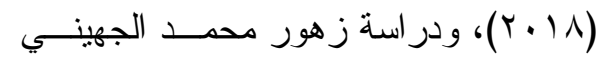

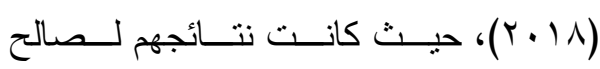

المجمو عة التجريبية التي درست بمحفــزات ات التهات

الألعاب الرقمية مقابل المجموعة الضابطة.

التحقق من صحة الفــرض الثالـــث،

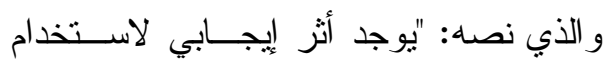

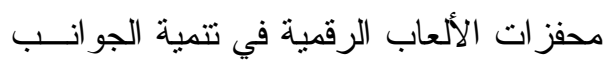

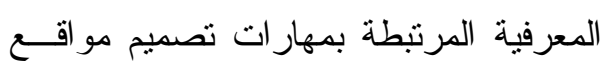

الويب لدى تلاميذ الحلقة الإعدادية"

قام الباحث بحساب مربع ايتا وحساب

حجم الأثر لاستخدام محفزات الألعاب

الرقمية في تتمية الجوانب المعرفية المرتبطة

بمهارات تصميم مواقع الويب لدى تلاميذ

الحلقة الإعدادية، وذلك وفق الجدول التالي:
تم إنجازه من نجاح في المستوى السابق، كما

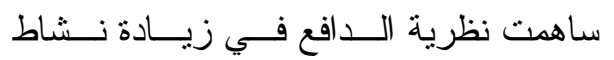

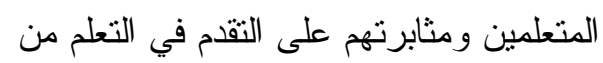
خلال تو افر دو افعهم المستمرة نحسـو الــتعلم

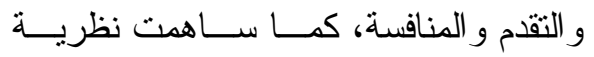

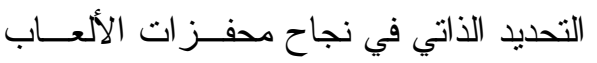
الرقمية من خلال نو افر آليات التحكم الداخلية

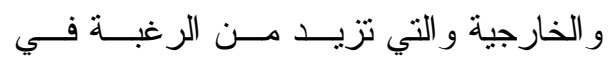

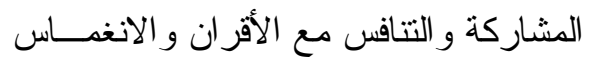
في التعلم، ويتفق ذلك مع نتيجة در ساسة كل

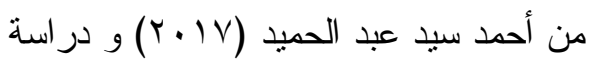

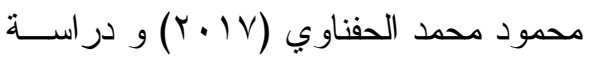

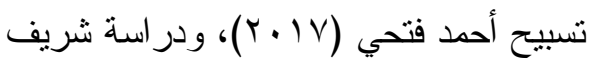

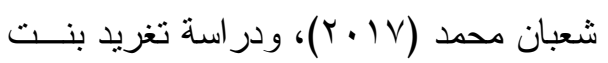

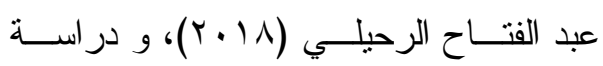
زكريا جابر حناوي وماريان ميلاد منــصور الرحي

جدول (V) حساب مربع ايتا وقياس حجم أثر استخدام محفزات الألعاب الرقمية في تنمية الجوانب المعرفية المرتبطة بمهارات تصميم مواقع الويب لدى تلاميذ الحلقة الإعدادية

\begin{tabular}{|c|c|c|c|c|c|c|}
\hline حجم الأخز & مريع & المجموعة & الأثخ & مريع & 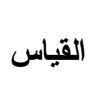 & 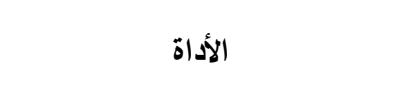 \\
\hline \multirow{2}{*}{ 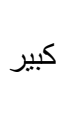 } & \multirow{2}{*}{$\cdot, 904$} & الضابطة & \multirow{2}{*}{ 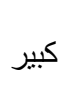 } & \multirow{2}{*}{$\cdot, 9 \wedge 9$} & 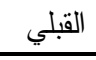 & اختبار الجوانب المعرفية المرتبطة \\
\hline & & التجريية & & & 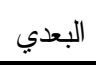 & بمهارات تصميم مواقع الويب \\
\hline
\end{tabular}

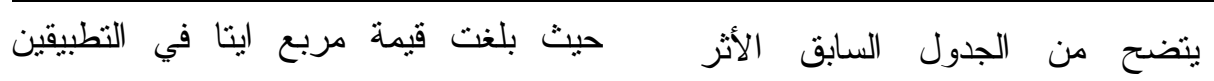

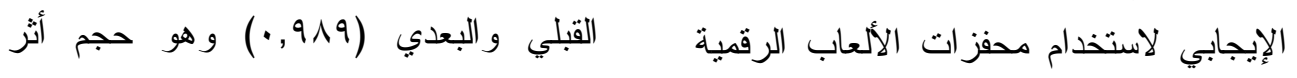

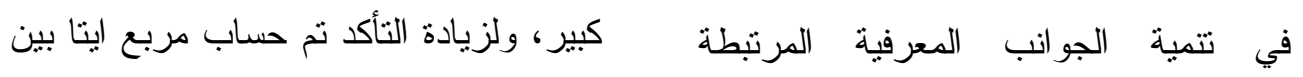
بمهار ات تصميم مواقع الويب، ونت اثبات المجموعنين التجريبية والضابطة في النطبيق ذللك من خلال حساب مربع ايتا وحجم الأثر، البعدي لاختبار الجوانب المعرفية المرنبطة 
المستمرة، وقامت النظرية البنائية بتدعيم تقدم التلاميذ من مستوى لآخر معتمدين على مـــا

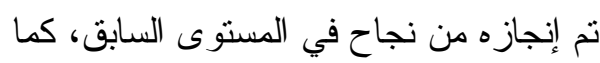

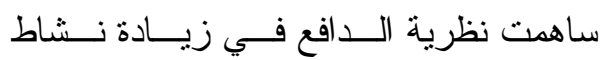
المتعلمين ومثابرتهم على التقدم في التعلم من

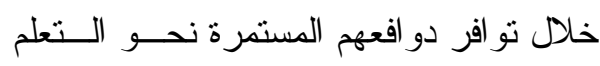

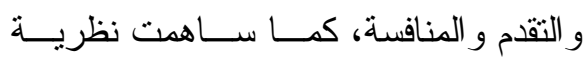

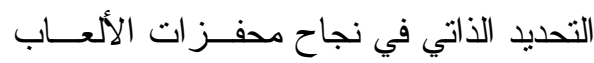
الرقية من خلال تو افر آليات التحكم الداخلية

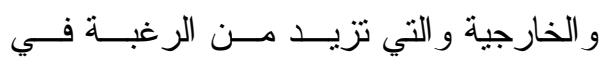

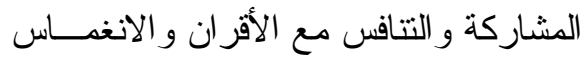

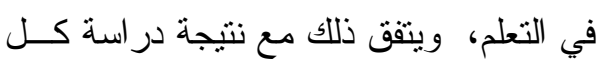

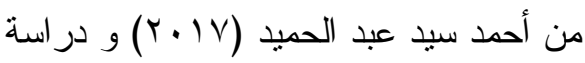

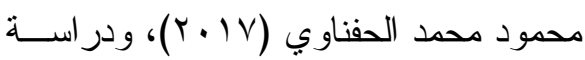

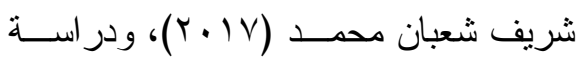

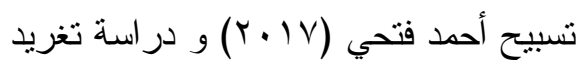

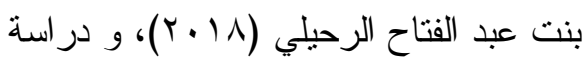
زكريا جابر حناوي وماريان ميلاد منــصور

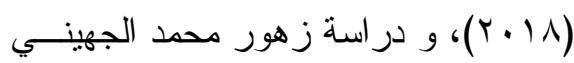
$\cdot(r \cdot 1 \Lambda)$ للإجابة على السؤال الخامس للبحث،

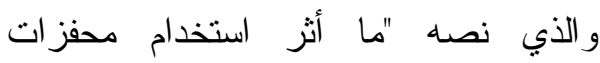
الألعاب الرقمية في تتمية الجوانب الأدائية المرتبطة بمهار ات تصميم مواقع الويب لدى لـى لاديه تلاميذ الحلقة الإعدادية؟"، للإجابة على سؤ ال البحث قام الباحث بالتحقق من صحة فروض الإنه
بمهار ات تصميم مواقع الويب و التي بلغت

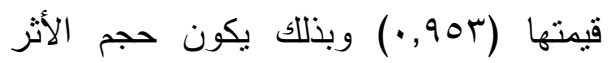
كبير أيضا، مما يعني أنه يوجد أثز إيجابي لاستخدام محفز ات الألعاب الرقمية في تتمية لئية الجو انب المعرفية المرتبطة بمهار ات تصميم مواقع الويب لاى نلاميذ الحلقة الإعدادية، وبالتالي تم قبول الفرض الثالث للبحث. ويفسر الباحث ذلك: بــأن محفــز ات

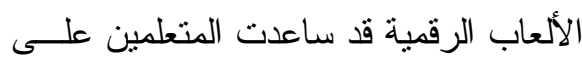
تتمية جو انبهم المعرفية بما يتعلق بمهــار ات لتحست

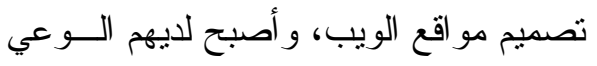

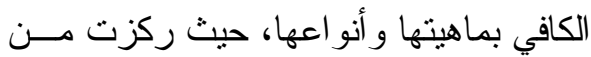

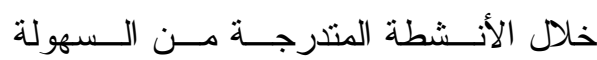
للصعوبة علـى التفاعـلـ مــع المتعلمــين

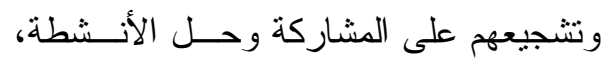

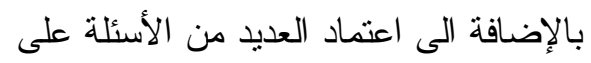

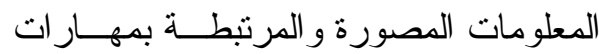
تصميم مو اقع الويب و التي بدور ها تـسـاعد

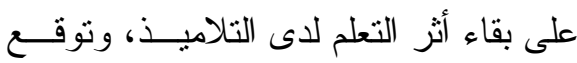

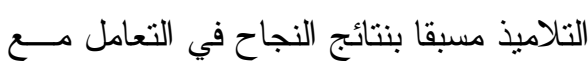

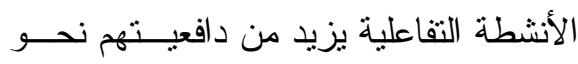
الاجتهاد للوصول لمستوى أفضل، و الحصول دئل

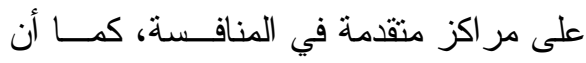

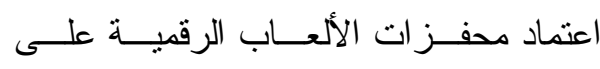

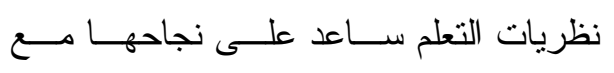
المتعلمين، حيث كان للنظرية السلوكية الأثر

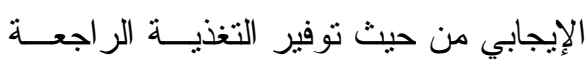




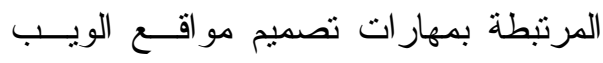

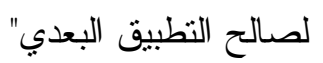

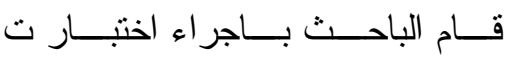

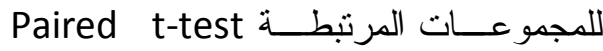
Sample لدرجات النطبيقين القبلي و البعدي لمجموعة البحث التجريبية في بطاقة ملاحظة الجو انب الأدائية المرتبطة بمهار ات تــصميم مو اقع الويب، وذلك وفق الجدول التالي:
البحث باستخدام الأساليب الإحصائية المناسبة، وذلك على النحو التالي:

و الذي نصد: "يوجد فرق ذو دلالة إحسصائية عند مسنوى (0. . •) بين منوسطي درجـات المجموعة التجريبية التي درست باسـتخدام محفز ات الألعاب الرقمية بالتطبيقين القبالـي لـي و البعدي لبطاقة ملاحظة الجوانــب الأدائيـــة جدول (^) الفروق بين متوسطات درجات التطبيقين القبلي والبعدي للمجموعة التجريبية في

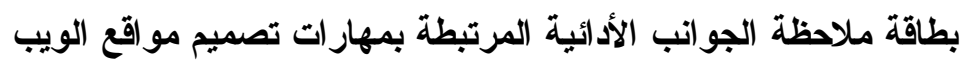

\begin{tabular}{|c|c|c|c|c|c|c|c|}
\hline اللالة & مستوى الدلالة & قيمة ت & درجة الحرية & $\varepsilon$ & p & العظمى & القياس \\
\hline \multirow{2}{*}{ د. . ,. } & \multirow{2}{*}{$\cdot, \ldots$} & \multirow{2}{*}{$T V, 1$} & \multirow{2}{*}{ rq } & $r_{,} \cdot \varepsilon$ & $\varepsilon r, 1$ & \multirow{2}{*}{ IKT } & القبلي \\
\hline & & & & $r, 010$ & $q \wedge, r$ & & البعدي \\
\hline
\end{tabular}

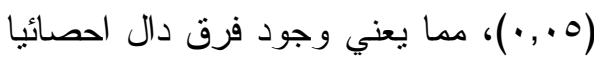
بين متوسطي درجــات التطبيةـين القبلــي يتضح من الجـدول الــسابق وجــود و البعدي في بطاقة ملاحظة الجوانب الأدائية فروق بين منوسطي درجات النطبيقين القبلي

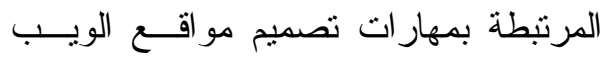
و البعدي للمجمو عة التجريبية ببطاقة ملاحظة

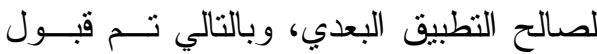
الجو انب الأدائية المرتبطة بمهار ات تـصميم

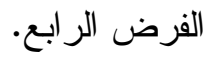
مو اقع الويب لصالح النطبيق البعدي، حيــث

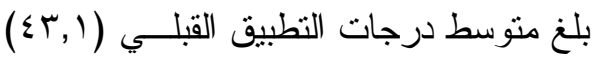

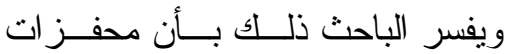

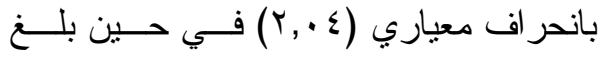
الألعاب الرقمية قد ســاعدت علــى تتميــة منوسط درجات النطبيـق البعـدي (؟1)

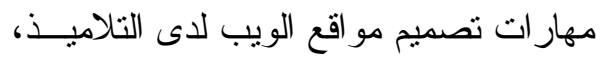
بانحر اف معياري (r.010)، وبلغت قيمة ت

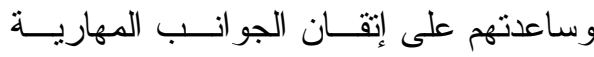
للفروق بين درجات التطبيقـين القبلــي (t)

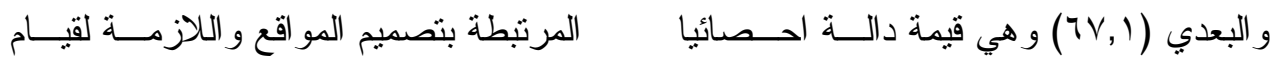

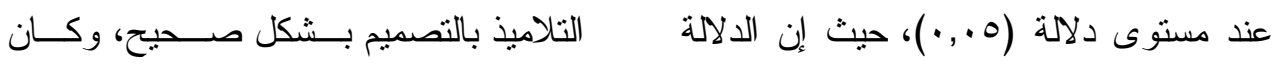

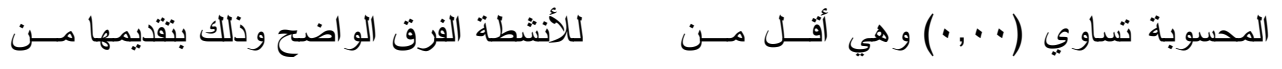


مع نتيجة در اسة كل من تسبيح أحمد فتحسي

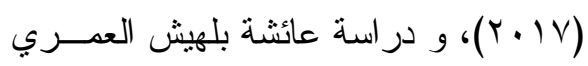

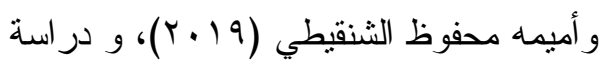
زكريا جابر حناوي وماريان ميلاد منــصور

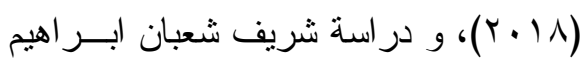

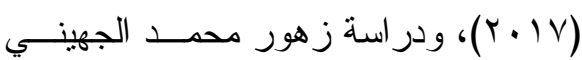
$\cdot(r \cdot 1 \Lambda)$

التحقق من صحة الفرض الخــامس،

و الذي نصه: "يوجد فرق ذو دلالة إحــصائية عند مسنوى (0. . • ) بين متوسطي درجــات المجموعة التجريبية التي درست باســتخدام

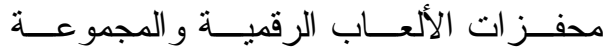
الضابطة التي درست بالطريقة التقليدية فـي ولئ بطاقة ملاحظة الجوانب الأدائيــة المرتبطــــة

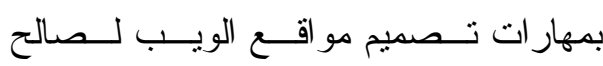

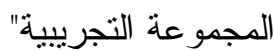

قـــام الباحـــث بـــإجر اء اختبـــار ت ت

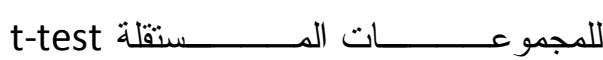
Independent Sample مجموعتي البحث التجريبية و الضابطة فـي

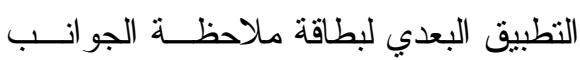

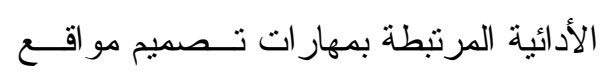
الويب، وذلك وفق الجدول التالي:
خلال محفزات الألعاب الرقمية، فهي تعتـــد

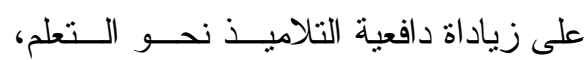
و التسابق من أجل الفـــوز، وبالتــالي يـــنق التلاميذ هذه المهار ات من خــلال الأنـشطة التفاعلية و التي تحفز هم على المشاركة الفعالة للوصول للتزتيب الأفضل و الحصول علـى ولى لـي

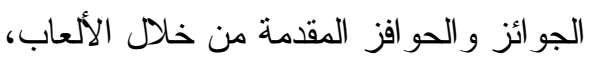
و اتضح ذلك الفرق من خلال المقارنة بــين درجات التطبيقين القبلي و البعـدي لبطاقــة

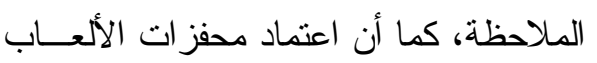

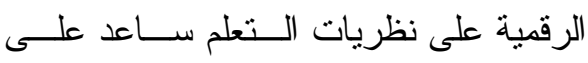

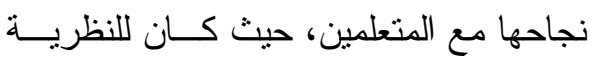

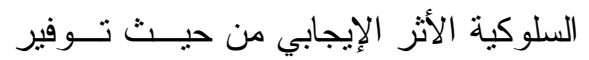

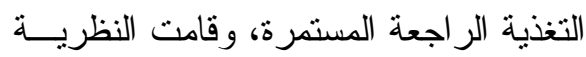
البنائية بتدعيم تقدم التلاميذ من مستوى لآخر

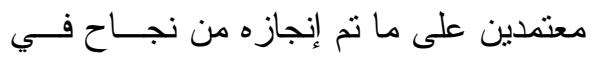

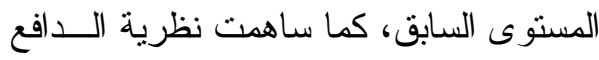

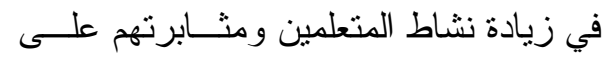

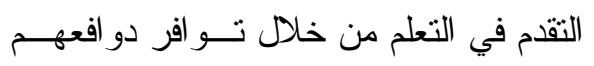

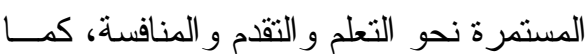

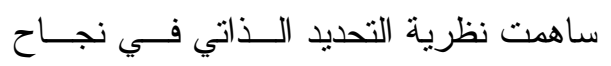

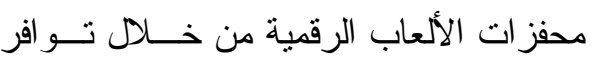
آليات التحكم الداخلية و الخارجية و التي تزيد

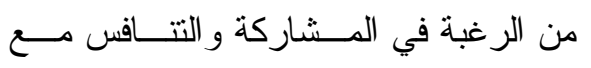

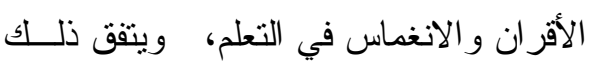


جدول (9) الفروق بين متوسطات درجات المجموعتين التجريبية والضابطة في التطبيق البعدي

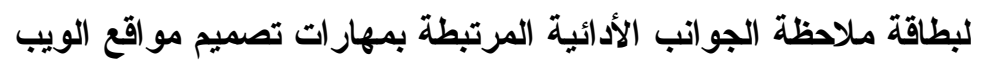

\begin{tabular}{|c|c|c|c|c|c|c|c|}
\hline الدلالة & مستوى الدلالة & قيمة ت & درجة الحرية & $\varepsilon$ & r & العظمى & لمجموعة \\
\hline \multirow{2}{*}{ ه ..,. } & \multirow{2}{*}{$\cdot, \cdots$} & \multirow{2}{*}{$7 \varepsilon, 9$} & \multirow{2}{*}{01} & r,Arq & $\varepsilon \varepsilon, \wedge r$ & \multirow{2}{*}{ ITr } & الضابطة \\
\hline & & & & $r, 010$ & $9 \Lambda, r$ & & التجريبية \\
\hline
\end{tabular}

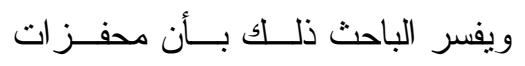

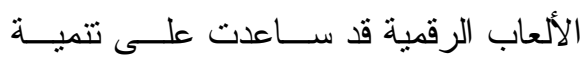

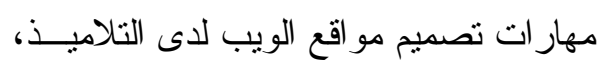

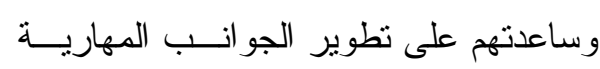

المرتبطة بتصميم المو اقع و اللازمــــة لقيــام

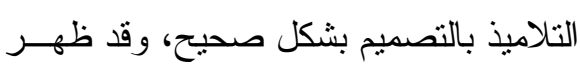

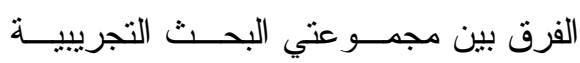

و الضابطة؛ حيث إن تقوق درجات المجموعة مجئ

التجريبية في بطاقة الملاحظة عن المجموعة

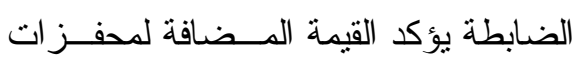

الألعاب الرقية، فقد كان للأنــشطة الفــرق

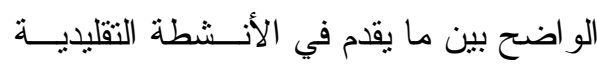

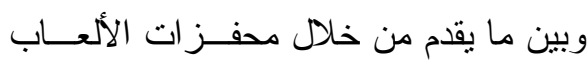

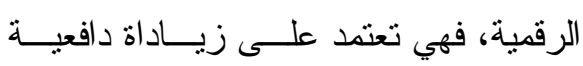

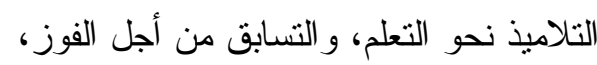

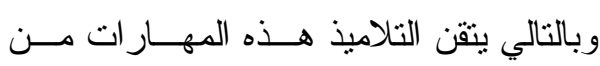

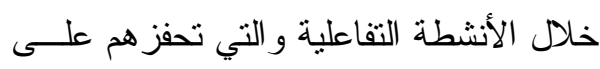

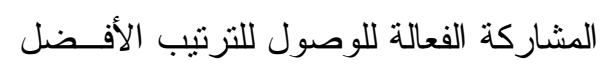

و الحصول على الجوائز و الحو افز المقدمسـة

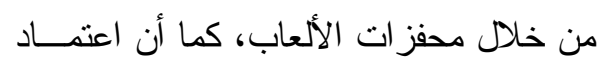
محفزات الألعاب الرقمية على نظريات التعلم
يتضح من الجــدول الــسابق وجــود

فروق بين متوسطي درجــات المجمــوعتين التجريبية و الضابطة في التطبيــق البعـدي لرئي

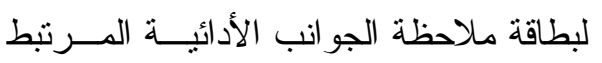

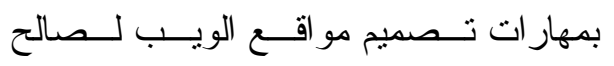

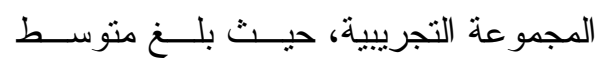

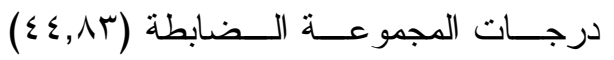

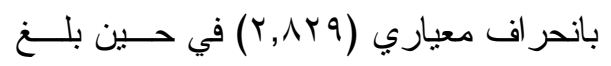

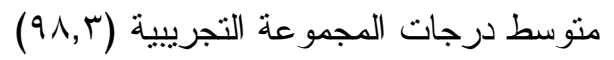

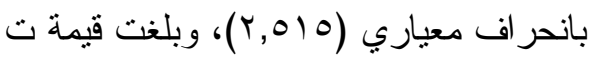

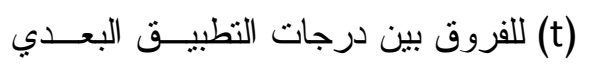

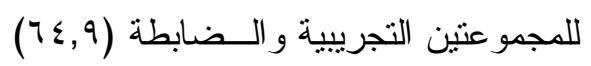
وهي قيمة دالة احصائيا عند مستوى دلالـــة (0. (•) )، حيث إن الدلالة المحسوبة تـساوي

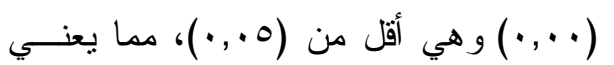

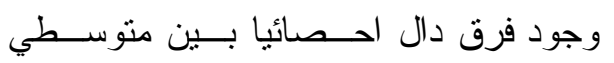
درجات المجمو عتين التجريبية و الضابطة في دوني

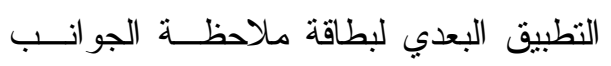

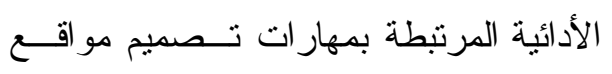

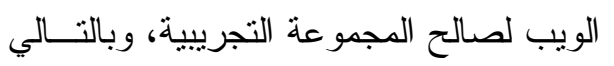
تم قبول الفرض الخامس. 
أميمه محفوظ الثنقيطي (9 19 ـ (Y)، ودر اســـة زكريا جابر حناوي وماريان ميلاد منــصور

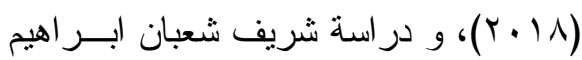

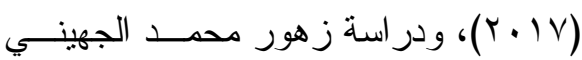
$\cdot(r \cdot 1 \Lambda)$

التحقق من صحة الفرض الـسـادس،

و الذي نصه: "يوجد أثز إيجـابي لاســتخدام

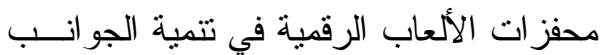
الأدائية المرتبطة بمهار ات تــصميم مو اقــع

الويب لاى تلامبذ الحلقة الإعدادية"

قام الباحث بحساب مربع ايتا وحساب حجم الأثز لاستخدام محفزات الألعاب له الرقمية في تتمية الجوانب الأدائية المرنبطة بمهار ات تصميم مواقع الويب لدى تلاميذ الحلقة الإعدادية، وذللك وفق الجدول التالي:

ساعد على نجاحها مع المتعلمين، حيث كان للنظرية السلوكية الأثز الإيجابي من حبــث توفير التخذية الر اجعة المـستمرة، وقامــــ النظرية البنائية بتدعيم تقــدم التلاميــذ مــن مستوى لآخر معتمدين على ما تم إنجازه من نجاح في المستوى السابق، كمــا ســـاهمت نظرية الدافع في زيــادة نــشاط المتعلمــين ومثثابرتهم على التقدم في التعلم مــن خـــلال تو افر دو افعهم المستمرة نحو التعلم و التقــدم و المنافسة، كما ساهمت نظرية التحديد الذاتي في نجاح محفز ات الألعاب الرقمية من خلال تو افر آليات التحكم الداخلية و الخارجية والتي تزيد من الرغبة في المشاركة و التتافس مسـع

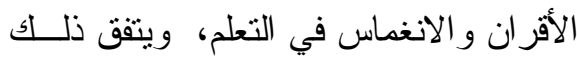
مع نتيجة در اسة كل من تسبيح أحمد فتحـي (Y IV) جدول ( • 1) حساب مربع ايتا وقياس حجم أثر استخدام محفزات الألعاب الرقمية في تتمية الجواتب الأدائية المرتبطة بمهار ات تصميم مواقع الويب لاى تلاميذ الحلقة الإعدادية

\begin{tabular}{|c|c|c|c|c|c|c|}
\hline الأثر & ايتا & المجموعة & الأثر & ايتا & القياس & الأداة \\
\hline \multirow{2}{*}{ كبير } & \multirow{2}{*}{$\cdot, 9 \wedge 7$} & الضـابطة & \multirow{2}{*}{ كبير } & \multirow{2}{*}{$\cdot, 99 \leq$} & القبلي & \multirow{2}{*}{ بطاقة ملاحظة الجوانب الأدائية المرتبطة } \\
\hline & & التجريبية & & & البعدي & \\
\hline
\end{tabular}
يتضح من الجدول السابق الأثز بلغت قيمة مربع ايتا في التطبيقين القبلي

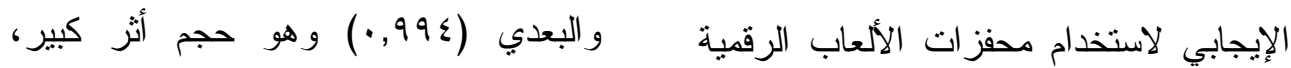
في تتمية الجو انب الأدائية المرثتبة بمهار ات ولزيادة التأكد تم حساب مربع ايتا بين تصميم مواقع الويب، وتم إثبات ذلك من المجموعتين التجريبية و الضابطة في التطبيق خلال حساب مربع ايتا وحجم الأثر، حيث البعدي لبطاقة ملاحظة الجوانب الأدائية 
الإيجابي من حيث توفير التغذيــة الراجعـة المستمرة، وقامت النظرية البنائية بتدعيم تقدم التلاميذ من مستوى لآخر معتمدين على مـــا

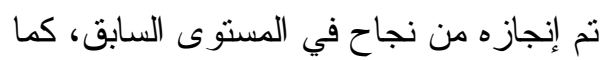

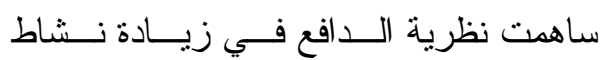
المتعلمين ومثابرتهم على التقدم في التعلم من خلال تو افر دو افعهم المستمرة نحـــــو الــتعلم

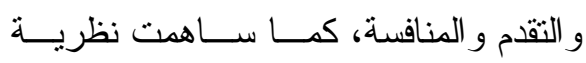

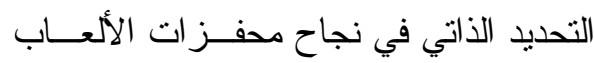
الرقمية من خلال تو افر آليات التحكم الداخلية

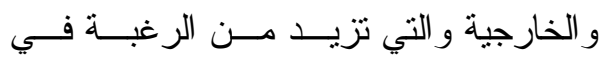

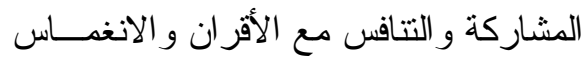
في التعلم، ويتقق ذلك مع نتيجة در اسة كـلـل

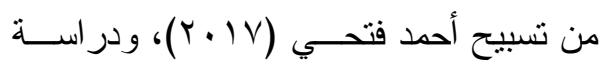

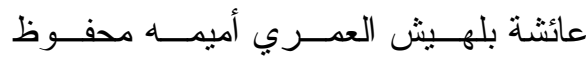

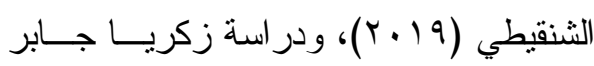

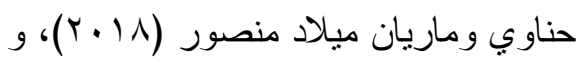

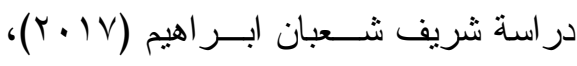

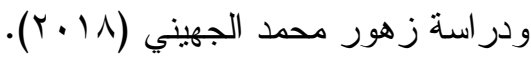
للإجابة على السؤال السادس للبحث، و الذي نصه " ما أثز استخدام محفزات الألعاب الرقمية في تتمية مهارات التفكير

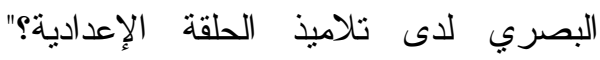
للإجابة على سؤال البحث ثقام الباحث بالتحقق من صحة فروض البحث باستخدام

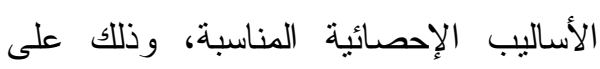

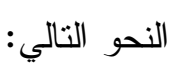

لمهارات تصميم مواقع الويب و التي بلغت

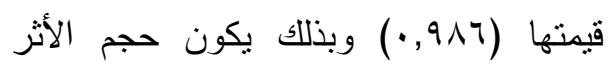
كبير أيضا، وبذلك يتم قبول الفرض السادس وبن لهن للبحث، أي أنه يوجد أثز إيجابي لاستخدام

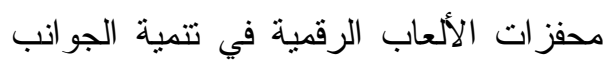

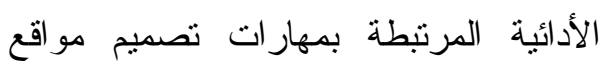
الويب لدى تلاميذ الحلقة الإعدادية. ويفسر الباحث ذلك: بـــأن محفــز ات

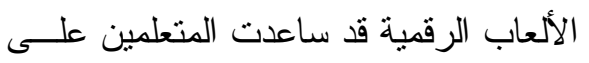

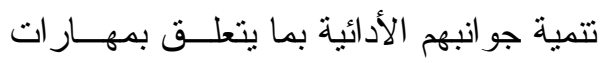

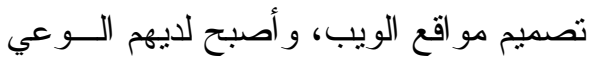

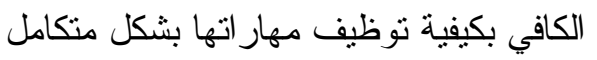
للحصول على منتج (موقع الكتروني)، حيث

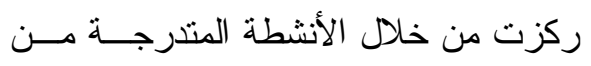
السهولة للصعوبة على التفاعل مع المتعلمين

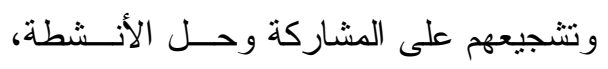

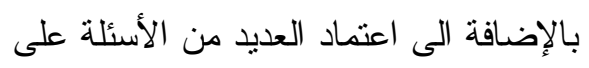

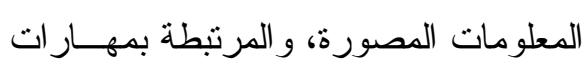
تصميم مو اقع الويب و التي بدور ها تـسـاعد وليد

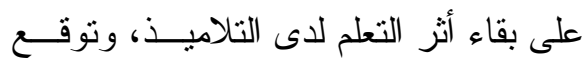

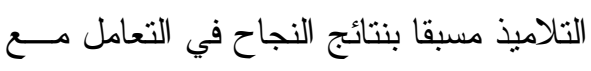

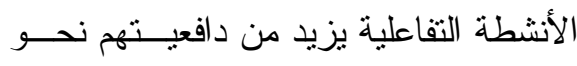

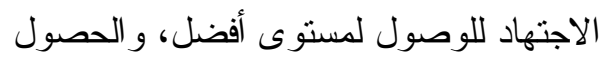

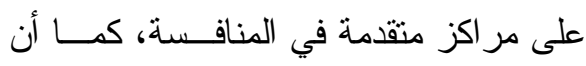

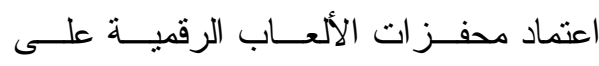

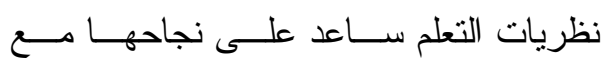
المتعلمين، حيث كان للنظرية السلوكية الأثر نجري 


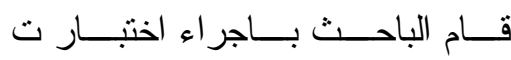

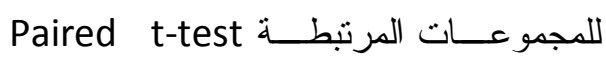
لدارجات التطبيقين القبلي و البعدي Sample لمجموعة البحـــث التجريبيــة فــــي مقيــاس مهار ات التفكير البصري، وذللك وفق الجدول

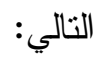

\section{التحقق من صحة الفرض الـسـابع،}

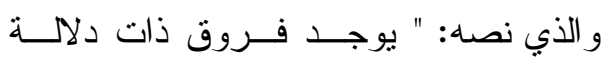

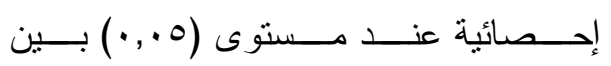
متوسطات درجات المجموعة التجريبية التي درست باستخدام محفز ات الألعاب الرقميــة

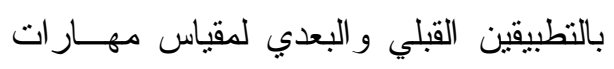
التفكير البصري لصالح النطبيق البعدي" لبهي"

جدول (11) الفروق بين متوسطات درجات التطبيقين القبلي و البعدي للمجموعة التجريبية في

\begin{tabular}{|c|c|c|c|c|c|c|c|c|}
\hline الدلاةة & مستوى الدلالة & قيمة ت & الحرجة & $\varepsilon$ & p & العظمى & القياس & المحور \\
\hline \multirow{2}{*}{ دالة عند } & \multirow[b]{2}{*}{$\cdot, \cdots$} & \multirow[b]{2}{*}{$r r, \leqslant 00$} & \multirow[b]{2}{*}{ rq } & $1, \leqslant 00$ & $1 \cdot, 0 \mathrm{~V}$ & \multirow[b]{2}{*}{ r. } & القبلي & \multirow{2}{*}{ الذاكرية } \\
\hline & & & & $r, \cdot r T$ & $r, 1$ & & البعدي & \\
\hline \multirow{2}{*}{ د. د., عند } & \multirow{2}{*}{$\cdot, \cdots$} & \multirow{2}{*}{$r r, r \vee \wedge$} & \multirow{2}{*}{ rq } &., 0.9 & 1,0 & \multirow{2}{*}{$\wedge$} & القبلي & \multirow{2}{*}{ الإلصر اك } \\
\hline & & & &., 071 & $0,0 \mathrm{~V}$ & & البعدي & \\
\hline \multirow{2}{*}{ د. د., عند } & \multirow{2}{*}{$\cdot, \cdots$} & \multirow{2}{*}{$r, T \wedge V$} & \multirow{2}{*}{ rq } & $\cdot, 0 . \mathrm{V}$ & 1,04 & \multirow{2}{*}{ v } & القبلي & \multirow{2}{*}{ التصريز } \\
\hline & & & & זדו,. & $\varepsilon, q$ & & البعدي & \\
\hline \multirow{2}{*}{ د د.الة عند } & \multirow[b]{2}{*}{$\cdot, \cdot \cdot$} & \multirow[b]{2}{*}{$19,8 \leqslant 7$} & \multirow[b]{2}{*}{ rq } & -,$\leqslant 91$ & 1,7 & \multirow[b]{2}{*}{ v } & القبلي & \multirow{2}{*}{ الالتصرل } \\
\hline & & & & •,VIr & $\varepsilon, 9$ & & البعدي & \\
\hline \multirow{2}{*}{ دالة عند } & \multirow{2}{*}{$\cdot, \cdot \cdots$} & \multirow{2}{*}{$r 4, \cdot 10$} & \multirow{2}{*}{ rq } &., $0 . \mathrm{V}$ & $1, \varepsilon V$ & \multirow{2}{*}{ v } & القبلي & \multirow{2}{*}{ الالاسترل } \\
\hline & & & &., 097 & $\varepsilon, V$ & & البعدي & \\
\hline \multirow{2}{*}{ د. د., عند } & \multirow{2}{*}{$\cdot, \cdot$} & \multirow{2}{*}{$r r, \cdot T q$} & \multirow{2}{*}{ rq } & .,974 & $r, I V$ & \multirow{2}{*}{9} & القبلي & \multirow{2}{*}{ البصري } \\
\hline & & & & $\cdot, \leqslant 9$. & $0, \pi T$ & & البعدي & \\
\hline \multirow{2}{*}{ دالة عند } & & (2) & 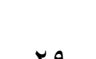 & $r, 1 \cdot r$ & $1 \lambda, \wedge r$ & -1 & القبلي & المقياس \\
\hline & 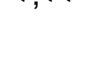 & ו & r & r, ro & $\leq 4, \wedge$ & . & البعدي & الكلي \\
\hline
\end{tabular}




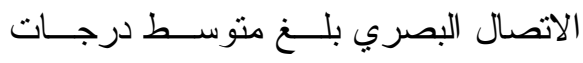

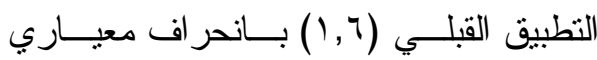

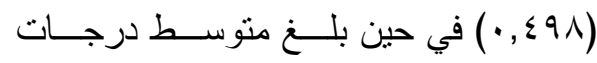

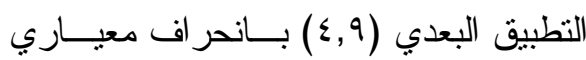

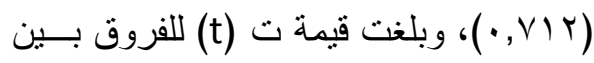

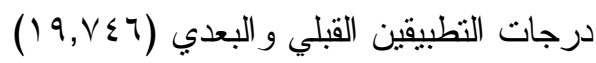

و هي قيمة دالة احصائيا عند مستوى دلالـــة

(0. (•))، وفي محور الاستدلال البصري بلغ

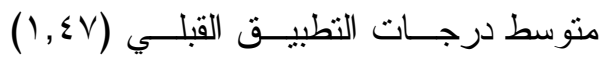

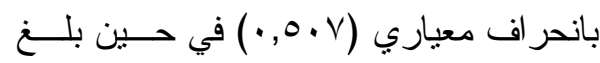

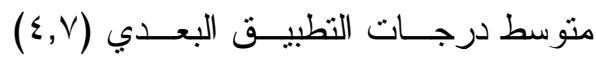
بانحر اف معياري (17 097. ))، وبلغت قيمة ت للفروق بين درجات التطبيةــين القبالـي (t) و البعدي (10 • , r. و) وهي قيمة دالة احصائيا عند مستوى دلالة (0.,.))، وفــي محسـور التحليل البصري بلغ متوسط درجات التطبيق

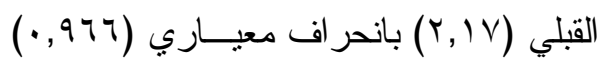
في حين بلغ متوسط درجات التطبيق البعدي

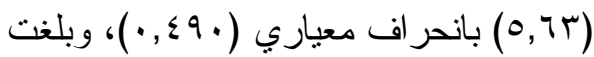
قيمة ت (t) للفروق بين درجات التطبية بـين

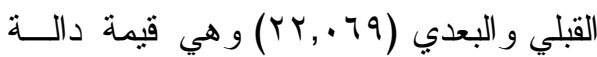
احصائيا عند مستوى دلالة (0. . •)، وأخبر العيل في مقياس مهار ات التفكير البصري الكلــي بلغ متوسط درجات النطبيق القبلي (r,A,A)

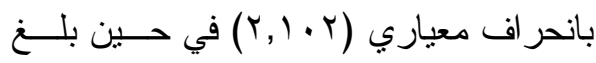
متوسط درجات التطبيـق البعـدي (^, ؟ ؟ بانحر اف معياري (r, ro)، وبلغت قيمــة ت
يتضح من الجــدول الــسابق وجــود

فروق بين متوســطات درجـات التطبية سـين القبلي و البعدي للمجمو عة التجرييية بمحسـاور مقياس مهار ات التفكير البصري وبالمقيــاس الكلي لصالح التطبيق البعدي، ففـي محـــور الذاكرة البصرية بلغ منوسط درجات النطبيق القبلي (0V, • • (1) بانحر اف معياري (00 ـ , 1) في حين بلغ متوسط درجات التطبيق البعدي

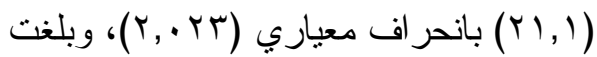
قيمة ت (t) للفروق بين درجات التطبيقـين

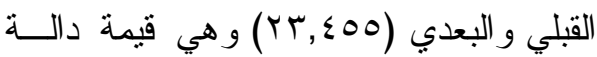
احصائيا عند مستوى دلالة (0., (•)، وفـي محور الإدر الك البصري بلغ متوسط درجات

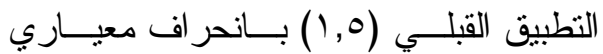

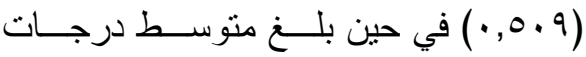

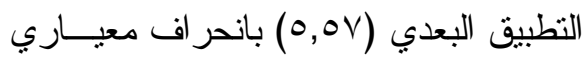

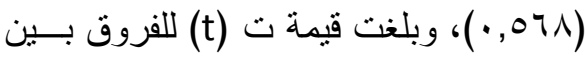

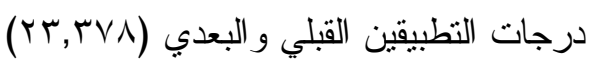
و هي قيمة دالة احصائيا عند مسنوى دلالــــة

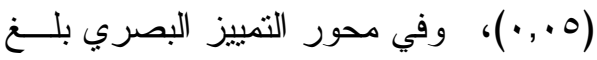

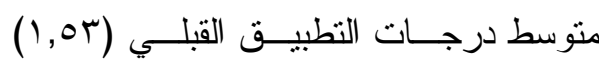

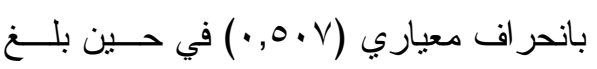

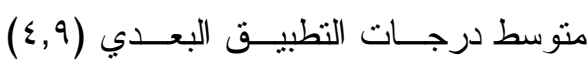

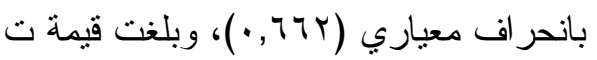
للفروق بين درجات التطبيقـين القبالـي (t) و البعدي (T), TVV) و هي قيمة دالة الحصائيا عند مستوى دلالة (0.,.))، وفـي محسـور 
العروض المصورة ومحاكاة أكثر من بعـد

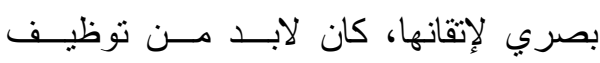

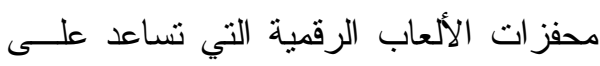

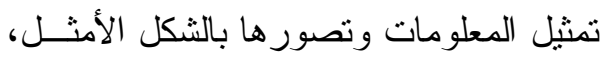
ويتفق ذلك مع نتيجة در اسة كل مــن بليــر (2003) (1lair، ودر اسة فايزة أحمد حمادة

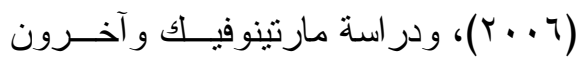
Martinovic et al., (2013) مارشفر انسيـسكو وبر انجيـر - Marache ‘Francisco \& Brangier (2013)

$$
\text { ودر اسة دعاء محمد سيد (10 (r). }
$$

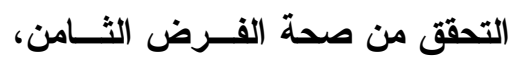

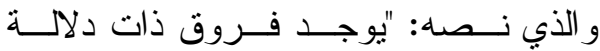

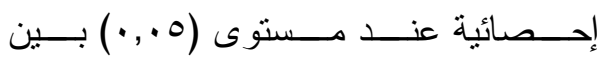
منوسطات درجات المجموعة التجريبية التي درست باستخدام محفزات الألعاب الرقميــة و المجموعة الضابطة التي درست بالطريقـــة التقليدية في مقياس مهار ات التقكير البصري بهري لصالح المجمو عة التجريبية"

قــام الباحسـث بـــإجر اء اختبـــار ت

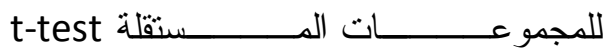
Independent Sample مجمو عتي البحث التجريبية و الضابطة فـي التطبيق البعدي لمقيــاس مهــــار ات التفكيــر البصري، وذلك وفق الجدول التالي: (t) للفروق بين درجات التطبيقــين القبلــي

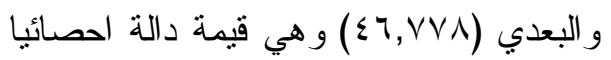
عند مستوى دلالة (0., •·)، وحيث إن الدلالة

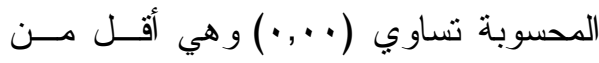
(0. . • ) في جميع محاور المقياس وبالمقياس الكلي، مما يعني وجود فروق دالة احــصائيا

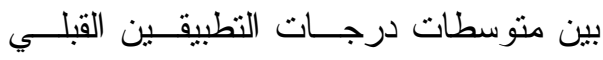
و البعدي في محاور مقياس مهار ات التفكيــر البصري وفي المقياس الكلي لصالح النطبيق البعدي، وبالتالي يتم قبول الفرض السابع.

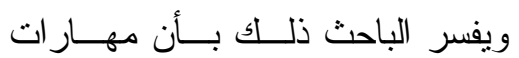
التفكير البصري تحتاج إلــى المزيـــــــن التفاعلية من خلال الأمتلة المقدمة عن طريق المانق

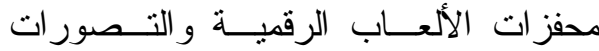

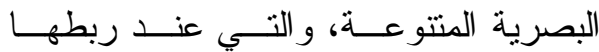
بالجوانب المعرفية و الأدائية لمهار ات تصميم مو اقع الويب تكون في حاجــة إلـى إعــادة

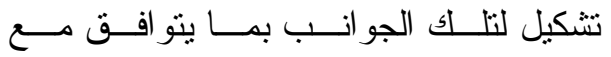
التدريبات البصرية التي تـسـاعد المتعلمـين على التفكير بشكل بصري مصور محسوس ليسهل إداركها، لذا فإن تتمية مهار ات التفكير هُهري

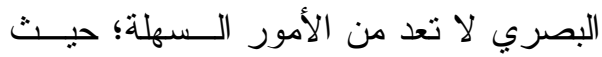

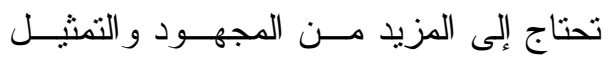
البصري لإتقانها و إمكانية نوظيفها بشكل جيد

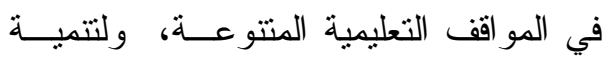

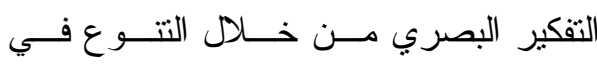




\begin{tabular}{|c|c|c|c|c|c|c|c|c|}
\hline \multirow{2}{*}{ الالطبيق } & \multicolumn{8}{|c|}{ جدول (Y I ) الفروق بين متوسطات درجات المجموعتين التجريبية والضابطة فو البعدي لمقياس مهارات التفكير البصري } \\
\hline & مستوى الدلالة & قيمة ت & الحرجة & $\varepsilon$ & p & الارجة & المجموعة & المحور \\
\hline \multirow{2}{*}{ 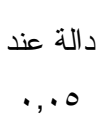 } & \multirow{2}{*}{$\cdot, \cdots$} & \multirow{2}{*}{$r 1, V Y V$} & \multirow{2}{*}{01} & $1, \varepsilon \backslash 1$ & $11, r$ & \multirow{2}{*}{ r. } & الضـابطة & الذاكرة \\
\hline & & & & T, Tr & $r, 1$ & & التجريبية & البصرية \\
\hline \multirow{2}{*}{ 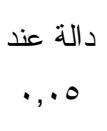 } & \multirow{2}{*}{$\cdot, \cdot$} & \multirow{2}{*}{$r \varepsilon, O r V$} & \multirow[t]{2}{*}{01} & $\cdot, 7 \leq$. & I,Vr & \multirow{2}{*}{$\wedge$} & الضابطة & الإدر اك \\
\hline & & & & $\cdot, 071$ & $0,0 \mathrm{~V}$ & & التجريبية & البصري \\
\hline \multirow{2}{*}{ ه ه. . . } & \multirow{2}{*}{$\cdot, \cdots$} & \multirow{2}{*}{ Yl, Ar. } & \multirow[t]{2}{*}{01} & $\cdot, \leqslant 9 \wedge$ & 1,7 & \multirow{2}{*}{ V } & الضابطة & التميز \\
\hline & & & & צדות, & $\varepsilon, q$ & & التجريبية & البصري \\
\hline \multirow{2}{*}{ ه ه. } & \multirow{2}{*}{$\cdot, \cdots$} & \multirow{2}{*}{$r \cdot, r \ldots$} & \multirow[t]{2}{*}{01} & $\cdot, \leqslant 9$. & 1, 1, & \multirow{2}{*}{ V } & الضابطة & الاتصال \\
\hline & & & & $\cdot, V \backslash Y$ & $\varepsilon, 9$ & & التجريبية & البصري \\
\hline \multirow{2}{*}{ ه ه. . . } & \multirow{2}{*}{$\cdot, \cdots$} & \multirow{2}{*}{ 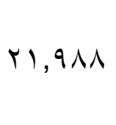 } & \multirow[t]{2}{*}{$0 \wedge$} &., $0 .\{$ & $1,0 \mathrm{~V}$ & \multirow{2}{*}{ V } & الضـابطة & الاستـلال \\
\hline & & & &., 097 & $\varepsilon, V$ & & التجرييية & البصري \\
\hline \multirow{2}{*}{ 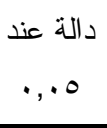 } & \multirow{2}{*}{$\cdot, \cdots$} & \multirow{2}{*}{$T \varepsilon, Y Y \varepsilon$} & \multirow[t]{2}{*}{$0 \wedge$} & $\cdot, 779$ & $1,9 \vee$ & \multirow{2}{*}{9} & الضابطة & التحليل \\
\hline & & & & $\cdot, \leqslant 9$. & $0,7 \pi$ & & التجرييية & البصري \\
\hline \multirow{2}{*}{ 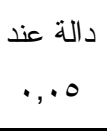 } & \multirow{2}{*}{$\cdot, \cdots$} & \multirow{2}{*}{$0 \cdot, r \cdot V$} & \multirow[t]{2}{*}{01} & $1,9 \cdot 1$ & 19,1 & \multirow{2}{*}{71} & الضابطة & المقياس \\
\hline & & & & r, ro & $\leq 7, \wedge$ & & التجريبية & الكلي \\
\hline
\end{tabular}

متوسط درجات المجموعة التجريبية (Y, (Y)

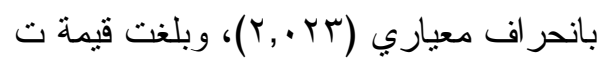

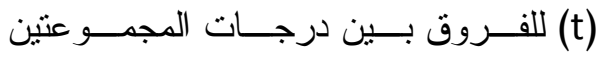

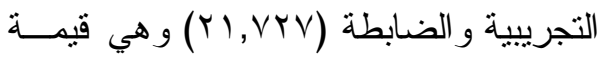
دالة احصائيا عند مـسنتوى دلالـــة (0., .•)،

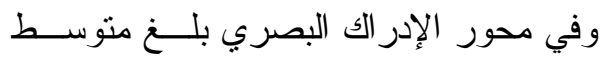

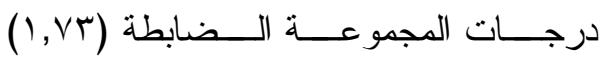

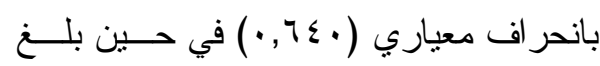

يتضح من الجــدول الــسابق وجــود فروق بين منوسطات درجات المجمـــوعتين

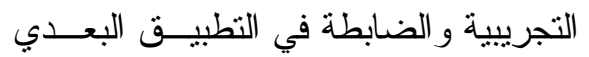

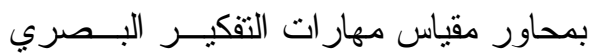
وبالمقياس الكلي لصالح المجموعة التجريبية،

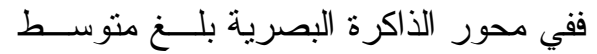
درجــات المجموعــــة الـــضابطة (r, II)

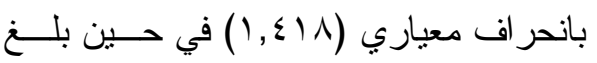




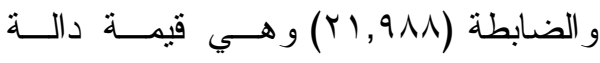

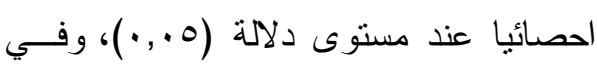
محور التحليل البصري بلغ متوسط درجــات

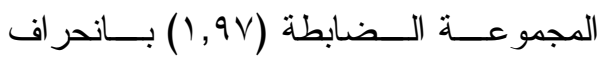

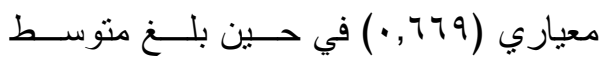

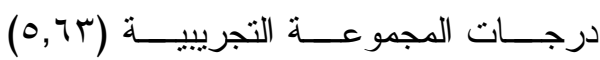
بانحر اف معياري ( • 9 ـ • )، وبلغت قيمة ت

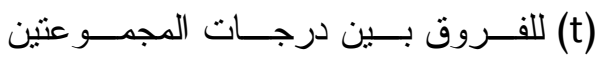

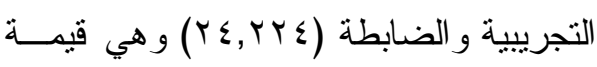
دالة احصائيا عند مسـستوى دلالـــة (0. . •)، وفي مقياس التفكير البــصري الكلــي بلـــن منوسط درجات المجموعة الضابطة (9,1 (1)

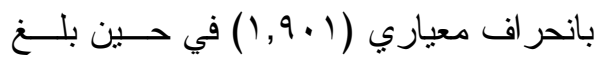

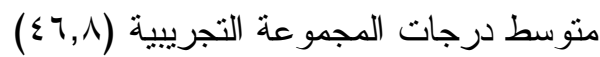

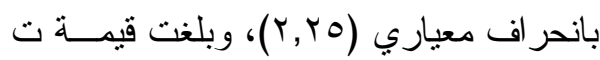

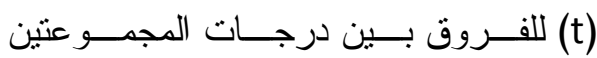

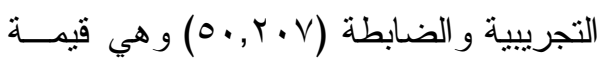

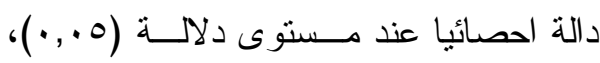
وحيث إن الدلالة المحسوبة تساوي (· (., •) و هي أقل من (0., (·) في جميسع محسـاور المقياس وفي المقياس الكلي، مما يعني وجود فروق دالة احصائيا بين متوسطات درجـات المجمو عتين التجريبية و الضابطة في التطبيق

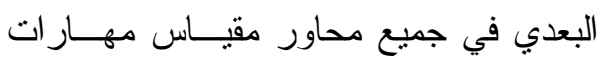
التفكير البصري وفي المقياس الكلي لــصالح

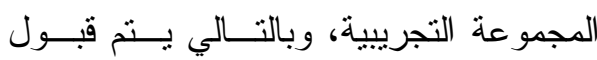

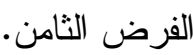

متوسط درجات المجموعة التجريبية (0,0V) بانحر اف معياري (1)071, •)، وبلغت قيمة ت درات

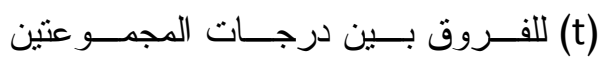

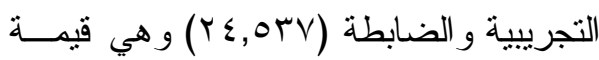
دالة احصائيا عند مسستوى دلالـــة (0., .•)،

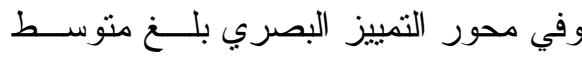

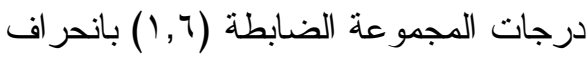

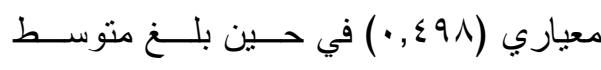

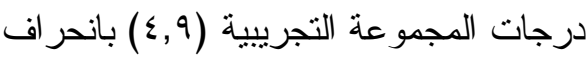

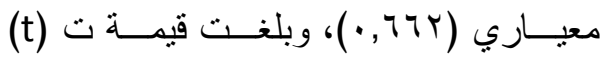
للفروق بين درجات المجموعتين التجريبيـــة

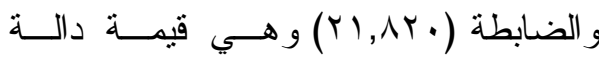
احصائيا عند مستوى دلالة (0., •))، وفـي ولي محور الاتصال البصري بلغ منوسط درجات

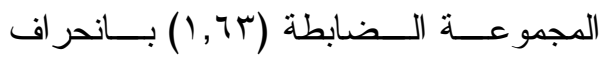

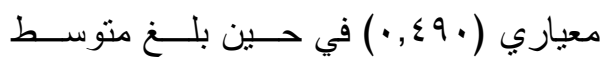
درجات المجموعة التجريبية (9, ؛ ) بانحر اف لاف

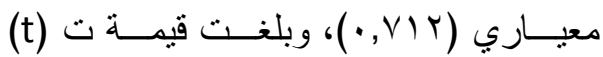
للفروق بين درجات المجمو عتين التجريبيـــة

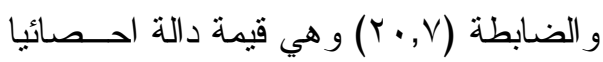
عند مستوى دلالة (0.,.))، وفـي محسـور

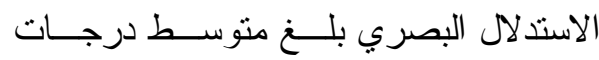

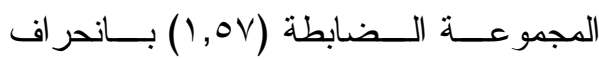

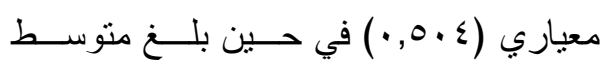

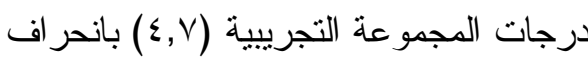

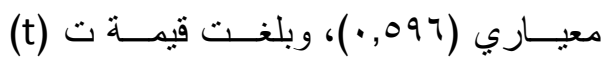
للفروق بين درجات المجموعتين التجرييــــة ولئ 
العروض المصورة ومحاكاة أكثر من بعـــ

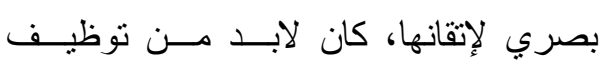

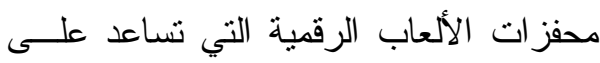

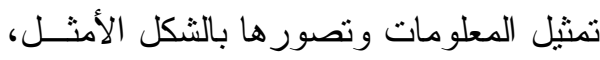
ويتفق ذلك مع نتيجة در اسة كل مــن بليــر

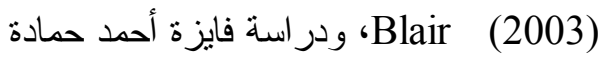

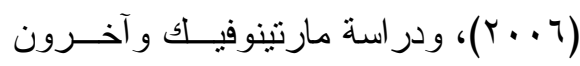
Martinovic et al., (2013) مارشفر انسيــسكو وبر انجيــر - Marache ‘Francisco \& Brangier (2013)

$$
\text { ودر اسة دعاء محمد سيد (10 (r) م). }
$$

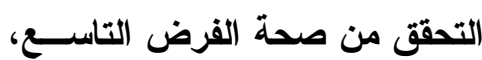

و الذي نصده: "يوجد أثز إيجـابي لاســـتخدام

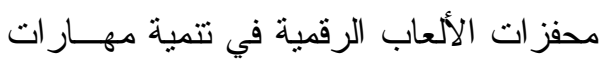

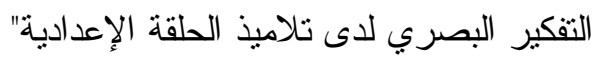
قام الباحث بحساب مربع ايتا وحساب حجم الأثز لاستخدام محفزات الألعاب الرقمية في تتمية مهار ات التفكير البصري لاتئري

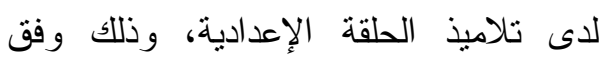

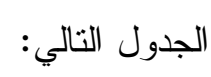

ويفسر الباحث ذللك بأن الفــرق بــين

مجمو عني البحث التجرييية و الضابطة يرجع بان

إلى نمط النشاط المقدم، حيث تعتمد محفزات

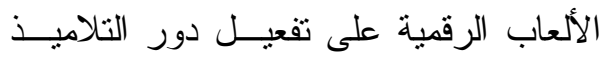
و إبراز التنافس فيما بينهم وتحديد الفائز فــي

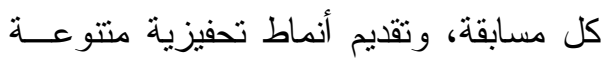
معتمد على مجموعة من الصور و الأشكال، وتحتاج مهارات التفكير البصري إلى المزيد من التفاعلية ويتم ذلك مــن خــلال الأمتلــــة المقدمة من خلال محفز ات الألعاب الرقميــة

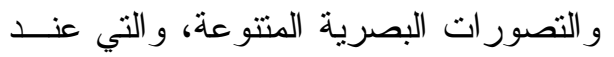
ربطها بالجو انب المعرفية و الأدائية لمهار وات اتهي

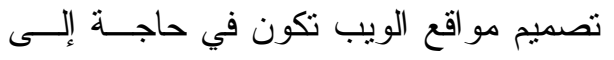

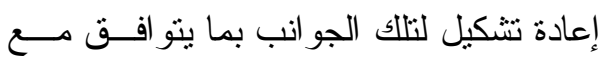

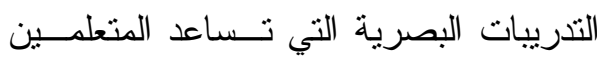
على التفكير بشكل بصري مصور محسوس ليهربه لئس

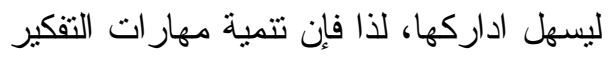

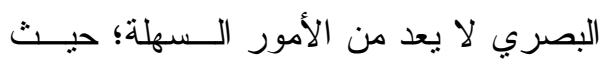

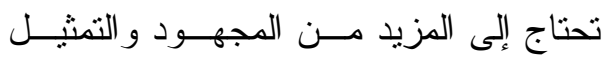
البصري لإتقانها و إمكانية توظيفها بشكل جيد

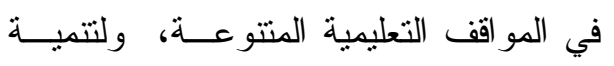

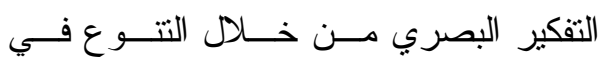




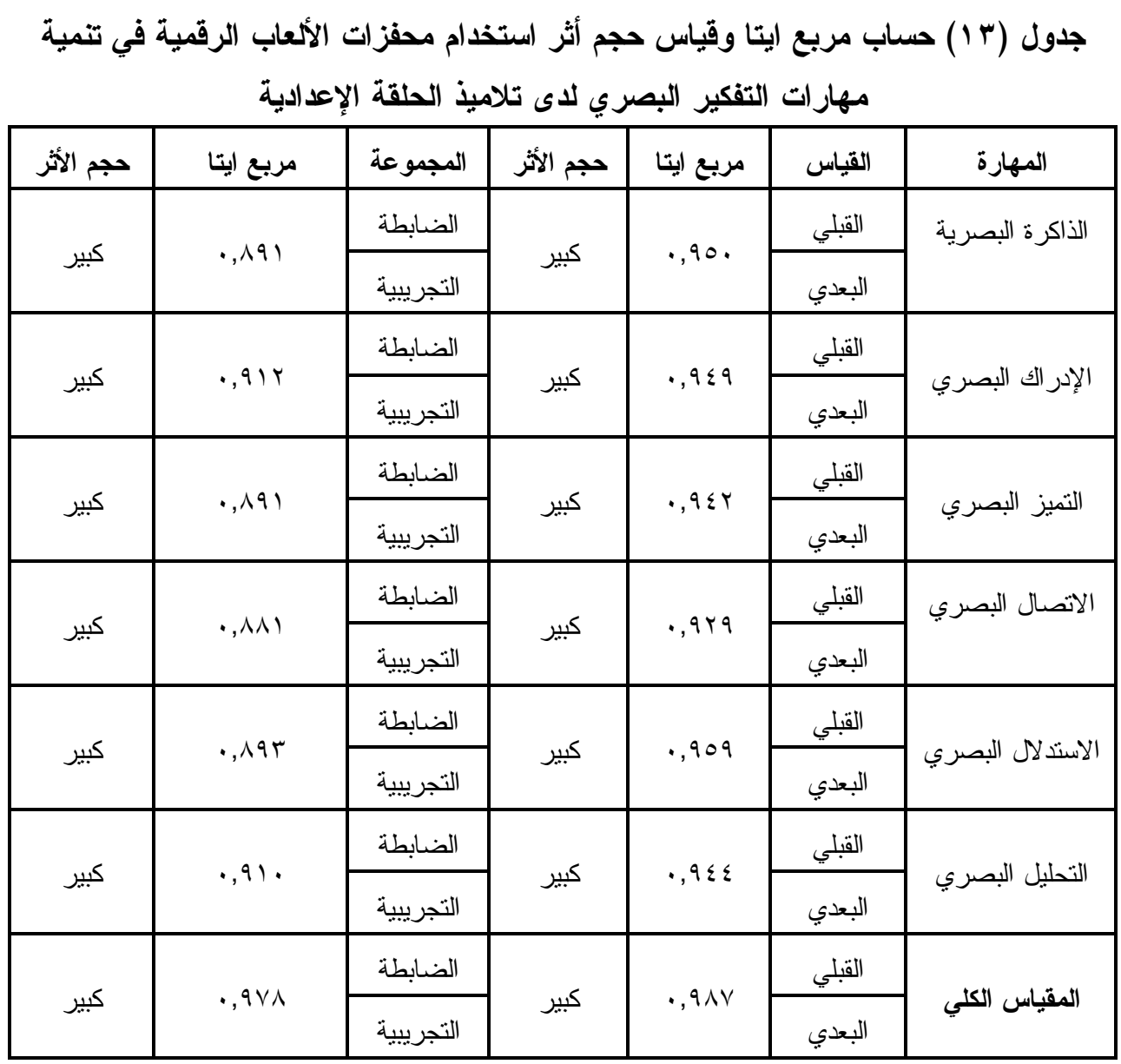

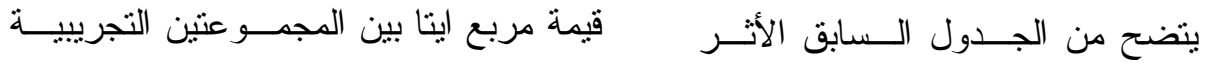

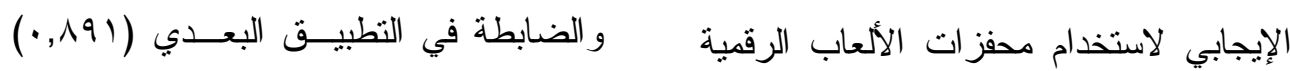

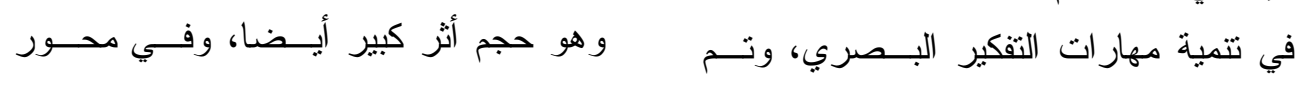

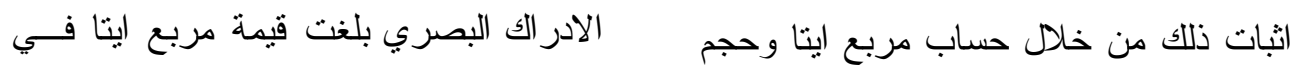

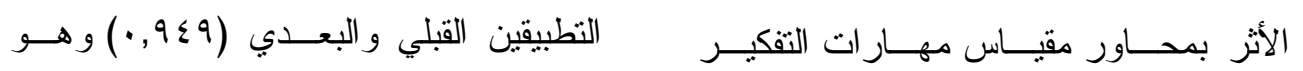

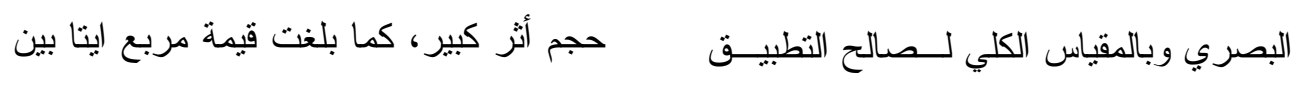

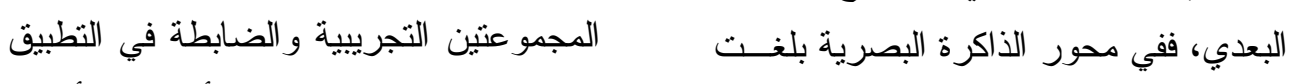

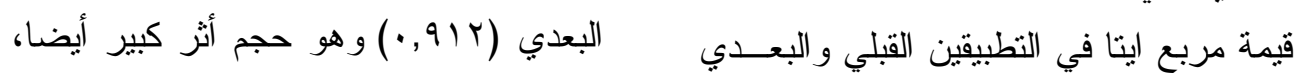

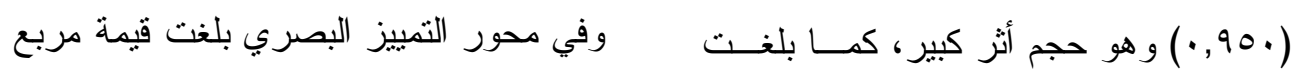


الأثر كبير في جميع محاور مقياس مهار ات

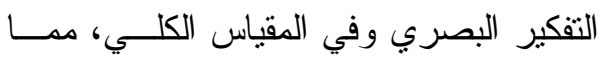
بعني أنه يوجد أثز إيجابي لاستخدام محفزات

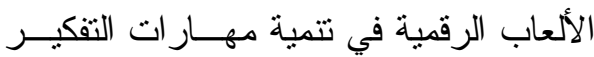

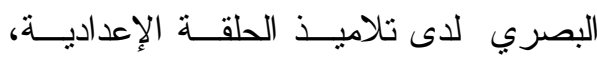
وبالنالي قبول الفرض التاسع. ويفسر الباحث ذلـــك بــأن محفــز ات

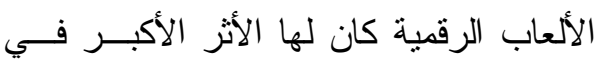
تتمية مهار ات التقكير البصري، وذللك لكـلـل

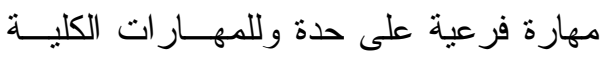
أيضا، حيث إنها تعتمد علــى تفعيـلـ دور

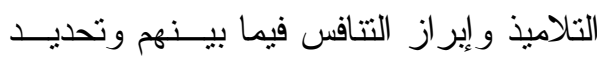
الفائز في كل مسابقة وتقديم أنماط تحفيزيـــة

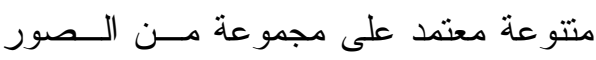
والأشكال، وبما أن مهار ات التفكير البصري معندي تحتاج إلى المزيد من التفاعلية فإن ذلك يــتم

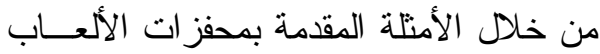

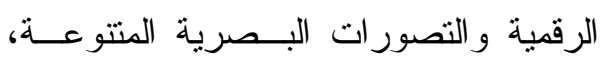

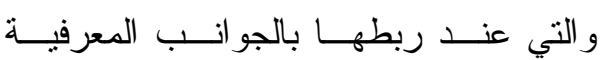
والأدائية لمهار ات تصميم مو اقع الويب تكون

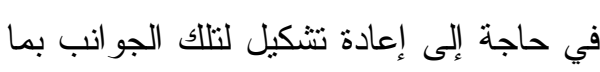
يتو افق مع التدريبات البصرية التي تـساعد إعادة تنكي

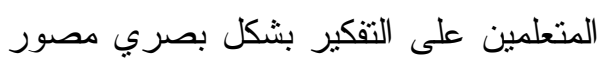

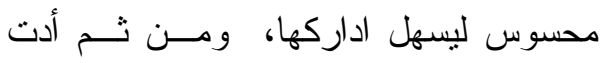
محفز ات الألعاب الرقمية إلى لتتمية التفكيــر

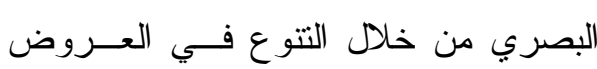

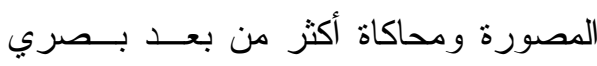

ايتا في التطبيقين القبلي و البعـدي (r؟ 9, •) وهو حجم أثر كبير ، كما بلغت قيمة مربــع ولنع

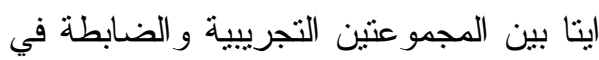

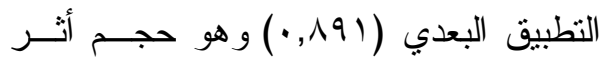

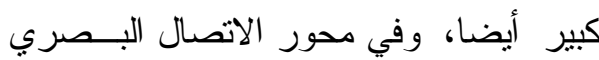

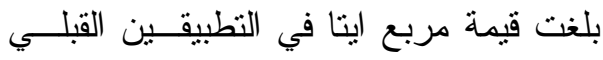
و البعدي (9 9 9, •) وهو حجم أثز كبير، كما

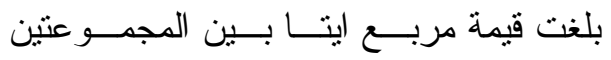

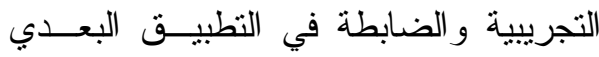

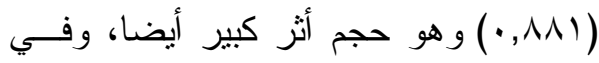

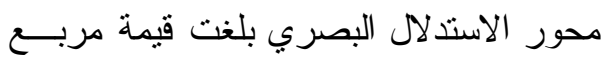
ايتا في التطبيقين القبلي و البعـدي (909, • •)

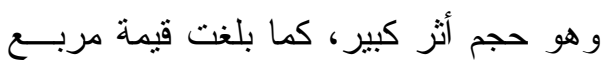
ايتا بين المجموعتين التجريبية و الضابطة في

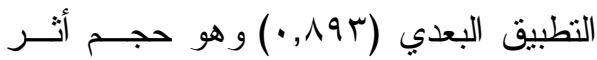

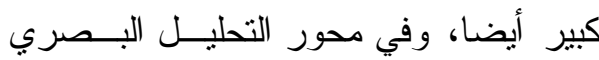
بلغت قيمة مربع ايتا في التطبيةــين القبالــي و البعدي (؟ 9 9, •) وهو حجم أثر كبير ، كما

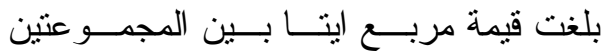

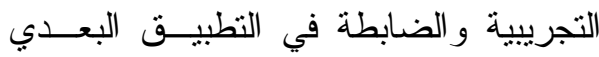

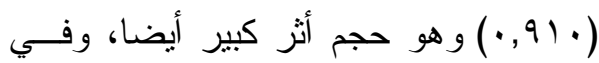
مقياس التفكير البصري الكلي بلغـــت قيمــة

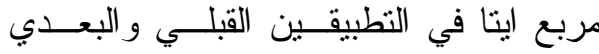
(9NV)

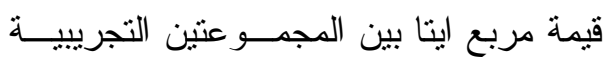

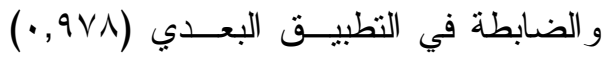
وهو حجم أثر كبير أيضا، وحيث إن حجـ 
ـ. إعداد معلمي الحلقة الإعدادية للتعامـلـل مع الأســاليب الحديثــة فــي التعلــيم وتطبيقها مع تناميذهم.

○. نشر ثقافة محفز ات الألعــاب الرقميــة وتوظيفها في التعلم بــالمو اد الدر اســية الدية المختلفة.

7. دعوة خبر اء في مجال التعلم الإككتروني

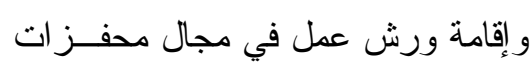

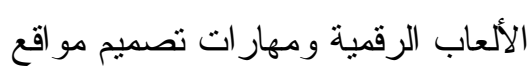
الويب لتلاميذ الحلقة الإعدادية. ثانياً_مقتزحات البحث: فى ضوء نتائج البحـــث وتوصــياته تتضح الحاجة إلى القيام بالبحوث و الدر اسات التالية:

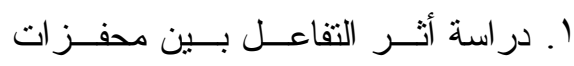

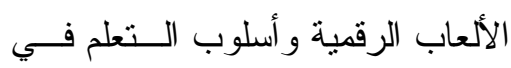
تتمية مهار ات تصميم مو اقع الويب لدى تلاميذ الحلقة الإعدادية. Y. دراسة أثر تتوع أساليب تقديم محفزات

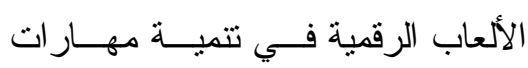
تصميم مواقع الويب.

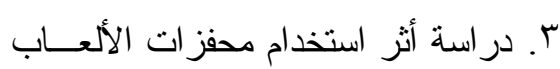
الرقمية في تتمية مهار ات التفكير العليا لدى طلاب المرحلة الثانوية. ع. در اسة اتجاهات تلاميذ الحلقة الإعدادية نحو استخدام محفز ات الألعاب الرقمية.

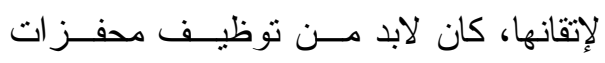

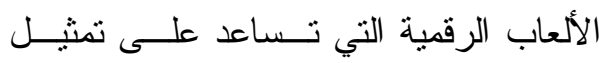
المعلومات وتصور ها بالثكل الأمنل، ويتفق ذللك مع نتيجة در اسة كل من بليـر

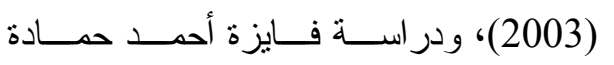

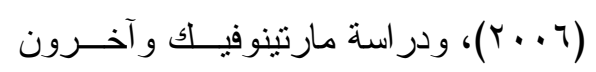

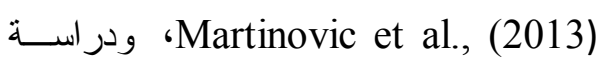
مارشفر انسيــسكو وبر انجيــر - Marache ‘Francisco \& Brangier (2013)

$$
\text { ودر اسة دعاء محمد سيد (10 ( ب). }
$$
التوصيات والمتزحات:

في ضو ء ما سبق يتتـــاول الباحـــث

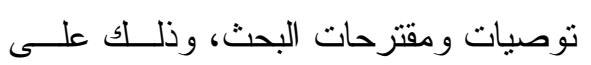
النحو التالي: - التيات أولأتوصيات البحث:

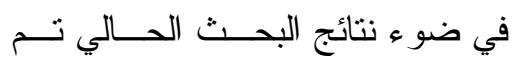
التوصل إلى بعض التوصيات يمكن صباغتها كالتالى:

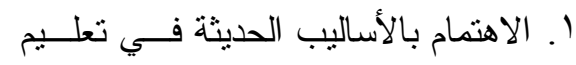

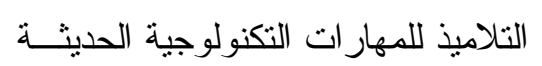
التي تساعدهم على الابتكار .

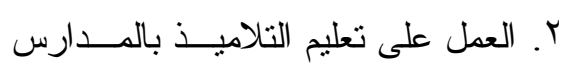

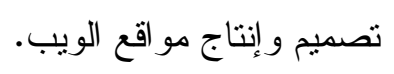
r. ضرورة الاهتمام بأساليب تعلم التلاميذ

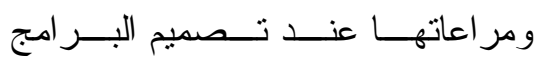
التعليمية. 


\begin{tabular}{|c|c|}
\hline 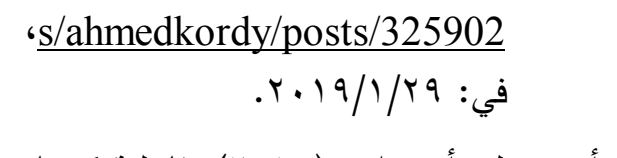 & •. در اسة أثز استخدام محفز ات الألعـــاب \\
\hline أحمد علي أبو زايدة (10 • ب). فاعلية كتــاب & تلاميذ الحلقة الإعدادية. \\
\hline تفاعلي محوسب في تتميــة مهـــار ات & 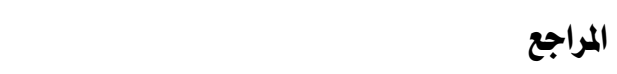 \\
\hline التفكير البصري في التكنولوجيا لــدى & 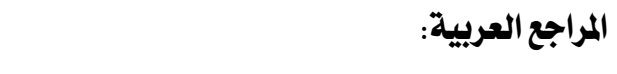 \\
\hline صلاب الصف الخــامس الأساســـي & أحمد زارع أحمد (ع ا • r). فاعلية اســتخدام \\
\hline بغزة. رسالة ماجستير ـ كلية التربيـــة. & الألعاب الذكية التفاعلية في الجغرافيا \\
\hline الجامعة الإسلامية بغزة. & فـــي تتميــــة المفـــــيم الاقتــــــادية \\
\hline أحمد عــودة القرارعــة (9 . . ب). تــصميج & ومهار ات التفكيــر البــصري لـــى \\
\hline التدريس رؤية تطبيقية. عمــان: دار & التتلاميذ الموهـــوبين ذوي صـــوبات \\
\hline 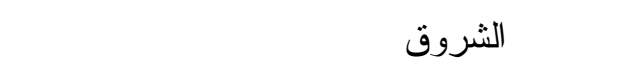 & الــتـعلم. مجلـــة الجمعيـــة التربويـــة \\
\hline استر اتيجية التتمية المستدامة. رؤية مـصر & للار/سات الاجتماعية. كلية التربيــة. \\
\hline • • r.، محور التعلـيم و التــدريب. & جامعة عـين شــمس. ( • T). بسا - \\
\hline 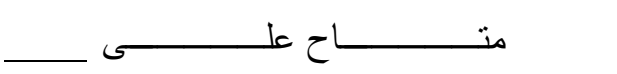 &.$I V Y$ \\
\hline$\frac{\text { http://sdsegypt2030.com/\%d }}{8 \% \mathrm{a} 7 \% \mathrm{~d} 9 \% 84 \% \mathrm{~d} 8 \% \mathrm{a} 8 \% \mathrm{~d} 8}$ & 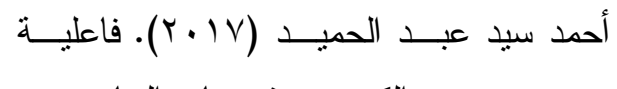 \\
\hline$\frac{\% \mathrm{~b} 9 \% \mathrm{~d} 8 \% \mathrm{af}-}{2}$ & محتوى إلكتروني في مادة الحاســـوب \\
\hline \%d8\%a7\%d9\%84\%d8\%a7\% & قائم على استر اتيجية الألعاب التتافسية \\
\hline$\frac{\mathrm{d} 8 \% \mathrm{ac} \% \mathrm{~d} 8 \% \mathrm{aa} \% \mathrm{~d} 9 \% 85 \% \mathrm{~d} 8}{\% \mathrm{a} 7 \% \mathrm{~d} 8 \% \mathrm{~b} \% \% \mathrm{~d} 9 \% 8 \mathrm{a} / \% \mathrm{~d} 8}$ & الرقمية في تتمية التحــصيل وكفـــاءة \\
\hline$\% \overline{\mathrm{a} 7 \% \mathrm{~d} 9 \% 84 \% \mathrm{~d} 8 \% \mathrm{aa} \% \mathrm{~d} 8 \%}$ & التعلم لدى تلاميذ المرحلة المتوســـة \\
\hline b9\%d9\%84\%d9\%8a\%d9\%85 & بالمملكة العربية الـسعودية. رســالة \\
\hline 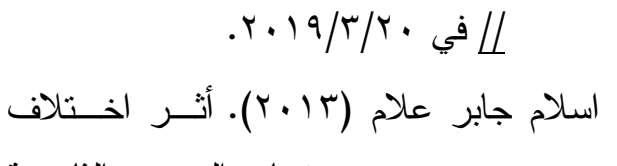 & ماجستير ـ كلية الدر اسـات التربويــة. \\
\hline تــــميم صـــــات الويـــب الثابتـــة & 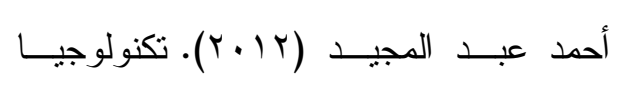 \\
\hline 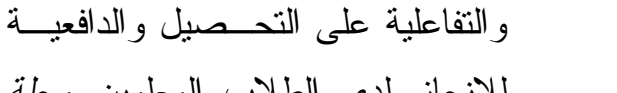 & المعلومات و التفكير البصري. كنانــة \\
\hline 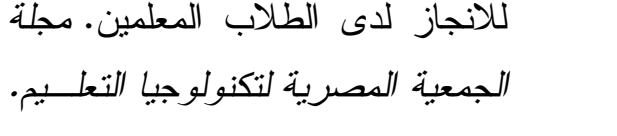 & 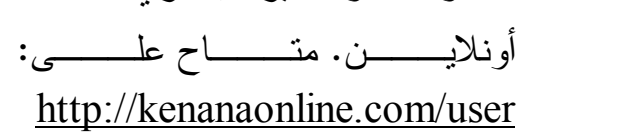 \\
\hline $.1 \leq 9-99 .(r r))$ & \\
\hline
\end{tabular}


المعلومات الدولية. رسالة ماجسستير. كلية التزبية. جامعة حلو ان.

تامر المغاوري الملاح، ونور الهدى محمـــ

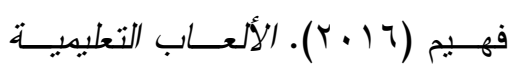

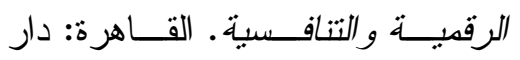

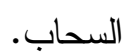

تسبيح أحمد فتحي (Y V V V). تصميم بيئة تعلم

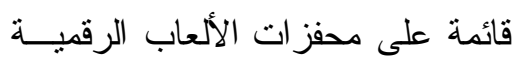

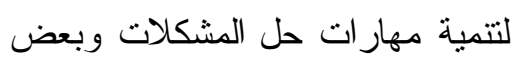

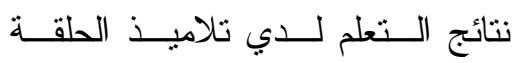
الابتدائية. رســالة ماجـستير ـ كليـــة

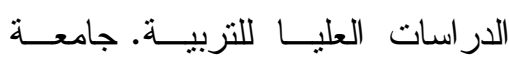

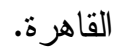

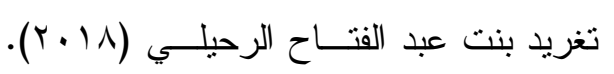

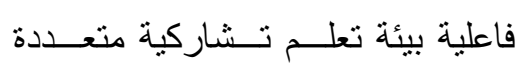
الوسائط قائمة على التلعيب في تتمية

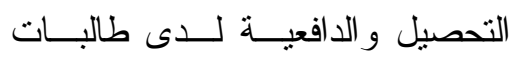
جامعة طيبة. مجلة الجامعة الاسلامية

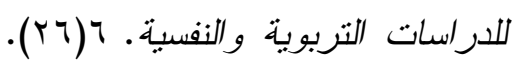
.Ar-or حسن البــاتع محمـــ (• ( • ب). التـصديم

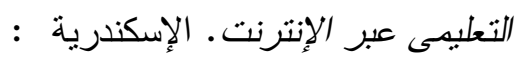
دار الجامعة الجديدة.

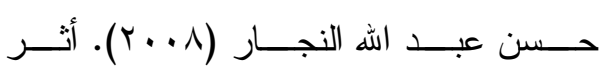
استر اتيجية التعلم التوليفي في تتميــة مهار ات تصميم مو اقع الويب التعليمية
إسلام زياد منصور (10 • r). فاعلية برنامج

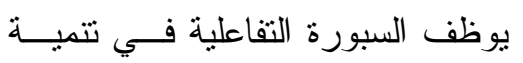
مفاهيم ومهارات التفكيــر البـصري

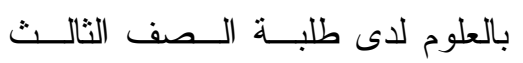
الأساسي. رســالة ماجـستير ـ كليــة التزبية. الجامعة الإسلامية بغزة.

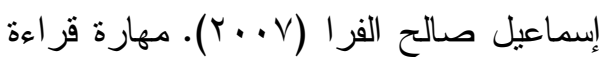
الصور لدى الأطفال بوصفها وســيلة

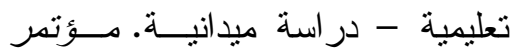
ثقافة الصورة، المنعقد بتــاريخ گrك-

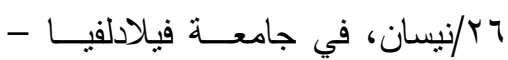

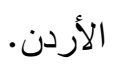
أكرم فتحي مصطفى (ع . . ب). إنتاج مواقـع

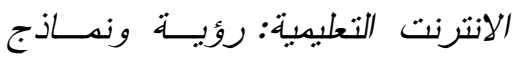
تعليمية معاصرة في التعلم عبر مواقع روني الانترنت. القاهرة: عالم الكتب.

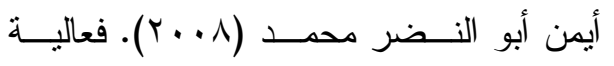
استخدام برنامج التعليم عن بعد فـي

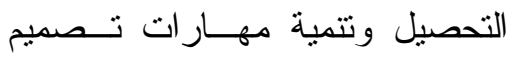
موقع الكتروني لدى تلاميــــ الحلقـــة

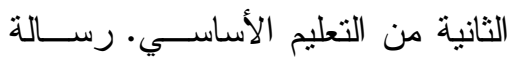

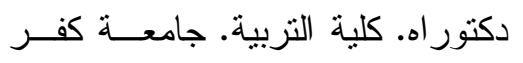
الثيخ.

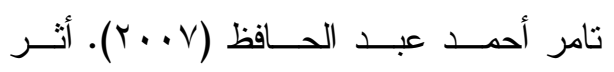
اختلاف نمطي التعلم التعاوني علـى تصميم و اجهة تفاعل صــفحة شــبكة 


$$
\begin{aligned}
& \text { لاى طــلاب التكنولوجيــا بجامعـة دعاء محمد سيد عبد الرحيم (10 • ب). فعالية } \\
& \text { استخدام الألعاب التعليمية الإلكترونية } \\
& \text { الأقصى و اتجاههم نحسـوه. الجمعيــة } \\
& \text { في تدريس الدراســات الاجتماعيــة } \\
& \text { لتلاميذ الصف الخامس الابتدائي بينبع }
\end{aligned}
$$

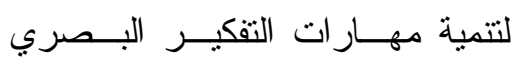

$$
\begin{aligned}
& \text { المكاني. مستقبل التربيــة العربيــة. } \\
& \text { المركز العربــي للتعلــيم و التتميــة. }
\end{aligned}
$$

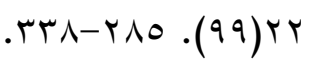

$$
\begin{aligned}
& \text { رقية عبيد العتيبي (1/ (Y). درجة تطبيـق } \\
& \text { إستر اتيجية التلعيب ومعوقات تطبيقها } \\
& \text { لدى معلمات الحاسب الآلي بمنطقــة } \\
& \text { الرياض بالمملكة العربية الـسعودية. } \\
& \text { مجلة كلية التربية. جامعة أسيوط. ع } \\
& .0 . \varepsilon-\varepsilon V) .(r \varepsilon)
\end{aligned}
$$

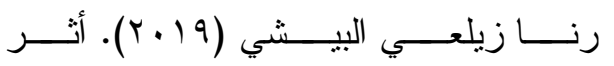

$$
\begin{aligned}
& \text { الانفوجر افيك التفــاعلي فـــي تتميـــة }
\end{aligned}
$$

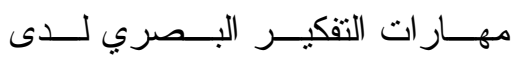

$$
\begin{aligned}
& \text { المشرفات التربويات في مدينة تبوك. } \\
& \text { مجلة القراعة و المعرفة . كلية التزبية. }
\end{aligned}
$$

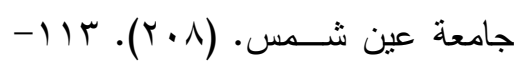

$$
\begin{aligned}
& \text {.1 } \leqslant \text {. } \\
& \text { زكريا جـابر حنــاوي (9 (ب). الألعــاب }
\end{aligned}
$$

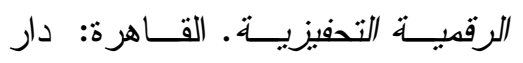

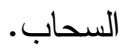

$$
\begin{aligned}
& \text { زكريا جابر حناوي وماريان ميلاد منــصور }
\end{aligned}
$$

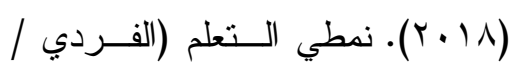

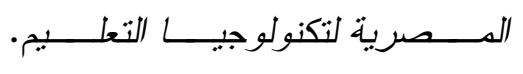

$$
\begin{aligned}
& .1 \vee \leqslant-1 \leqslant r .(1 \Lambda) r \\
& \text { حسن ربحي مهدي (T + . ץ). فاعلية استخدام } \\
& \text { برمجيــات تعليميـــة علـــى التفكيــر } \\
& \text { البصري و التحصيل فــي تكنولوجيــا }
\end{aligned}
$$

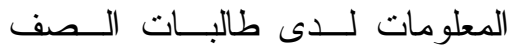

$$
\begin{aligned}
& \text { الحادي عثر • رسالة ماجستير • كليــة } \\
& \text { التزبية. الجامعة الإسلامية بغزة. } \\
& \text { حنان عبد السلام عمـر (10 • ب). اســتخدام } \\
& \text { الخرائط الذهنية الرقمية في تــدريس }
\end{aligned}
$$

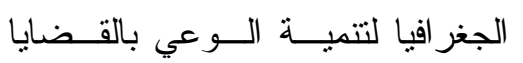

$$
\begin{aligned}
& \text { البيئية ومهار ات التفكير البصري لدى لئ لادي }
\end{aligned}
$$

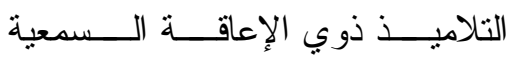

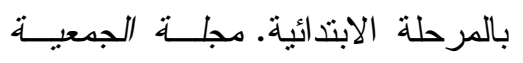

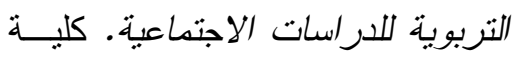

$$
\begin{aligned}
& \text { التربية- جامعة عين شـمس. ( ع V). } \\
& \text {. Tा } 2-191
\end{aligned}
$$

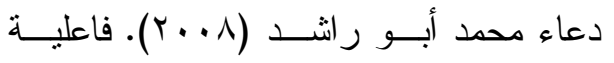

$$
\begin{aligned}
& \text { برنامج مقترح متعدد الوسائط لتتميــة }
\end{aligned}
$$

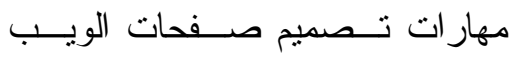

$$
\begin{aligned}
& \text { التعليمية لدى طلاب قـسم الحاســبـ } \\
& \text { الالي قسم اعداد معلم الحاسب الالي. } \\
& \text { رسالة ماجسنير. كلية النزبية النوعية } \\
& \text { بدمياط. جامعة المنصورة. }
\end{aligned}
$$


دكتور اة. كلية التزبية. جامعة عـين شمس.

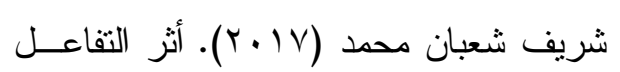
بين عناصر محفز ات الألعاب الرقمية والأسلوب المعرفي في تتمية مهارت

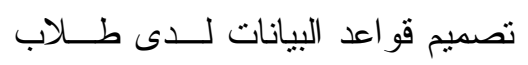
المعاهد العليا. مجلة دراسات عربيـة

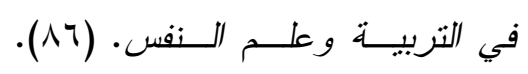
. $\varepsilon . \varepsilon-r \leqslant \vee$

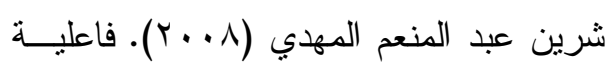

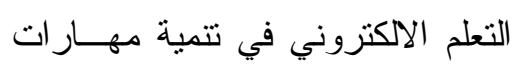
تصميم صفحات الانترنت التعليميــة

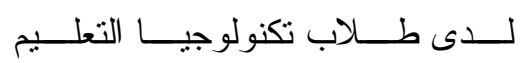
و اتجاهاتهم نحوه. رسالة ماجستنير. كلية التربية. جامعة كفر الثيخ.

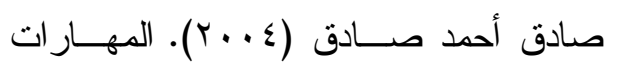
الأساسية للتصميم. الجزء الثالث: بناء وصقل مهار ات المجال النفس-حركي و المهار وات البصرية. مجلة الإمارات

$$
\text { للبحوث الهندسية. } 9 \text { (1). }
$$

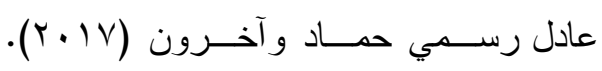

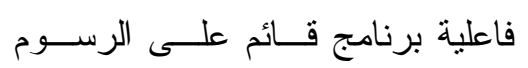
المتحركة في تدريس التاريخ لتتميــة

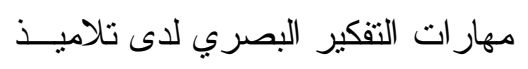

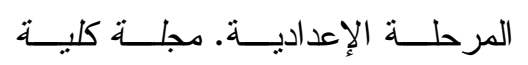

التشاركي) باستخدام الألعاب الرقميــة

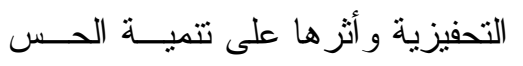
الكسري و المهار ات التكنولوجية لدى ولئ

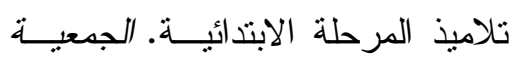
العربية لتكنولوجيــا التربيــة. (rv). . $\varepsilon \cdot V-r \leqslant 1$

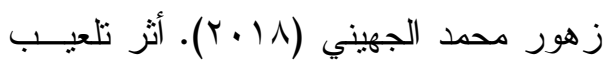

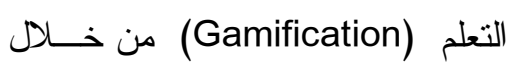

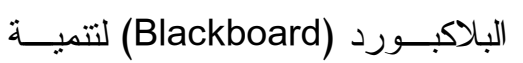
مهار ات حل المشكلة في الرياضـــيات

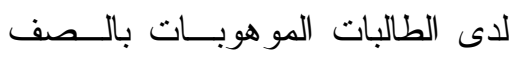
الأول ثانوي. مجلة البحث العلدي في التربية . جامعة عين شمس. 9 (1) (1). $.19-11$

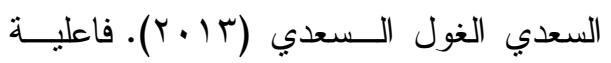
الألعاب الرقمية في تــدريس وحــدة دورية العناصر وخو اصها في تتميــة

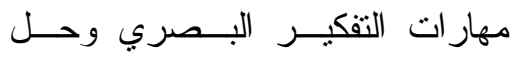

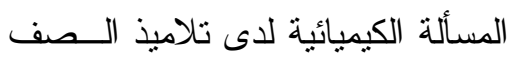

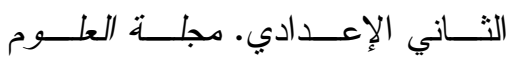

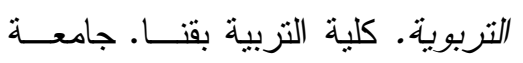

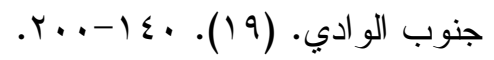

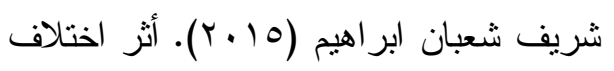

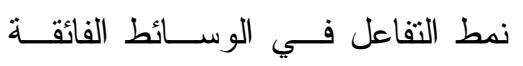

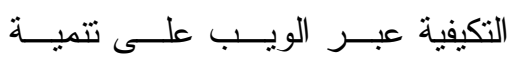

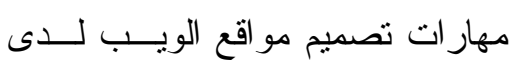

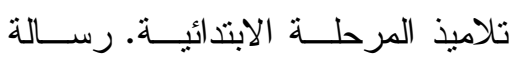


التربويـــة. كليـــة التربيـــة. جامعـــة

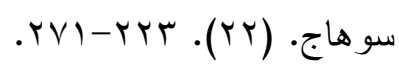

فتحي مصطفى الزيــات (997 (1)). الأسـس البيولوجية والنفسية للنـشاط العقلــي العي

الدعرفي: المعرفة والذاكرة الابنكار .

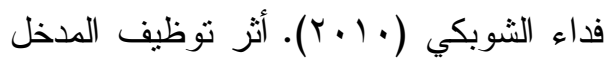

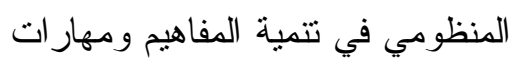
التفكير البصري بالفيزياء لدى طالبات الــصف الحــادي عـشر · رســالة

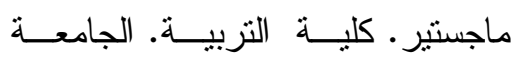
الإسلامية. غزة

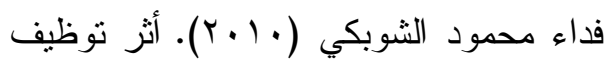
المدخل المنظومي في تتمية المفـــاهيم ومهار ات التفكير البصري بالفيزيــاء لدى طالبات الصف الحــادي عـشر . رســالة ماجسـتير ـ كليــة التربيــة. الجامعة الإسلامية بغزة.

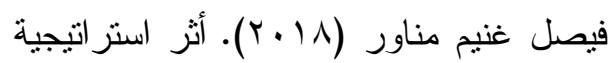

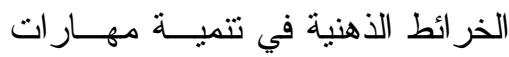
التفكير البصري بمقرر الرياضــيات لدى طلاب الصف السادس الابتدائي. المؤتتر العلدـي الــسنوي الــسادس عشر: تطوير تعليم وتعلم الرياضيات لتحقيـق ثقافـــة الجــودة. الجمعيـــة المصرية لتزبويات الرياضيات. كلية التربية. جامعة بنها. 110
التربية- جامعــة أســيوط. سم(r). $.19 .-17 r$

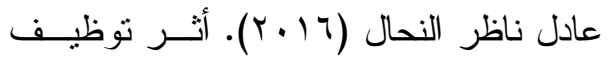

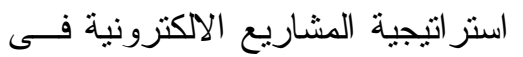

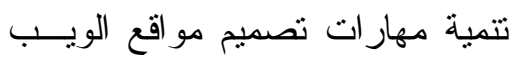

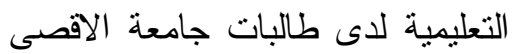
بغزة. رسالة ماجسنتر . كلية التلابية. الجامعة الاسلامية-غزة.

عائشة بلهيش العمــري وأميمـــه محفــوظ

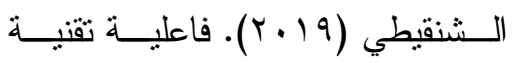
التلعيب في بيئة الـتـعلم الالكترونيــة لتتمية مهار ات انتاج المواد الرقميــة

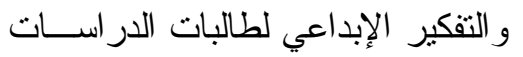
العليا. مجلـــة الجامعـــة الاســلامية

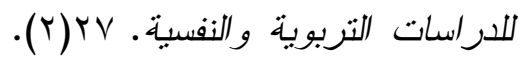
$.771-749$

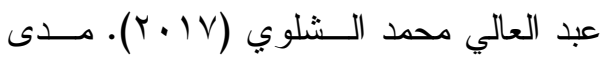
تو افر مهار ات التفكير البصري فـي

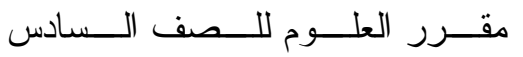

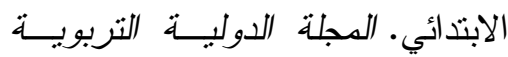

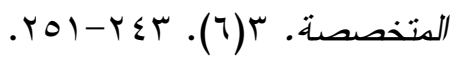
فايزة أحمد محمد حمادة (T . . ץ). اســتخدام

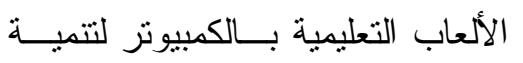

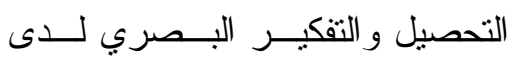

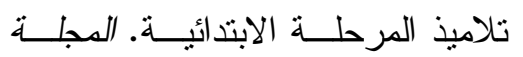


الافتز اضية في تتمية مهار ات تصميم

مو اقع الانترنت لتلاميذ الحلقة الثانيـــة

من التعليم الأساسي. رسالة ماجستير. كلية التربية. جامعة كفر الثيخ.

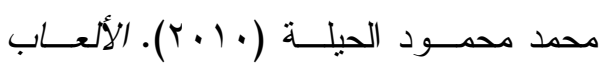
التربوية وتقنيات إنتاجها: سيكولوجيا وتعليميا وعمليا. عمان: دار المسيرة.

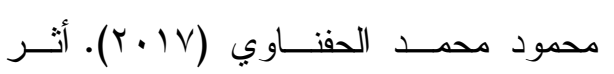
استخدام الأنشطة الإلكترونية المبنيـــة

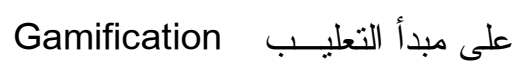
في ضوء المعايير لتنميــة المفــاهيم

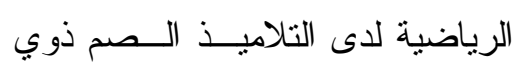

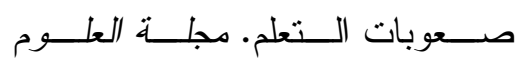

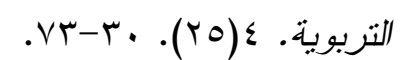

مديحة حسن محمد (ع . . r). تتمية التفكيـر

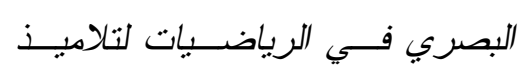
المرحلة الابتدئية (الصم -العاديين). القاهرة: عالم الكتب.

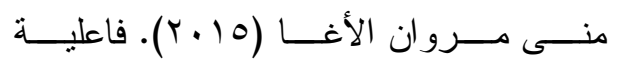
تكنولوجيا الواقع الافتر اضي في تتمية

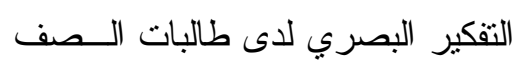

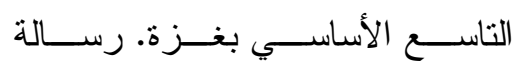

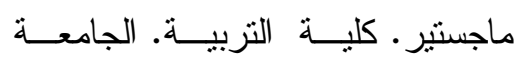
الإسلامية بغزة.

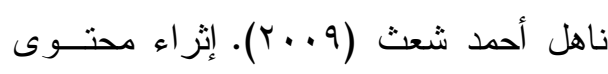

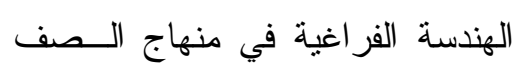

كمال عبد الحميد زيتون (ع ... ب). التدريس

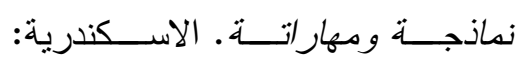
المكتب العلمى للنشر و التوزيع. محمد عبد المنعم شحاته (ع ( ا ب). برنــامج

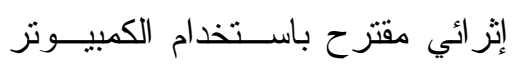

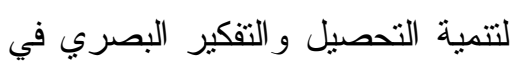

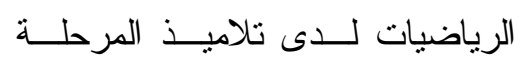

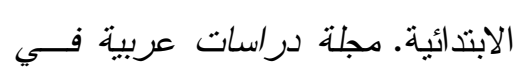

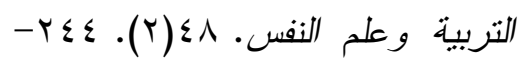
. Y人T محمد عبده الحايس (r ( ب). فاعلية إستخدام استر اتيجية تقصي الويب فــي تتميــة

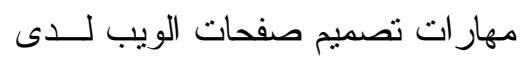

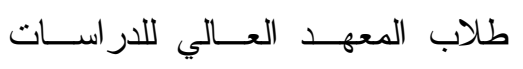
النوعية. مجلة التربية. كلية التربيـــة.

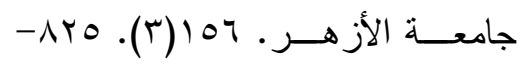
.

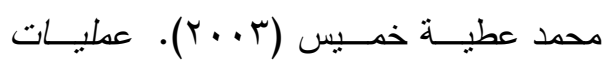

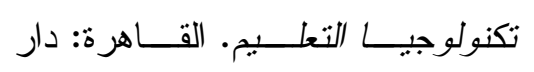
الكلمة. محمد عيد عمار ، ونجــوان حامـــد القبــاني

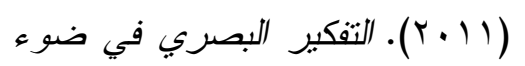
تكنولوجيا التعليج. الاسـكندرية: دار الجامعة الجديدة.

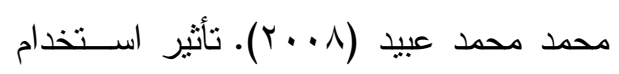
التعليم بمساعدة الكمبيونز و الفــصول 


$$
\begin{aligned}
& \text { وليم عبيد وعزو عفانــة (ب... (Y). التفكيـر }
\end{aligned}
$$

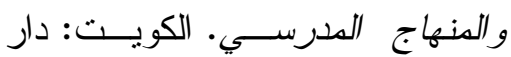

$$
\begin{aligned}
& \text { الفلاح للنشر و التوزيع. } \\
& \text { اليونسكو (10 • (Y). مستقبل التعلم r: مانوع }
\end{aligned}
$$

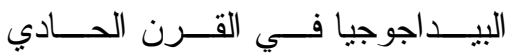

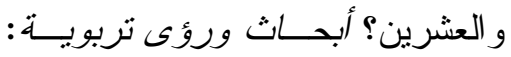

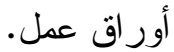$$
\text { المراجع الأجنيية: - اونية }
$$

Alexandru, I., \& Dick, E., (2014).

An experience report on using gamification in technical higher education. $45^{\text {th }}$ ACM technical symposium on computer science education. 27-32. Retrieved from: http://dl.acm.org/citation.cfm ?id=2538899. On: $2 / 1 / 2019$.

Blair, R., (2003). The Effects of story Webbing and Visual Thinking Software on the written Language Performance of students with Mild Disabilities, PhD Dissertation, University of Oklahoma.

Caponetto, I., Earp, J., \& Ott, M., (2014). Gamification and education: A literature review. In European Conference on Games Based Learning. Conferences (1). Academic Limited.
العاثر الأساسي بمهـــار ات التفكيــر

البصري. رســالة ماجسـتير • كليــة

التربية. الجامعة الإسلامية-غزة.

نبيل جاد عزمي و آخرون (V ا • Y). تطبيقات و أدوات الألعاب التتافسية الرقمية فى التعليم. المؤتدر العلدي الدولي الأول - التربية النوعيــة وجـــودة العدــل المجتمعي "رؤية مسستحدثة". كلبــة

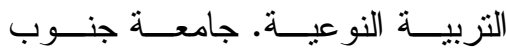

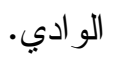

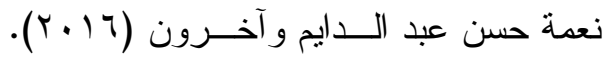

إعداد كتاب إلكتروني لتتمية مهارات التفكير البصري و الوعي البيئي لــدى أطفال الروضة. مجلة البحــوث فـي لئي

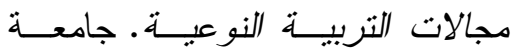
المنيا. (v). (

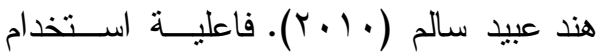
الحاسوب في تتمية مهار ات التفكيـر البصري و الاتجاه نحـــو الرياضــيات لدى طالبات الصف التاسع الأساسي. رسالة ماجسستير ·جامعــة مؤتـــة.

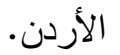

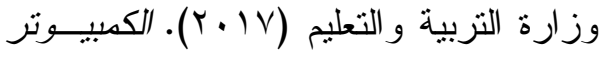
وتكنولوجيا المعلومات و الاتــصالات. جمهورية مصر العربية. 
Technology. (27). Retrieved from:

https://journal.alt.ac.uk/index .php/rlt/article/view/2093/24 68\#toc. On: 7/5/2019.

Enders, B., (2013). gamification, games, and learning: what managers and practitioners need to know. Retrieved from:

https://dharmamonk.files.wor dpress.com/2014/01/guildres earch_gamification2013.pdf. On: $2 / 1 / 2019$.

Eppler, M., \& Pfister, R., (2011). Sketching at Work: A Guide to Visual Problem Solving and Communication. MCM Institute. St. Gallen.

Genovesi, J., (2011). An Exploratory Study of a New Educational Method Using Live Animals and Visual Thinking Strategies for Natural Science Teaching in Museums. PhD Dissertation. Drexel University.

Hsin, W., Huang, Y., \& Soman, D., (2013). Gamification of Education: Research Report Series Behavioral Economics in Action. Rotman School of Management University of Toronto.

Hunick, R., Leblanc, M., \& Zubek, R., (2004). MDA: A Formal Approach to Game Design and Game Research. In
Carey, B., (2007). This is your life (and how you tell it). New York Times Online. Retrieved from:

www.nytimes.com/2007/05/2 2/health/psychology/22narr.h tml?em\&ex $=1180065600 \& \mathrm{e}$ $\mathrm{n}=4 \mathrm{~d} 426931 \mathrm{~b} 2330$ fae \&ei $=50$ 87\%0A. on: $10 / 4 / 2019$.

Deci, E., \& Ryan, R., (2001). SelfDetermination Theory, University of Rochester, Rochester, NY, USA. Retrieved from: https://pdfs.semanticscholar. org/0a5f/d9f90632ba0e7be5c bae52813429b05bb7d5.pdf. On: $29 / 4 / 2019$.

Deterding, S., at al., (2011). From game design elements to gamefulness: Defining "gamification". In Proceedings of the 15th International Academic MindTrek Conference: Envisioning Future Media Environments (9-15). New York, NY, USA: ACM.

Domínguez, A., et al., (2013). Gamifying learning experiences: Practical implications and outcomes. Computers \& Education, (63). 380-392.

Doney, I., (2019). Research into effective gamification features to inform e-learning design. Research in Learning 
Kiryakova, G., Angelova, N. \& Yordanova, L., (2014). Gamification in education. Proceedings of 9th International Balkan Education and Science Conference.

Lee, J., Hammer, J., (2011). Gamification in Education: What, How, Why Bother? Academic Exchange Quarterly. 15(2).

Legault, L., (2017). SelfDetermination Theory. Clarkson University, Potsdam, NY, USA. Retrieved from: https://www.researchgate.net /publication/317690916. On: 29/4/2019.

Longo, P., (2001). What Happens to Student Learning When color is Added to A new Knowledge Representation Strategy? Implication from Visual Thinking Network. ERIC. ED.454096.

Marache-Francisco C., \& Brangier E., (2013) Perception of Gamification: Between Graphical Design and Persuasive Design. In: Marcus A. (eds) Design, User Experience, and Usability. Health, Learning, Playing, Cultural, and CrossCultural User Experience. DUXU 2013. Lecture Notes proceedings of the challenges in games AI Workshop, Nineteen National Conference of Artificial Intelligence. San Jose, CA: AAAI Press.

Jackson, L., (2009). Introduction to the internet and web page design. Master thesis. Faculty of Communication. Southern Utah University.

Jackson, L., (2016). Gamification in Education: A Literature Review, professional development program conducted by the center for faculty Excellence. United States Military Academy, West point. NY,

Joomun, N., (2018). 5 steps to achieving successful gamification. Retrieved from: https://knowledgeone.ca/reus sir-votre-ludification-en-5etapes. on: 20-4-2019

Kapp, K., (2012). The gamification of learning and instruction: Game-based methods and strategies for training and education. San Francisco: Wiley.

Kim, J. \& Lee, W., (2013). Dynamical Model and Simulations for Gamification of learning. International Journal of multimedia and Ubiquitous Engineering. 8(4). 179-190. 
Computer Scientists and Information Technologists Conference. 242-251.

Oxford Analytica (2019). Gamification of education: How education can be improved with concepts drawn from video games. Retrieved from: http://www.oxan.com/insight s/clientthought-leadership/archive/g amification-of-education/. On: 20/4/2019.

Paharia, R., (2013) Loyalty 3.0: How to revolutionize customer and employee engagement with big data and gamification. McGrawHill.

Prensky, M., (2001). The Games Generations: How Learners Have Changed. in: Digital Game-Based Learning. McGraw-Hill.

Robson, K., et al. (2015). Is it all a game? Understanding the principles of gamification Asestgetics. Business Horizons. 1216-1226

Ruffini, M., (2000). Systematic Planning in the Design of an Educational Web Site. Educational Technology, 40 (2). 58-64.

Saavedra, A. \& Opfer, V., (2012). Teaching and Learning 21st Century Skills: Lessons from in Computer Science, (8013). Springer, Berlin, Heidelberg

Martinovic, D., at al., (2013). Gamification of Life: Playing Computer Games to Learn, Train, and Improve Cognitively. Journal of Educational and Social Research, 3(8), 83-89.

Melo, A., et al., (2014) Version Control System Gamification: A Proposal to Encourage the Engagement of Developers to Collaborate in Software Projects. In: Meiselwitz G. (eds) Social Computing and Social Media. SCSM 2014. Lecture Notes in Computer Science (8531).

Naismith, L., et al., (2004). Literature review in mobile technologies and learning. UK: Futurelab.

Neto, H., et al., (2014). Visual Communication Panels for Production Control using Gamification Techniques. In: Proc. 22nd Ann. Conf. of the Int'l. Group for Lean Construction. Oslo, Norway

O’Donovan, S., Gain, J., Marais, P., (2013): A Case Study in the Gamification of a University-level Games Development Course. In: Proceedings of the South African Institute for 
gamification into e-learning in higher Education, $7^{\text {th }}$ world conference on Education Sciences, (WCES2015), Athens. Greece.

Villagrasa, S., Fonseca, D., and Redondo, E., (2014). Teaching Case of Gamification and Visual Technologies for Education. Journal of Cases on Information Technology, $16(4), 38-57$

Walker, et al, (2011). Visual Thinking: Art Students Have an Advantage in Geometric Reasoning. Creative Education. 2(2). 22-26.

Werbach, K., Hunter, D., (2012). For the win. How game thinking can revolutionize your business. Wharton Digital Press, Philadelphia, PA. the Learning Sciences. A Global Cities Education Network Report. New York, Asia Society. Retrieved from:

https://www.aare.edu.au/data /publications/2012/Saavedra1 2.pdf. On:2/2/2019.

Sailer et al. (2013). Psychological Perspectives on Motivation through Gamification. Interaction Design and Architecture(s) Journal. (19). 28-37.

Sandusky, S. (2017). Gamification in Education. University of Arizona. United States. Retrieved from: http://hdl.handle.net/10150/5 56222. On/; 1/1/2019.

Smith, P. \& Ragan, T. (2005). Instructional Design. (3rd ed). New York: Merill.

Urh, M., et al., (2015). The model for introduction of 